UNIVERSIDADE DE SÃO PAULO

FACULDADE DE FILOSOFIA, LETRAS E CIÊNCIAS HUMANAS DEPARTAMENTO DE SOCIOLOGIA PROGRAMA DE PÓS-GRADUAÇÃO EM SOCIOLOGIA

JESUS VASQUEZ MEIRA PEREZ JUNIOR

\title{
A expropriação psicológica do sujeito no capitalismo tardio e a concepção neurocientífica de homem
}

Versão corrigida 


\section{JESUS VASQUEZ MEIRA PEREZ JUNIOR}

\section{A expropriação psicológica do sujeito no capitalismo tardio e a concepção}

neurocientífica de homem

Versão corrigida

Dissertação apresentada ao Programa de Pós-Graduação em Sociologia da Faculdade de Filosofia, Letras e Ciências Humanas da Universidade de São Paulo, como requisito para obtenção do título de Mestre em Sociologia, sob orientação do Prof. Dro ${ }^{\circ}$ Ricardo Musse.

\footnotetext{
Versão corrigida
}

São Paulo

2018 
Autorizo a reprodução e divulgação total ou parcial deste trabalho, por qualquer meio convencional ou eletrônico, para fins de estudo e pesquisa, desde que citada a fonte.

Catalogação na Publicação

Serviço de Biblioteca e Documentação

Faculdade de Filosofia, Letras e Ciências Humanas da Universidade de São Paulo

P 438 e

Perez Junior, Jesus Vasquez Meira

A expropriação psicológica do sujeito no

capitalismo tardio e a concepção neurocientífica de

homem / Jesus Vasquez Meira Perez Junior ;

orientador Ricardo Musse. - São Paulo, 2018.

$114 \mathrm{f}$.

Dissertação (Mestrado) - Faculdade de Filosofia,

Letras e Ciências Humanas da Universidade de São

Paulo. Departamento de Sociologia. Área de

concentração: Sociologia.

1. Teoria Crítica. 2. Sociologia do Conhecimento. I. Musse, Ricardo, orient. II. Título. 


\section{ENTREGA DO EXEMPLAR CORRIGIDO DA DISSERTACÃO/TESE}

\section{Termo de Ciência e Concordância do (a) orientador (a)}

Nome do (a) aluno (a): Jesus Vasquez Meira Perez Junior

Data da defesa: 05/03/2018

Nome do Prof. (a) orientador (a): Ricardo Musse

Nos termos da legislação vigente, declaro ESTAR CIENTE do conteúdo deste EXEMPLAR CORRIGIDO elaborado em atenção às sugestões dos membros da comissão Julgadora na sessão de defesa do trabalho, manifestando-me plenamente favorável ao seu encaminhamento e publicação no Portal Digital de Teses da USP.

São Paulo, 15 de agosto de 2019

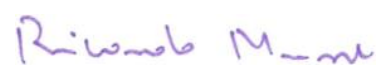


PEREZ-JUNIOR, JESUS VASQUEZ MEIRA. A expropriação psicológica do sujeito no capitalismo tardio e a concepção neurocientífica de homem. Dissertação apresentada à Faculdade de Filosofia, Letras e Ciências Humanas da Universidade de São Paulo para obtenção do título de Mestre em Sociologia.

Aprovado em:

Banca Examinadora

Prof (a). Dr (a).: Instituição:

Julgamento: Assinatura:

Prof (a). Dr (a).: Instituição:

Julgamento: Assinatura:

Prof (a). Dr (a).: Instituição:

Julgamento: Assinatura:

Prof (a). Dr (a).: Instituição:

Julgamento: Assinatura: 
A meu filho Vicente, minha única construção ao mesmo tempo plena e prenhe de sentido. 


\section{AGRADECIMENTOS}

Agradeço ao Prof. Dr. Ricardo Musse, meu orientador, cujos cursos de graduação direcionaram de maneira decisiva minhas preocupações teóricas, assim como lhe agradeço por ter aceitado me orientar com um tema de pesquisa não muito convencional, e por tê-lo feito de maneira nada invasiva e massacrante, o que, obrigome a dizer, não costuma ser a regra.

Agradeço do mesmo modo ao Prof. Dr. José Leon Crochík, por ter me aceitado em seus cursos de graduação no Instituto de Psicologia da Universidade de São Paulo, cursos esses que foram decisivos em minha curta, humilde, porém pessoalmente significativa trajetória acadêmica.

Devo um agradecimento especial também à Prof. Dra. Maria Helena OlivaAugusto, minha orientadora na Iniciação Científica, docente sempre disponível, de quem o tratamento delicado para com os discentes e a sensibilidade às particularidades de cada um deles eu recordo até hoje. O impacto de sua preocupação, de longa data, em tratar sociologicamente o tema da individualidade está na base dos interesses que desenvolvi como sociólogo.

Agradeço ao Prof. Dr. Odair Sass pelo interesse em compor a Banca ao lado dos docentes acima citados.

Agradeço ao meu avô, José Januário (in memorian), e à minha avó, Cecilia (in memorian), por todo o amor e o cuidado.

Agradeço a meu pai, um exemplo e um companheiro inseparável nos últimos tempos, demasiadamente difíceis, mas alargadores da minha experiência.

Agradeço à minha mãe, pelo cuidado e carinho de sempre, e também pelo exemplo de perseverança.

Agradeço à minha irmã Janayna, ao meu cunhado João Henrique (vulgo Kiko) e aos meus sobrinhos Ananda e Raul, pelo apoio que deram a mim e a meu filho em tempos passados, apoio com efeitos até hoje.

Agradeço a César Niemietz, companheiro na preparação para a seleção do mestrado, como também em todas as etapas concluídas até o presente momento. Por 
além de compartilhar a perplexidade frente às agruras e às incoerências da vida acadêmica, pela amizade e parceria na luta pela vida - essa sim, implacável.

À Mayra Fontebasso e Natália Natarelli, pela leitura do texto de qualificação.

À Elaine Monteiro Ávila, pelo auxílio com os ajustes finais e, sobretudo, pelo amor e companheirismo.

Às educadoras da Creche Central da Universidade de São Paulo, especialmente Janeide de Souza Silva, Maria Claudia, Lia, Sthefanie, Juliana, Dina, Fran, Priscila e Beth. Concebi o projeto que agora termina em dissertação quando meu filho ainda frequentava essa instituição ímpar, que hoje resiste aos desmandos do reitor graças à atitude combativa de parte dessas educadoras. Sem esse auxílio, sequer teria me graduado.

Agradeço também a Flávia Ranoya, Daniela Teperman, Rejane Rubino, Cristiani Fanti e Délia Maria De Césaris, pessoas com quem nunca tive relação acadêmica, e que sequer conheceram esta pesquisa em qualquer uma de suas etapas, mas cujas relações cotidianas de algum modo também têm seu lugar neste trabalho, mesmo que muito indiretamente.

Agradeço a Vicente, meu filho, por deixar claro a cada dia o quanto as preocupações relativas ao tema desta dissertação são legítimas e socialmente necessárias, ainda que meu empenho em tê-las trabalhado não tenha tido o alcance e a profundidade que sempre desejei que tivesse.

Agradeço a Gustavo, pela prontidão e gentileza com que sempre me atendeu na secretaria do departamento.

Agradeço à CAPES pelo auxílio financeiro sem o qual não teria sido possível dedicar-me a este trabalho. 
[...]

A gente se acostuma para não se ralar na aspereza, para preservar a pele. Se acostuma para evitar feridas, sangramentos, para esquivar-se de faca e baioneta, para poupar o peito. A gente se acostuma para poupar a vida. Que aos poucos se gasta, e que, gasta de tanto acostumar, se perde de si mesma.

Marina Colasanti, Eu sei mas não devia.

[...] a vida tornou-se ideologia de sua própria ausência.

Theodor Adorno, Minima Moralia. 


\section{RESUMO}

PEREZ-JUNIOR, JESUS VASQUEZ MEIRA. A expropriação psicológica do sujeito no capitalismo tardio e a concepção neurocientífica de homem. Dissertação (Mestrado). Faculdade de Filosofia, Letras e Ciências Humanas, Universidade de São Paulo, 2017.

Esta dissertação tem como objetivo analisar sociologicamente a recente ascensão da concepção neurocientífica de homem, tentando compreender e evidenciar em que medida ela está entrelaçada a certos aspectos da sociedade capitalista tardia, sobretudo ao estatuto do sujeito a partir da segunda metade do século XX. Por um lado me preocupo em compreender a gênese da concepção neurocientífica de homem no campo da ciência; por outro, em lançar alguma luz sobre o seu sucesso cultural, o que implica, inevitavelmente, o questionamento acerca da aceitação dessa visão reducionista de homem pelos próprios sujeitos. A hipótese que busco desenvolver é a de que o sucesso vertiginoso e a estabilidade da concepção neurocientífica de homem (seja no campo restrito da ciência, seja no imaginário social) são um sintoma atual - entre muitos outros, incontáveis - do declínio da subjetividade contemporânea, efeito, por sua vez, do atual estado da civilização Ocidental e de sua marcha contraditória rumo ao progresso.

Palavras-chave: Teoria crítica da sociedade; Escola de Frankfurt; Neurociências; Psicanálise; Cerebralização; Naturalização; Reificação; 


\begin{abstract}
PEREZ-JUNIOR, JESUS VASQUEZ MEIRA. The psychological expropriation of subject in late capitalism and the neuroscientific conception of man. Dissertação (Mestrado). Faculdade de Filosofia, Letras e Ciências Humanas, Universidade de São Paulo, 2017.
\end{abstract}

This dissertation aims to analyze in a sociological fashion the recent rise of the neuroscientific conception of mankind, while trying to understand and demonstrate in which stage it is intertwined with certain aspects of the late capitalist society, especially the status of the subject from the second half of the twentieth century. On the one hand I care to understand the genesis of the neuroscientific conception of mankind in the field of science; on the other hand, to shed some light on their cultural success, which inevitably implies the questioning on the acceptance of this reductionist view of mankind by the subjects themselves. The hypothesis I seek to develop is that the vertiginous success and stability of the neuroscientific conception of mankind (whether in the restricted field of science or in the social imaginary field) is a current symptom among many others, countless - of the decline of contemporary subjectivity as an outcome caused by the present state of Western civilization and its contradictory march towards progress.

Keywords: Critical theory of society; Frankfurt School; Neurosciences; Psychoanalysis; Cerebralization; Naturalization; Reification. 


\section{SUMÁRIO}

$\begin{array}{ll}\text { Introdução } & 12\end{array}$

Observação preliminar: a secular história do cérebro. 18

Capítulo 1 - A concepção de homem das neurociências 22 e a cerebralização do sujeito

O problema de pesquisa

Olhares sociológicos existentes e algumas críticas

Capítulo 2 - A expropriação psicológica do sujeito no capitalismo tardio e o sucesso da concepção neurocientífica de homem

A dialética da racionalização e a expropriação

psicológica do sujeito no capitalismo tardio

O estudo objetivo da mente como correspondente cognitivo do processo histórico de expropriação psicológica do sujeito: da cibernética e das ciências cognitivas às neurociências

A concepção neurocientífica de homem e seu sucesso como efeitos da reificação da sociedade e do sujeito: crítica do conhecimento é crítica da sociedade e vice-versa

Capítulo 3 - A crítica dos possíveis efeitos sociais, políticos e psíquicos do sucesso da concepção neurocientífica de homem

O programa forte das neurociências e a produção de selves-objetivos

A cerebralização do autismo e da depressão:

casos para se pensar a reificação e a desresponsabilização dos sujeitos

A liquidação do sujeito pela cerebralização:

desresponsabilização subjetiva, submissão e identificação à realidade

Considerações finais 


\section{Introdução}

Por isso, é surpreendente que numerosas especulações biológicas sobre o espírito efetuem um passo a mais que, na minha concepção, é um passo demais. Precisemos: um passo que pula da necessária neutralização metodológica do social à cegueira conceitual; o ser abordado segundo o corpo sendo frequentemente assimilado, implícita ou explicitamente, ao ser considerado em sua totalidade. O passo demais é um erro, ao mesmo tempo lógico e antropológico, que remete à questão das relações entre o sujeito humano e seu corpo, entre o todo e a parte.

Alain Ehrenberg, O Sujeito Cerebral, 2009.

É fato que nas últimas décadas do século XX e no início do século XXI, o homem vem sendo vislumbrado sobremaneira a partir de sua condição biológica, a despeito de suas condições psíquica e sociológica, também determinantes de seus modos de vida e de ser, ainda que tais determinações venham sendo ora negligenciadas, ora negadas com afinco.

Em 1953, James Watson e Francis Crick descobriram o modelo em dupla hélice do DNA, alavancando o progresso vertiginoso da biologia molecular; cinquenta anos depois, em 2003, o genoma humano foi sequenciado, ocasião que suscitou, alimentou e continua a alimentar uma febre de anseios relacionados à cura de inúmeras doenças, síndromes e transtornos e à possibilidade de, por meio de intervenções genéticas, agir sobre problemas inequivocamente sociais, como a criminalidade e o sofrimento mental.

No que tange ao domínio da subjetividade, o ponto de apoio indiscutível das teorias biológicas tem sido um órgão certamente indispensável a qualquer indivíduo, mas nem por isso integralmente determinante de sua existência e de seu desenvolvimento subjetivo: o cérebro - os neurônios que o formam, os hormônios que regulam o seu funcionamento e os impulsos elétricos pelos quais opera. Tratando-se do sujeito, as neurociências ${ }^{1}$ se tornaram paradigmáticas, tendo ascendido sobre as diversas disciplinas da área de humanas e sobre o campo das disciplinas psi.

\footnotetext{
${ }^{1}$ Devido a seu caráter multidisciplinar, o termo neurociência muitas vezes aparece no plural em livros, revistas e jornais. Por outro lado, parece que pelo fato de as diferentes disciplinas constituintes (física, matemática, biologia molecular, fisiologia, medicina, psicologia, etc.) compartilharem uma mesma
} 
Acredita-se que a mente, os mais variados tipos de sofrimento mentais, a violência, o amor, a religiosidade ou a moralidade hão de ser explicados a partir da configuração e do funcionamento do cérebro, pois não restam dúvidas de que dele resultam diretamente. Para os que compartilham da visão naturalista da subjetividade, a confirmação dessa hipótese de trabalho não passa de uma questão de tempo. Nessa toada, muitos projetos milionários de mapeamento cerebral foram concebidos, acreditando-se que, com isso, os mistérios da subjetividade serão desvendados de uma vez por todas. Esse pensamento caracteriza o que o sociólogo Alain Ehrenberg denominou como programa forte de neurociências - que identifica conhecimento do cérebro ao conhecimento de si, espera poder fundir a psiquiatria e a neurologia e criar meios eficazes de atuar sobre o cérebro para aumentar nossas capacidades de agir e decidir. É essencialmente desse programa que este trabalho trata.

O flerte grosseiro e perigoso com o reducionismo, a superficialidade e a precipitação desta crença são evidentes, seja qual for o ângulo a partir do qual a olhamos; assim como são flagrantemente preguiçosas e, ao mesmo tempo, apressadas as constatações e "descobertas" neurocientíficas sobre os mais variados aspectos da vida humana, de tal modo que não se pode prontamente concordar com elas. O problema é que a ideia neurocientífica de homem que está na base do programa forte, em vez de ser tratada como o que de fato é, uma aposta metodológica, é tomada como algo pura e simplesmente real. Portanto, não basta apenas negá-la de pronto, é necessário esclarecêla discutindo sua essência e seu lastro social, demonstrando que boa parte das considerações neurocientíficas alardeadas pelos diversos meios de comunicação são antes "teses eminentemente filosóficas, mais do que hipóteses científicas"2.

Cabe sofisticar nossa desconfiança de modo a elucidar que aqui não se trata de propor tabula rasa, inobservância ou a negação dogmática do conhecimento neurocientífico, com potencial esclarecedor evidentemente bem-vindo e de fundamental importância, mas sim de alertar para os seus exageros, atropelos, para a sua imprudência, sua parcela ideológica - que se revela facilmente quando a abordagem cerebral se desloca para fenômenos indecifráveis (porque complexos) sem que se leve

hipótese fundamental - a da centralidade do cérebro para sermos o que somos -, em muitas ocasiões o termo aparece no singular. No geral, optei pelo termo no plural.

${ }^{2}$ EHRENBERG, Alain. O sujeito cerebral. Psicologia Clínica, Rio de Janeiro, vol.21, 2009, p. 194. 
em conta os âmbitos social, cultural e psíquico de nossa existência, os quais são deliberadamente obliterados da análise naturalista.

Jurandir Freire-Costa condensa isso de modo irretocável:

\begin{abstract}
Não se trata, portanto, de recusar, de maneira cega e dogmática, os promissores avanços da tecnociência; trata-se de afirmar que nada disso faz do cérebro a sede autárquica do mental, como pretende o fisicalismo redutivista.

O cérebro é um elo na cadeia que liga o corpo ao ambiente/mundo. Sua higidez, obviamente, é uma condição necessária à gênese e ao equilíbrio das atividades mentais. Mas o mesmo poderia ser dito do restante da matéria corporal e do ambiente. $\mathrm{O}$ corpo do sujeito não é um apêndice diluído do cérebro, assim como o ambiente não é a contração gramatical de estímulos atomizados por aparatos teóricos e instrumentais. Não conhecemos sujeitos nascidos de cérebros em cuba, assim como não conhecemos sujeitos com corpo e mundo, mas desprovidos de cérebro. ${ }^{3}$
\end{abstract}

Dito isso, o objetivo da minha pesquisa de mestrado é duplo: a um só tempo pretendo analisar sociologicamente algumas das condições de emergência e, sobretudo, de proeminência da concepção neurocientífica de homem, bem como criticá-la, tendo em vista tanto aquilo que possui de irrefletido acerca de si mesma, quanto o que revela de regressivo acerca da sociedade contemporânea.

Assim sendo, por um lado acho justo e oportuno questionar, de um ponto de vista ao mesmo tempo histórico e sociológico, o que fundamenta essa maneira de ver o homem. De outro lado, há que se indagar o que escapa a ela, o que ela e seu sucesso cultural - haja vista sua ampla aceitação para além das paredes dos laboratórios objetivamente revelam sobre a sociedade contemporânea, o que denunciam acerca das atuais condições de formação dos sujeitos, e que tipo de efeitos podem advir de sua ampla aceitação por parte das pessoas.

Parto, em ambos os casos, de um pressuposto suficientemente claro, que por ora pode ser apresentado sem maiores detalhes, a saber: que as representações, as imagens, toda a sorte de teorias (teológicas, filosóficas, científicas) acerca do cosmos, da sociedade, da natureza, do homem etc., guardam relações com os homens concretos, em seus modos de vida historicamente engendrados:

\footnotetext{
${ }^{3}$ FREIRE-COSTA, Jurandir. O risco de cada um: e outros ensaios de psicanálise e cultura. Rio de janeiro: Garamond, 2007, p.19-20.
} 
A produção de ideias, de representações, da consciência, está, de início, diretamente entrelaçada com a atividade material e com o intercâmbio material dos homens, como a linguagem da vida real. O representar, o pensar, o intercâmbio espiritual dos homens, aparecem aqui como emanação direta de seu comportamento material. O mesmo ocorre com a produção espiritual, tal como aparece na linguagem da política, das leis, da moral, da religião, da metafísica etc. de um povo. Os homens são os produtores de suas representações, de suas ideias etc., mas os homens reais e ativos, tal como se acham condicionados por um determinado desenvolvimento de suas forças produtivas e pelo intercâmbio que a ele corresponde até chegar às suas formações mais amplas. A consciência jamais pode ser outra coisa do que o ser consciente, e o ser dos homens é o seu processo de vida real. E se, em toda ideologia, os homens e suas relações aparecem invertidos como numa câmera escura, tal fenômeno decorre de seu processo histórico de vida, do mesmo modo por que a inversão dos objetos na retina decorre de seu processo de vida diretamente físico ${ }^{4}$.

A concepção sociológica que me orienta é a da Teoria crítica da sociedade, especificamente os pensamentos de Max Horkheimer e Theodor Adorno a respeito da relação entre sociedade, cultura (que engloba o campo da ciência) e formação subjetiva, bem como o diagnóstico do presente histórico concebido por ambos, inicialmente na década de 1940 (porém discutido e realçado em muitos de seus aspectos até o fim da década de 1960): o de que o progresso da racionalização que culminou na sociedade capitalista tardia ${ }^{5}$, ao invés de promover o desenvolvimento acentuado da subjetividade, contraditoriamente vinha tendo como efeito a sua liquidação, o declínio do indivíduo, como aludiu Max Horkheimer em Eclipse da Razão $o^{6}$.

Desse modo, compreendo que a concepção neurocientífica de homem esteja inextricavelmente enredada às condições históricas da individualidade em seu mais recente capítulo, isto é, às atuais condições de formação dos sujeitos. Portanto, de modo mais esmiuçado, esta dissertação tem como objetivo analisar sociologicamente a atual

\footnotetext{
${ }^{4}$ MARX, Karl; ENGELS, Friedrich. A ideologia alemã. São Paulo: Editorial Grijalbo, 1977, p. 36-37.Cf. HORKHEIMER, Max. Teoria tradicional e Teoria crítica. São Paulo: Abril Cultural, 1975[1937], p. 3536.Coleção Os Pensadores, v.48.

${ }^{5}$ Capitalismo posterior às teorizações de Karl Marx, o qual se forja a partir da década de 1930, após aquebra da Bolsa de Nova Iorque, e se desenvolve de forma pujante na segunda metade do século XX, após a Segunda Guerra Mundial. Por um lado, o uso da expressão deve-se à intenção de reafirmar que a sociedade do pós-guerra é essencialmente capitalista assim como a analisada por Marx; por outro lado, o termo tardio busca dar conta da passagem do tempo, sugerindo a transformação qualitativa do capitalismo, o qual, com a recente supremacia das relações de produção sobre as forças produtivas, tornou-se mais plástico, mais imune a crises tanto econômicas quanto ideológicas, haja vista o crescente caráter administrativoda sociedade incidir até nas profundezas da constituição psíquica dos sujeitos. (Cf. ADORNO, Theodor. Sociedade industrial ou Capitalismo tardio. Em: Coleção Grandes Cientistas Sociais: Textos escolhidos. São Paulo: Editora Ática, 1986 [1968]).

${ }^{6}$ Cf. HORKHEIMER, Max. Eclipse da Razão. São Paulo: Unesp, 2015 [1947].
} 
cerebralização do sujeito pela teoria neurocientífica, tentando compreender e evidenciar em quê medida ela está entrelaçada a certos aspectos da sociedade capitalista tardia, sobretudo ao estatuto do sujeito a partir da segunda metade do século XX.

A hipótese que busco desenvolver é a de que o sucesso vertiginoso e a estabilidade da concepção neurocientífica de homem são um sintoma atual - entre muitos outros, incontáveis - do declínio da individualidade contemporânea, fruto, por sua vez, do atual estado da civilização Ocidental e de sua marcha rumo ao progresso. Por conseguinte, a ideia é a de que a concepção neurocientífica de homem, produzida cientificamente, difundida culturalmente e aceita subjetivamente é resultado de amplos processos históricos e sociais; trata-se de um epifenômeno, uma ideologia. Ela é antes de tudo efeito, e não causa direta da liquidação do sujeito, não obstante, a concepção neurocientífica de sujeito contribua para esta liquidação, retroalimentando-a, ratificando-a. Pois sendo efeito, sua crítica deve extrapolá-la, ir além dela, de modo a alcançar as suas causas e os seus fundamentos.

Nesse sentido, proponho uma abordagem crítica das neurociências e de sua figura de homem que adota como referência a Teoria crítica da sociedade de Theodor Adorno e Max Horkheimer, uma vez que julgo possível identificar na problematização que tais autores fazem da racionalização da sociedade e do conhecimento, assim como do movimento histórico da individualidade inextricavelmente vinculado ao tema da racionalização, elementos que tornam profícua uma tentativa de interpretação do processo de cerebralização em curso e de seu respectivo sucesso e, mais do que isso, que fundamentam um juízo acerca de seus limites e omissões, atrativos e perigos.

No capítulo I, apresento a visão que as neurociências têm do homem, recorrendo às obras de neurocientistas renomados e a materiais difundidos tanto em revistas de circulação restrita quanto naquelas voltadas para o público em geral, como também me sirvo de trabalhos antropológicos, filosóficos e sociológicos que tratam da questão. Ali delimito o problema da pesquisa e discuto os escassos enfoques sociológicos dados ao tema, apresentando a partir deles o meu modo de colocar o problema.

No segundo capítulo discuto a relação entre o progresso da racionalidade e o declínio da subjetividade no capitalismo tardio, demonstrando de que maneira esse movimento histórico paradoxal está no cerne do sucesso científico e cultural da concepção de sujeito da neurociência. Argumento que há um paralelo, uma 
correspondência entre o empobrecimento da subjetividade na vida efetiva e o surgimento de uma concepção de sujeito igualmente pobre no campo da ciência, estando a recepção subjetiva positiva dessa concepção "científica" de homem apoiada, do mesmo modo (e mais uma vez!), na fragilidade e na impotência da individualidade na sociedade contemporânea.

No capítulo III estabeleço algumas críticas a respeito dos efeitos políticos, sociais e psíquicos da aceitação de tal concepção pelos sujeitos. No limite, pode-se dizer que a aceitação da visão de um "sujeito cerebral" conduz a um quadro subjetivo regressivo, calcado na renúncia a lidar com a própria subjetividade e com o mundo, no conformismo ante uma realidade social que abafa e sufoca, em que postar-se afirmativamente como sujeito, como um $E u$, tem custos sociais e psíquicos altos que parcela considerável das pessoas não se dispõe ou sequer tem meios para se dispor a pagar. Nesse sentido, a cerebralização do sujeito surge como um atestado de falência da subjetividade na sociedade contemporânea. 


\section{Observação preliminar: a secular história do cérebro.}

Tendo como objetivo discutir a recente ascensão das neurociências e sua figura cerebral de homem, tanto na esfera do conhecimento quanto na esfera ampliada da cultura, cumpre dizer algo que talvez não seja óbvio: a preocupação com a relação entre corpo e alma, mais recentemente tratada como sendo entre cérebro e mente, não é novidade de nossa época.

A discussão sobre o cérebro se insere, de certa maneira, no debate mais amplo acerca da relação entre corpo e alma, controvérsia filosófica e fisiológica que remonta a nomes distantes como Hipócrates (460 a. C. - 377 a. C.), Aristóteles (384 a. C. - 322 a.C.), Claudio Galeno (130 d. C.), Santo Agostinho (354-430), São Tomás de Aquino (1225 - 1274), René Descartes (1596-1650), Thomas Willis (1621-1675), John Locke (1632-1704), Nicolas Malebranche (1638-1715), Gottfried Wilhelm Leibniz (16461716) ${ }^{7}$, Santiago Ramon y Cajal (1852-1934), Sigmund Freud (1956-1939) entre outros.

Desde a Antiguidade a relação entre corpo (matéria) e mente (alma, espírito, etc.) é alvo de especulações, há séculos havendo quem tenha se esforçado para relacionar ou mesmo identificar certos comportamentos humanos a determinados traços ou estados corporais.

Entre tais esforços, talvez o exemplo mais conhecido da importância concedida ao cérebro na discussão sobre o sujeito seja o da Frenologia do médico vienense Franz Joseph Gall (1758-1828), que compreendia o cérebro como o órgão da mente. A mente seria formada por capacidades inatas; cada capacidade teria sua própria localização no cérebro e quanto maior a respectiva capacidade, maior seria o tamanho da região cerebral correspondente. Como o crânio deve sua forma ao cérebro, a partir da análise de suas protuberâncias, Gall acreditava ser possível descobrir as aptidões e as inclinações individuais. A Frenologia seria esse exame craniano capaz de revelar o caráter e as habilidades das pessoas. Embora tenha sido relegada ao ostracismo, a teoria

\footnotetext{
${ }^{7}$ Cf. VIDAL, Fernando. O sujeito cerebral: um esboço histórico e conceitual. Polis e Psique, v.1, n.1, p.169-190, 2011.
} 
de Gall gozou de grande popularidade no século XVIII ${ }^{8}$ (influenciou, por exemplo, o famoso criminologista Cesare Lombroso).

Para Sérgio Paulo Rouanet, por sua vez, o médico Julien Offray de La Mettrie (1709-1751) "é o ancestral do materialismo biologizante que ocupa o centro do debate contemporâneo"9, no que o ensaísta não está só, já que para o lúcido neurocientista Gérard Percheron, desde La Mettrie "a explicação do cérebro como uma máquina tem sido o motor duma redução materialista dos fenômenos psicológicos" ${ }^{\prime 10}$.

Em sua obra mais famosa, $O$ homem-máquina, La Mettrie radicalizou Descartes, que julgava que os animais não tinham alma e, portanto eram como máquinas, estendendo tal observação para a realidade dos seres humanos, que em tudo eram próximos dos animais e, portanto, também não possuíam alma ${ }^{11}$. O que conhecemos por "alma" seria, para ele, "um princípio também material, localizado no cérebro" 12 , que conduz nosso organismo e nos possibilita pensar. Para La Mettrie, os homens, por conseguinte, “eram meras máquinas, conjuntos de engrenagens puramente materiais, sem nenhuma substância espiritual" $"$.

Ainda segundo Rouanet, La Mettrie seria apenas o ponto de partida de uma corrente intelectual iluminista que concedeu importância ímpar ao corpo. De acordo com Sérgio Paulo, a Ilustração gestou duas grandes linhagens intelectuais:

Uma tem sua origem em pensadores como Diderot, Helvétius, Holbach. Para eles, o homem é determinado pelo meio, e consequentemente a mudança das relações sociais pode modificar suas condições de existência. Essa linhagem prolongou-se nos séculos XIX e XX nos utilitaristas, como Jeremy Bentham, e nos liberais, como Stuart Mill, para os quais um homem novo pode ser produzido pela legislação e pela educação, bem como os marxistas, para os quais ele pode ser produzido pela revolução social.

\footnotetext{
${ }^{8}$ Cf. VIDAL, Fernando. O sujeito cerebral: um esboço histórico e conceitual. Polis e Psique, v.1, n.1, 2011, p.180; ORTEGA, Francisco e BEZERRA JR., Benilton. O sujeito cerebral, Viver Mente e Cérebro, v. 162, 2006, p.16-17.

${ }^{9}$ Cf. ROUANET, Sérgio Paulo. O homem-máquina hoje. Em: O Homem-Máquina: a ciência manipula o corpo. Org.: Adauto Novaes. São Paulo: Companhia das Letras, 2003.

${ }^{10}$ PERCHERON, Gérard. Neuromitologias: cérebro, indivíduo, espécie e sociedade. In: VEYNE, Paul et al. Indivíduo e Poder. Lisboa: Edições 70, 1987, p. 138.

${ }^{11}$ ROUANET, Sérgio Paulo. O homem-máquina hoje. Em: O Homem-Máquina: a ciência manipula o corpo. Org.: Adauto Novaes. São Paulo: Companhia das Letras, 2003, p. 38.

${ }^{12}$ Ibidem, p. 48-49.

${ }^{13}$ Ibidem, p. 38.
} 
A outra linhagem parte de La Mettrie. Ela acredita que o organismo determina o essencial da vida do homem. É tão eudemonista quanto a primeira linhagem, mas acha que a felicidade deve ser buscada no bom funcionamento do corpo, e não na transformação social. A linhagem de La Mettrie prosseguiu no darwinismo social, e no uso dos biopoderes, segundo Foucault, na tentativa de provocar a docilidade social pela ação sobre os corpos. ${ }^{14}$

A primeira linhagem, depois de dois séculos de domínio, parece estar cedendo lugar à segunda, a qual continua tendo como ideal um novo homem que, agora, em vez de ser um produto da sociedade, deve ser antes fabricado no laboratório ${ }^{15}$.

Também é possível encontrar a tentativa de relacionar mente e cérebro em um passado não tão distante quanto o do século das luzes, como no Projeto para uma psicologia científica (1895) de Sigmund Freud ${ }^{16}$ (em sua fase pré-psicanálise) ou nas cautelosas esperanças registradas em autobiografia de Santiago Ramon y Cajal (fisiologista espanhol que descobriu os neurônios) ${ }^{17}$, para quem os neurônios eram "as borboletas da alma".

Tais "recordações" são, por ora, suficientes para evidenciar que a tentação de cerebralização do sujeito não é algo apenas de nosso tempo - como já exposto, a novidade reside tanto alcance da aceitação da concepção cerebral de homem que logrou a neurociência contemporânea quantona abrangência de seus perversos efeitos políticos, sociais e psíquicos.

Se a ideia genérica de um sujeito cerebral deve, antes de ser produto inédito dos avanços da atual ciência do cérebro, ser o seu pressuposto (dadas as iniciativas anteriores de relacionar cérebro e sujeito) ${ }^{18}$, desde já cabem algumas perguntas: por que apenas recentemente uma concepção cerebral de sujeito prevaleceu entre nós? O que houve de lá para cá? Quais fatores impediram que outras concepções vingassem nos séculos passados? Por que prevalece hoje? Por que agora?

\footnotetext{
${ }^{14}$ ROUANET, Sérgio Paulo. O homem-máquina hoje. Em: O Homem-Máquina: a ciência manipula o corpo. Org.: Adauto Novaes. São Paulo: Companhia das Letras, 2003, p. 40.

${ }^{15}$ Ibidem, p.40.

${ }^{16}$ Cf. FREUD, Sigmund. Projeto para uma psicologia científica. Em: Obras psicológicas completas de Sigmund Freud. Rio de Janeiro: Imago, 1990 [1895].

${ }^{17}$ Cf. RAMON Y CAJAL, Santiago. Recollections of my life. Massachussets: MIT Press, 1996 [1917].

${ }^{18}$ Cf. ORTEGA, Francisco e BEZERRA JR., Benilton. O sujeito cerebral, Viver Mente e Cérebro, v.162, 2006, p.16-17.
} 
Observa-se, pois, a ocorrência de algumas tentativas de relacionar o cérebro com as ideias e os comportamentos dos homens ao longo da história até que isso se firmasse hoje, tornando-se algo tautológico para aqueles que o aceitam sem mais. Para mim, o golpe de misericórdia se iniciou em meados do século XX, no seio de uma sociedade em que o sujeito efetivo começou a experimentar seu declínio ante a densa, complexa e impenetrável cadeia de relações, funções e privações resultante da intensificação do processo de racionalização social que se impunha a ele, ao mesmo tempo em que, como aspecto do mesmo processo (de racionalização), o estudo "objetivo" de tudo, inclusive da subjetividade, erigiu-se como norma.

Os próximos capítulos desta história se encontram, pouco antes do estabelecimento da neurociência contemporânea na década de 1970, no advento da cibernética e do campo das ciências cognitivas, entre as décadas de 1940 e 1950, mesmo período em que, também nos Estados Unidos, Max Horkheimer e Theodor Adorno (intelectuais alemães emigrados), elaboravam um diagnóstico radical acerca do estágio da Civilização Ocidental e das vicissitudes do sujeito nela inserido. Tanto a cibernética e as ciências cognitivas (campo integrado pelas neurociências) quanto os frankfurtianos falaram-nos de um mesmo homem. Explorarei essa "curiosidade", esse paralelismo histórico, no capítulo II, depois de demonstrar como tem se manifestado culturalmente a concepção de homem das neurociências contemporâneas. 


\section{Capítulo 1}

\section{A concepção de homem das neurociências e a cerebralização do sujeito}

Um belo dia, no fim do século passado, o homem mudou. Considerado à luz da Psicanálise ou da Antropologia Cultural havia cerca de trinta anos, estava sujeito ao peso das estruturas, era determinado pelas condições sociais e familiares, governado por desejos inconscientes, dependente da história, da cultura e da língua [...]. Esse homem das Ciências Humanas e Sociais que, em meados do século, florescia no paradigma estruturalista de Lévi-Strauss, Benveniste ou Lacan, e ainda triunfava em Bourdieu, esse homem desapareceu furtivamente da paisagem. Novas ciências falavam-nos de um novo homem. Eram as neurociências [...]

Francis Wolff, Nossa humanidade: de Aristóteles às Neurociências, 2013.

Ao longo destes capítulos, o leitor ter-se-á rendido à evidência de que o cérebro do homem é constituído por milhões de neurônios ligados entre si por uma imensa rede de cabos, de que nos seus "filamentos" circulam impulsos elétricos ou químicos inteiramente explicáveis em termos moleculares ou físico-químicos e de que qualquer comportamento se explica pela mobilização interna de um conjunto topologicamente definido de células nervosas.

Jean Pierre-Changeux, O Homem Neuronal, 1991.

[...] uma fórmula da depressão é equivalente ao nível de 3-metoxi-4hidroxifenilglicol (um composto encontrado na urina de todas as pessoas e aparentemente não afetado pela depressão), menos o nível de 3-metoxi-4 ácido hidroximandélico, mais o nível de norepenefrina, menos o nível de normetanefrina mais o nível de metanefrina; o resultado disso é dividido pelo nível de 3-metoxi-4 ácido hidromandélico, mais uma variável de conversão inespecificada; ou como o Comprehensive Textbook of Psychiatry coloca: "escore tipo-D = c1 (MHPG) - c2 (VMA) + c3 (NE) - c4 (NMN + MN) / VMA + Co." 


\section{0 problema de pesquisa}

Trancuilo Tezoto caminhou lentamente até uma fileira de cadeiras pretas. Acomodou-se em uma delas, dobrou o corpo, descalçou os sapatos e as meias, tirou um par de sandálias de borracha de uma sacola de plástico e as ajeitou nos pés. Endireitou o corpo, tirou a dentadura e a aliança e as entregou a sua mulher, Inês, para que as guardasse. Recostou a cabeça na parede e respirou fundo, como se aquela operação banal the tivesse custado um esforço sobre-humano. Há quase cinco meses, duas vezes por semana, o metalúrgico aposentado Trancuilo Tezoto repete o mesmo ritual. Aos 69 anos, ele tem os cabelos um pouco grisalhos e uma calva que começa a se pronunciar. Os seus olhos parecem estar sempre marejados. Aos sussurros, ele definiu a depressão que há três anos o corrói: “É uma dor sem fim, uma angústia e uma tristeza que não passam nunca, um mergulho permanente no horror." Esse estado de espírito é acompanhado por fortes dores na nuca, inapetência e um cansaço infindável, exacerbado por noites agitadas e insones. Desde que afundou na depressão, Tezoto tomou um sem-número de medicamentos. Nenhum deles fez efeito. "Ele simplesmente não melhora", disse Inês. "Vê-lo assim é morrer um pouco a cada dia."

Eram oito e meia da manhã de uma quarta-feira. O ex-metalúrgico fora um dos primeiros pacientes a chegar ao ambulatório psiquiátrico do Hospital das Clínicas de São Paulo, onde seria submetido a mais uma sessão de eletroconvulsoterapia, ou ECT, o novo nome para um dos mais atacados tratamentos psiquiátricos, $\mathrm{O}$ eletrochoque. Tezoto passara por 35 aplicações, o triplo das sessões consideradas suficientes para ultrapassar uma crise depressiva. Os efeitos não se fizeram sentir, embora 
ele admita que, nos dias em que toma choque, se sinta um pouco mais aliviado. Uma enfermeira sorridente logo o chamou. "Eu durmo e não sinto nada", explicou Tezoto, sem ansiedade, antes de desaparecer por uma porta entreaberta.

\section{$[\ldots]$}

Criado há setenta anos, e praticamente banido da psiquiatria por quase quatro décadas, o eletrochoque voltou com força. Instituições de prestígio, como o hospital da Universidade Harvard, atendem pacientes voluntários para a eletroconvulsoterapia. Nos Estados Unidos, mais de 100 mil pacientes se submetem ao tratamento a cada ano. O Hospital das Clínicas é um dos poucos que nunca deixaram de usá-lo, desde que ele foi introduzido ali, nos anos 40. No final da década de 90, porém, o número de pacientes não chegava a dez por semana - hoje são oitenta. "Essa é agora a ala mais movimentada do hospital psiquiátrico", contou Sérgio Rigonatti, psiquiatra-chefe do ambulatório de ECT. "O preconceito que estigmatizou o eletrochoque vai aos poucos desaparecendo.

Os cientistas não têm uma explicação conclusiva sobre o mecanismo do eletrochoque. Ainda não se sabe, por exemplo, por que a terapia é mais eficiente nas depressões graves e nos transtornos bipolares. As diversas células do cérebro comunicam-se através de pulsos energéticos, a neurotransmissão. Vários neurotransmissores - substâncias químicas que intervêm no processo - já foram identificados. Um é a dopamina, associada à sensação de prazer. Outro é a serotonina, envolvida no controle do sono, do apetite e do humor. Um terceiro é a adrenalina, que é ativada nas situações de perigo, preparando o organismo para o combate ou a fuga. Em casos de transtornos mentais, esses neurotransmissores entram em pane. $\mathrm{Na}$ depressão, imagina-se que as informações de bem-estar cheguem 
truncadas. O resultado é a apatia, a tristeza, a angústia, a insônia. "É como a brincadeira do telefone sem fio", comparou Julieta Guevara, durante uma conversa em seu consultório na Barra da Tijuca. "A informação passada através de um cochicho nunca chega correta até o último da fila." Da mesma forma, quando algo na neurotransmissão começa a sair errado, parte da informação se perde, e, como os neurônios no final da linha não sabem o que se espera deles, dá-se a confusão, da qual resultariam os transtornos mentais.

Julieta Guevara acredita na hipótese de que os estímulos provocados pelo eletrochoque limpem as conexões entre os neurônios, de modo que a neurotransmissão passe a se realizar de forma clara, resultando na volta do equilíbrio da mente. $\mathrm{O}$ psiquiatra Sérgio Rigonatti utiliza uma velha imagem para tentar ilustrar o efeito da terapia: "É como o tapa que dávamos nos antigos televisores, para que a imagem defeituosa voltasse ao normal." O "tapa" elétrico no cérebro provocaria uma desconexão momentânea dos neurônios, que seriam religados de maneira diferente.

O psiquiatra paulista Jonas Melman, da Secretaria Municipal de Saúde, acha que, apesar dos exageros, os medicamentos são a forma mais adequada de tratar os transtornos da mente. Ele acha lamentável que uma técnica invasiva como o eletrochoque tenha voltado com força ao receituário psiquiátrico. "Como os medicamentos estão cada vez mais eficientes, a necessidade de se recorrer ao eletrochoque deveria ser cada vez menor", ele afirma. "Em vez disso, cada vez mais pacientes são submetidos a essa terapia.

Para Marco Antonio Brasil, a psiquiatria tem deixado em segundo plano a origem psicossocial dos transtornos psicológicos. Muitos deles, como a bulimia, a anorexia, o estresse e a síndrome do pânico, ele diz, são provocados por pressões da vida contemporânea. O psiquiatra Renato Del Sant, do Hospital das Clínicas de São Paulo, 
defensor dos eletrochoques, vai na mesma linha: "Os remédios estão substituindo totalmente as conversas com os pacientes. Corremos o risco de tratar a doença mental meramente como distúrbio físico, e não como um comportamento humano.

Se o paciente está triste, toma Prozac; se está impotente, toma Viagra. A visão biológica é tão preponderante que as escolas de medicina, segundo ele, estão reduzindo a carga horária dos estudos de psicopatologia e aumentando a dos métodos neurocientíficos. "Dessa forma, a psiquiatria tende a desaparecer", radicaliza Del Sant. "Nos tornaremos neurocientistas, ou neurologistas, deixando a psicopatologia para os psicanalistas.

Menos de um mês depois do tratamento com eletrochoque, Trancuilo Tezoto tentou se suicidar. Subiu na laje de sua casa e se jogou de uma altura de quase 5 metros. Dias antes, sua mulher insistira com os médicos da psiquiatria do Hospital das Clínicas para que o internassem. "Os médicos me disseram para tomar conta dele até que surgisse uma vaga no hospital", ela contou. "Mas ele estava muito triste, esperou um descuido meu e se jogou. Nem os remédios, nem o eletrochoque foram capazes de pôr fim a sua angústia. ${ }^{19}$

\section{$[\cdots]$}

Se no campo da saúde mental a aplicação do eletrochoque é fator de preocupação, o é em igual em medida o desenvolvimento vertiginoso da psicofarmacologia, com toda a sorte de medicamentos prontos para agir invasiva e indiscriminadamente sobre os mais variados aspectos da vida subjetiva. No entanto, sejam as técnicas controversas como a eletroconvulsoterapia ou mais bem aceitas como os psicotrópicos, mais importante e preocupante do que estas em si é a concepção de homem que as possibilita, isto é, é o avanço da autoridade e da legitimidade da vulgar

19 DIEGUEZ, Consuelo. Eletrochoque. Revista Piauí. Edição 21, Junho de 2008. Disponível em:<http://piaui.folha.uol.com.br/materia/eletrochoque/> Acesso em: 07 de julho de 2017. 
ideia de que a subjetividade (com suas mais variadas dimensões) pode ser reduzida ao cérebro, estejamos falando de alguma forma de sofrimento ou de qualquer aspecto humano tido como saudável, tais como o modo de decidir e resolver problemas do diaa-dia, preferências políticas, inclinações profissionais, propensões religiosas, capacidade intelectual, dotes artísticos etc.

Destaco excertos da reportagem de Consuelo Dieguez para a revista Piauí, portanto, não para problematizar a utilização da técnica do eletrochoque, mas como uma espécie de prólogo do que será dito daqui em diante, isto é, para ilustrar algo ainda mais elementar e que se trata do objeto desta dissertação: a concepção de homem das neurociências, que tem ganhado cada vez mais destaque nos meios de comunicação de massa e tem sido cada vez mais aceita pelas pessoas, a despeito de qualquer estranhamento que suas flagrantes coisificação e vagueza poderiam (ou deveriam) causar.

Ex-professor da Universidade de São Paulo, hoje na École Normale Supérieure, o filósofo francês Francis Wolff inicia capítulo dedicado à apresentação da figura de homem das neurociências, de seu livro Nossa humanidade: De Aristóteles às neurociências, com uma famosa passagem de Michel Foucault, em As palavras e as coisas, de 1966:

\begin{abstract}
Uma coisa é certa: o homem não é o mais velho problema, nem o mais constante, que se tenha colocado para o saber humano. [...] Entre todas as mutações que atingiram o saber das coisas e de sua ordem [...], uma só, a que começou há um século e meio e talvez esteja em vias de se encerrar, deixou aparecer a figura do homem [...]. O homem é uma invenção cuja data recente a arqueologia do nosso pensamento mostra com facilidade. E talvez seu fim próximo. $^{20}$
\end{abstract}

Para Wolff, Foucault tinha razão. A morte do homem que ele previu é aquilo a que temos assistido desde a virada do século XX para o XXI. Não obstante, Foucault se equivocou quanto à causa hipotética do fim do homem como objeto do saber. Sua predição estava calcada na onipotência cada vez maior do objeto "linguagem" nas ciências do homem. No entanto, o paradigma que hoje tem se imposto sobre as Ciências Humanas não é o da Linguística, mas sim o da explicação naturalista:

\footnotetext{
${ }^{20}$ FOUCAULT, Michel. Les mots et les choses. Paris: Gallimard, 1966, p. 398. Apud WOLFF, Francis.
} Nossa humanidade: de Aristóteles às neurociências. São Paulo: UNESP, 2012, p. 107. 
[...] o paradigma que hoje essa nova figura de homem que vem tornando obsoleto o homem estrutural e, com ele, a onipotência do simbólico, do inconsciente representativo, da oposição da cultura à natureza ou da humanidade à animalidade, essa figura não nasce [...] de uma Ciência do Homem (a Linguística) que acabaria por fagocitar as outras, mas de fora, de um grupo inédito de Ciências que tende a absorvê-las; ela se deve ao prodigioso desenvolvimento das Ciências do vivente e de suas diversas dependências: [entre elas, as] Neurociências (apoiadas na formação de imagens do cérebro e nas novas técnicas de Biologia Molecular, que permitem ver o cérebro em ação) $[\ldots . .]^{21}$.

No início da década de 1980, o jornalista estadunidense Tom Wolfe relatou:

Em 1979, a psicologia freudiana era tratada apenas como uma nota histórica interessante. A nova fronteira da moda era o estudo clínico do sistema nervoso central. [...] Hoje os novos sábios sondam aqui, sondam acolá, fatiam daqui, fatiam de lá, projetam seus slides e consideram os constructos mentais de Freud, suas libidos, "complexo de Édipo" e o resto peculiares charlatanices de antigamente, na mesma linha do "magnetismo animal" de Mesmer $^{22}$.

Três décadas depois, desabafou Sérgio Augusto, colunista do jornal $O$ Estado de São Paulo: “Em 2012, a palavra do ano foi menos que um vocábulo, foi um prefixo: neuro. [...] 2012 foi o ano do neuroisso, do neuroaquilo, do neurotudo e, em última instância, do neuronada"23.

O que mais interessa em seu desabafo, no entanto, não é o tom de deboche, mas o fenômeno contra o qual reage: a recente ascensão da neurociência e de suas incontáveis considerações sobre o homem nas esferas do conhecimento e da cultura. Como afirma o neurocientista Sidarta Ribeiro, vivemos um "tempo de cérebro"24. Ou então, tomando emprestada a visão do antropólogo Rogério Azize, encontramo-nos em meio a uma "nova ordem cerebral" 25 .

\footnotetext{
${ }^{21}$ WOLFF, Francis. Nossa humanidade: de Aristóteles às neurociências. São Paulo: UNESP, 2012, p. 108

${ }^{22}$ WOLFE, Tom. In our time. New York: Farrar, Straus and Giroux, 1980 apud HORGAN, John. A mente desconhecida: Por que a ciência não consegue replicar, medicar e explicar o cérebro humano. São Paulo: Companhia das Letras, 2002, p. 25.

23 AUGUSTO, Sérgio. O ano da neurocascata. O Estado de São Paulo, 2012. Disponível em: <http://alias.estadao.com.br/noticias/geral,o-ano-da-neurocascata-imp-,978978>. Acesso em: 15 de maio 2017.

${ }^{24}$ RIBEIRO, Sidarta. Tempo de cérebro. Em: Revista Estudos Avançados, v.27, n. 77, 2013, p.7.

${ }^{25}$ Cf. AZIZE, Rogério A nova ordem cerebral: a concepção de 'pessoa' na difusão neurocientífica. Tese de doutorado em Antropologia Social, Museu Nacional, 2010.
} 
Atendendo ao clamor de toda a comunidade neurocientífica dos Estados Unidos na busca por mais fomentos, os anos 1990-1999 foram proclamados por George W. Bush como a "década do cérebro", obedecendo a uma lei aprovada pelo Congresso, que reconheceu a capacidade da neurociência contemporânea de revolucionar a humanidade e a sociedade, depositando muitas esperanças nessa nova área do conhecimento.

No início da década de 1990, Erik R. Kandel ${ }^{26}$ afirmou crer que grande parte dos biólogos estava convencida de que o "espírito" seria para a biologia do século XXI o que o gene foi para a biologia do século $\mathrm{XX}^{27}$. De lá para cá, debruçando-se sobre o cérebro para explicar como essa "máquina biológica" produz essa "coisa" apenas aparentemente metafísica denominada espírito (a consciência, as ideias, os valores, as emoções, o sofrimento, o bem-estar...), a neurociência vem sendo colocada em prática ao redor do globo em "diversos Human Brain Projects, ${ }^{[28]}$ ao estilo do Projeto Genoma"29.

$\mathrm{Na}$ esteira dos mais recentes desenvolvimentos científico-tecnológicos, sobretudo das novas modalidades de visualização ${ }^{30}$ e de alteração ${ }^{31}$ do funcionamento cerebral, tem-se assistido à incessante difusão e à crescente aceitação do conhecimento neurocientífico, cuja concepção de homem e cujo modo de tratá-lo cientificamente têm penetrado de maneira profunda o campo das disciplinas $\mathrm{psi}^{32}$, o âmbito das práticas de governo $^{33}$ e a esfera da cultura ${ }^{34}$, repercutindo nos mais variados domínios da vida -

${ }^{26}$ Neurocientista estadunidense, ganhador do Prêmio Nobel de Fisiologia e Medicina de 2000 por seus estudos sobre os mecanismos neurais de formação das memórias.

${ }^{27}$ Cf. EHRENBERG, Alain. O sujeito cerebral. Psicologia Clínica, Rio de Janeiro, vol.21, 2009, p. 187.

${ }^{28}$ GIANINI, Tatiana. A mente ao vivo e em cores. Revista Veja. Edição 2311, p. 80-86, 6 de março de 2013.

${ }^{29}$ Cf. EHRENBERG, Alain. O sujeito cerebral. Psicologia Clínica, Rio de Janeiro, vol.21, 2009, p. 187.

${ }^{30}$ Refiro-me aos CAT scan (computer assisted tomography), MRI (magnetic resonance imaging), PET (positron emission tomography) e fMRI (functional magnetic resonance imaging).Cf. LECOINTRE, Marisa Russo. Emoção e cognição: uma abordagem científica das emoções. Filosofia e História da Biologia, v.2, n. 1, 2007, p. 343.

31 Refiro-me à Psicofarmacologia, Estimulação Magnética Transcraniana (EMT), Estimulação Transcraniana de Corrente Contínua (ETCC) e Eletroconvulsoterapia (ECT), popularmente conhecida como "eletrochoque".

32 Cf. LECOINTRE, Marisa Russo. Emoção e cognição: uma abordagem científica das emoções. Filosofia e História da Biologia, v.2, n. 1, 2007. LIMA, Rossano Cabral A cerebralização do autismo: notas preliminares. Em: COUTO, Maria Cristina Ventura e MARTINEZ, Renata Gomes (orgs.). Saúde Mental e Saúde Pública: questões para a agenda da reforma psiquiátrica. NUPPSAM/IPUB/UFRJ, Rio de Janeiro. 2007. ROUDINESCO, Elizabeth. Por quê a psicanálise? Rio de Janeiro: Zahar, 2000. WOLFF, Francis. Nossa humanidade: de Aristóteles às neurociências. São Paulo: Unesp, 2012.

${ }^{33}$ Cf. LIMA, Rossano Cabral A cerebralização do autismo: notas preliminares. Em: COUTO, Maria Cristina Ventura; MARTINEZ, Renata Gomes (orgs.). Saúde Mental e Saúde Pública: questões para a agenda da reforma psiquiátrica. NUPPSAM/IPUB/UFRJ, Rio de Janeiro. 2007. ROSE, Nikolas \& 
como o da saúde mental, em que explicações neuroquímicas e técnicas farmacológicas, além de eletro-físicas de tratamento, se multiplicam e se atualizam dia após dia e, sendo aceitas pelos indivíduos, precipitam novos modos de representação do sofrimento e da própria subjetividade.

De acordo com o sociólogo Alain Ehrenberg, podem-se distinguir dois programas de neurociências: o "fraco" e o "forte". O "fraco" se detém no estudo de doenças neurológicas como Alzheimer e Parkinson e na investigação dos possíveis aspectos neurológicos das doenças da mente. O "forte", por sua vez, identifica conhecimento do cérebro ao conhecimento do sujeito, visando à construção de uma redutora biologia do espírito e do indivíduo que, traduzida em termos práticos, possibilitaria a intervenção neurológica sobre as doenças mentais (uma vez que a mente não passa de um produto da atividade bioquímica do cérebro) e sobre nossas capacidades individuais de agir e decidir na vida cotidiana ${ }^{35}$.

Do programa "fraco" para o "forte" há um salto qualitativo considerável. Isso porque a partir da década de 1980, impulsionada pelas novas tecnologias de visualização cerebral que permitem observar a esse órgão em ação e não mais morto e fatiado, além do impulso advindo dos avanços na biologia molecular, as neurociências, tradicionalmente interessadas "pelo movimento, pelos sentidos (visão, audição etc.), pela aprendizagem e pelas doenças propriamente neurológicas (Alzheimer, Parkinson)”, passaram a pensar-se como ciência do homem total, reduzindo o social e o mental ao neurológico e estendendo sua abordagem "às emoções, aos comportamentos sociais e aos sentimentos morais" 36 .

ABI-RACHED, Joelle. Neuro: the new brain sciences and the management of the mind. Princeton: Princeton University Press, 2013.

${ }^{34}$ Cf. AZIZE, Rogério A nova ordem cerebral: a concepção de 'pessoa' na difusão neurocientifica. Tese de doutorado em Antropologia Social, Museu Nacional, 2010. EHRENBERG, Alain. $O$ sujeito cerebral. Psicologia Clínica, Rio de Janeiro, vol.21, p.187-213, 2009. ORTEGA, Francisco. Neurosciences, neuroculture and cerebral self-help. Interface - Comunic., Saude, Educ., v.13, n.31, 2009, p.247-60.ORTEGA, Francisco e BEZERRA JR., Benilton. O sujeito cerebral, Viver Mente e Cérebro, v.162, 2006, p.16-17.ORTEGA, Francisco e VIDAL, Fernando. O sujeito cerebral, Scientific American Brasil, v.52, 2006, p.20-20. PERCHERON, Gérard. Neuromitologias: cérebro, indivíduo, espécie e sociedade. Em: VEYNE, Paul et al. Indivíduo e Poder. Lisboa: Edições 70, 1987. WOLFF, Francis. Nossa humanidade: de Aristóteles às neurociências. São Paulo: Unesp, 2012

${ }^{35}$ EHRENBERG, Alain. O sujeito cerebral. Psicologia Clínica, Rio de Janeiro, vol.21, 2009, p. 189.

${ }^{36}$ Ibidem, p. 187-188. 
Tal como também observou Francis Wolff:

Já não se trata mais de 'explicar o social pelo social', para retomar a célebre frase de Durkheim, mas o social pelo cognitivo e este, por sua vez (quando possível) pelo neurológico e, por conseguinte, pelo biológico. ${ }^{37}$

De acordo com o filósofo, para o paradigma naturalista da neurociência, o cérebro é o "ponto focal do conhecimento" acerca do “objeto - homem", sendo "o centro único de onde, se supõe, emana obrigatoriamente tudo o que é humano" Contém, assim, a humanidade, pois é o "órgão" da subjetividade, como o estômago é o da digestão, o coração o da circulação etc.

Logo, o que você é se identifica de modo matemático com o que é o seu cérebro, de tal maneira que se pode falar em um novo cogito - "existo porque tenho um cérebro que pensa"39.

É nesse sentido que Jean-Pierre Changeux, quando questionado se acredita que a "neurociência está fadada a novos desenvolvimentos fundamentais", responde: "Sim, é o futuro. É a ciência do futuro, do porvir [...]. Acredito que a grande incógnita agora é o cérebro do homem... Compreender o que nós somos. O quê é o homem "40.

Francis Crick, ganhador do Nobel pela descoberta da dupla hélice do DNA, expôs de maneira clara e concisa a hipótese fundamental que sustenta e impulsiona o saber neurocientífico em sua totalidade e que, atualmente, é recepcionada como algo evidente, sem qualquer impropriedade. Disse ele:

Você, suas alegrias e tristezas, suas memórias e ambições, seu senso de identidade pessoal e livre-arbítrio, na verdade nada mais são do que o comportamento de um vasto conjunto de células nervosas e as moléculas a elas associadas [...] Você não passa de um baralho de neurônios. ${ }^{41}$

\footnotetext{
${ }^{37}$ WOLFF, Francis. Nossa humanidade: de Aristóteles às neurociências. São Paulo: Unesp, 2012, p. 194.

${ }^{38}$ Ibidem, p. 194.

39 AZIZE, Rogério A nova ordem cerebral: a concepção de 'pessoa' na difusão neurocientífica. Tese de doutorado em Antropologia Social, Museu Nacional, 2010, p. 2.

${ }^{40}$ MOURA, Mariluce. A biologia sob a consciência. Revista Pesquisa FAPESP. São Paulo, n. 186, p. 1017, agosto de 2011.

${ }^{41}$ CRICK, Francis. Astonishing hypothesis: The scientific search for the soul. New York: Simon and Schuster, 1995, p.3, tradução livre.
} 
Não é tarefa difícil encontrar a difusão dessa perspectiva acerca do homem em programas televisivos e radiofônicos ${ }^{42}$, revistas de ampla circulação ${ }^{43}$ e de circulação restrita ${ }^{44}$, jornais ${ }^{45}$, em domínios da internet, aplicativos (apps) de treinamento cerebral para tablets e smartphones, sem contar as estantes das grandes livrarias com obras sobre neuroascese, auto-ajuda cerebral e best-sellers de divulgação neurocientífica por meio dos quais neurobiólogos renomados buscam difundir em linguagem acessível suas descobertas e hipóteses a respeito de inúmeros aspectos de nossas vidas ${ }^{46}$.

Uma boa ilustração da difusão da concepção neurocientífica encontra-se em $O$ cérebro nosso de cada dia: descoberta da neurociência sobre a vida cotidiana ${ }^{47}$, da neurocientista brasileira Suzana Herculano-Houzel, ex-professora da UFRJ, atualmente na Universidade Vanderbilt, nos Estados Unidos. Diz ela:

\begin{abstract}
A vida cotidiana é o reflexo da atividade do cérebro a cada instante, a cada dia. Os ensaios incluídos neste livro apresentam, em linguagem simples, descobertas recentes da pesquisa sobre o cérebro relacionadas ao cotidiano de todos nós. A proposta não é explicar como o cérebro e a mente funcionam, mas sim expor alguns princípios através dos exemplos do cotidiano, na esperança de despertar no leitor a curiosidade e a vontade de entender como o cérebro faz de nós o que somos e fazemos no dia-a-dia. ${ }^{48}$
\end{abstract}

Outro exemplo interessante da abordagem neuronal encontra-se na última obra de divulgação de Jean-Pierre Changeux. Partindo de elucubrações a respeito da bioquímica cerebral para forjar uma teoria completamente determinista e reducionista

${ }^{42}$ O programa Encontro com Fátima Bernardes, por exemplo, conta com a presença regular de um neurocientista; o Fantástico apresentou a série Neuro Lógica espaço dedicado à "neurociência do cotidiano" da ex-professora da Universidade Federal do Rio de Janeiro, Suzana Herculano-Houzel. O mesmo tema era a base do programa Isso é coisa da sua cabeça, da rádio Band News FM - SP, apresentado pela jornalista Inês de Castro. Afora outras dezenas de aparições recorrentes desta temática.

${ }^{43}$ Revistas Veja, Época, SuperInteressante, Galileu e Piauí.

${ }^{44}$ Revistas Pesquisa FAPESP, Espaço Aberto - USP, Mente \& Cérebro e Scientific American.

45 Suzana Herculano-Houzel (UFRJ) é colunista da Folha de S. Paulo e da Mente \& Cérebro. Sidarta Ribeiro (UFRN) também é colunista da Mente \& Cérebro.

${ }^{46}$ A difusão da linguagem e da visão neurocientífica da subjetividade pode ser conferida nitidamente em diversas obras de divulgação (em muitas já pelos títulos): cf. CHANGEUX, Jean-Pierre. O homem neuronal. Lisboa: Publicações Dom Quixote, 1991. DAMASIO, Antonio. E o cérebro criou o homem. São Paulo: Companhia das Letras, 2011. DAMASIO, Antonio. O erro de Descartes. São Paulo: Companhia das Letras, 2012; GAZZANIGA, Michael. The social brain: Discovering the networks of the mind. New York: Basic Books, 1985. GAZZANIGA, Michael. The ethical brain: the science of our moral dilemmas. Harper Perennial, 2005; HERCULANO-HOUZEL, Suzana. Pílulas de neurociência para uma vida melhor. Rio de Janeiro: Sextante, 2009 etc.

${ }^{47}$ HERCULANO-HOUZEL, Suzana. O cérebro nosso de cada dia: descoberta da neurociência sobre a vida cotidiana. Rio de Janeiro: Vieira \& Lent, 2012.

48 Ibidem, p. 17. 
da subjetividade (já presente em seu o Homem neuronal, originalmente de 1983), Changeux salta daí para uma análise da história e da cultura que lhe permite acreditar na possibilidade de "dialogar" em termos cerebralistas com pensadores como Émile Durkheim, Karl Marx, Michel Foucault e Pierre Bourdieu. Com este último, aliás, pensando na possibilidade de encontrar o correlato neural do habitus ${ }^{49}$. Em uma formulação que deve causar estranhamento a todo sociólogo, o autor afirma:

\begin{abstract}
O cérebro do homem, desde a mais tenra idade, é um superprodutor de significados. O cérebro dos homens reunidos em sociedade produziu 'representações coletivas' [que] trazem uma paz interior, um reconforto pela estimulação em nosso imaginário de sistemas de recompensa que ativam neuromediadores moduladores (dopaminas, opiáceos). Ousaria dizer que o ópio do povo ganha uma plausibilidade neural. ${ }^{50}$
\end{abstract}

$\mathrm{Na}$ esteira da crença a respeito do cérebro como determinante central de tudo o que somos e podemos vir a ser, atualmente somos bombardeados com artigos e reportagens sobre projetos neurocientíficos versando sobre descobertas de penicilinas das doenças mentais (como a cetamina, um anti-inflamatório usado na Segunda Guerra Mundial e já em fase de teste em humanos ${ }^{51}$ ), enzimas capazes de alterar nossas memórias, contribuindo para memorização de informações ou para o seu esquecimento $^{52}$, “o papel julgador" do córtex pré-frontal ${ }^{53}$ (o "substituto" cerebral do superego psicanalítico), descobertas dos determinantes cerebrais de um sem número de fenômenos, enfim, uma série de conhecimentos que - se aposta - proverão a melhora da qualidade de vida e uma existência plena e feliz a todos.

Assim foi que no $9^{\circ}$ Congresso Internacional sobre Cérebro, Comportamento $e$ Emoções (realizado em setembro de 2013 na cidade de São Paulo, com a participação de neurocientistas reconhecidos do Brasil e do exterior) discutiu-se temas tais como "as bases biológicas do comportamento criminoso", "a anatomia da violência", "a biologia do suicídio", "a biologia das tomadas de decisões", "disfunção executiva e as más

\footnotetext{
${ }^{49}$ CHANGEUX, Jean-Pierre. A verdade, o belo e o bem: uma nova abordagem neuronal. Rio de Janeiro: Civilização Brasileira, 2013, p. 22.

${ }^{50}$ Ibidem, p 423.

${ }^{51}$ CUMINALE, Natalia. Novas esperanças contra a depressão. Revista Veja. Edição 2297, p.152-159, 28 de novembro de 2012.

52 Cf. Descoberta a proteína que pode apagar memória. Disponível em: <http://noticias.terra.com.br/ciencia/interna/0,,OI1842276-EI8147,00.html> Acessado em: 13 de março de 2017.

${ }^{53}$ HERCULANO-HOUZEL, Suzana. Segredos. Mente e Cérebro. No 267. Abril de 2015.
} 
escolhas na vida", "a neurobiologia da inveja, da culpa, da ternura e da criatividade", a "extinção do medo", “como apagar memórias traumáticas", "tratamentos neurocirúrgicos dos transtornos psiquiátricos", "prevenção precoce de comportamentos violentos (lições da genética e epigenética)", "psicofarmacologia na infância" etc. ${ }^{54}$

Nesse contexto é defendido o retorno da prática da eletroconvulsoterapia (ECT), o mais controverso dos tratamentos psiquiátricos que, depois de anos de banimento, foi regulamentado pelo Conselho Federal de Medicina no ano de $2002{ }^{55}$, assim como as técnicas profundamente invasivas de Estimulação Magnética Transcraniana ${ }^{56}$ e de Estimulação Transcraniana por Corrente Contínua $(\text { ETCC })^{57}$, consideradas uma revolução no tratamento da depressão e muitos outros "distúrbios neurológicos" 58.

Nessa direção, tem-se visto tanto nos discursos e práticas "rigorosamente" científicos, quanto nos diferentes meios em que o conhecimento neurocientífico tem sido reproduzido, que "o cérebro responde cada vez mais por tudo aquilo que outrora nos acostumamos a atribuir à pessoa, ao indivíduo, ao sujeito" ${ }^{, 59}$, fenômeno que aqui pode ser designado pelo conceito de cerebralização, empregado em sentido diverso daquele tal qual é compreendido no ramo das ciências biológicas. Neste campo, que o concebeu, o conceito de cerebralização (sinônimo de cefalização) diz respeito ao desenvolvimento paulatino do cérebro no processo evolutivo das espécies e é utilizado a par e passo com o conceito de hominização. Em minha perspectiva, sirvo-me desta expressão para aludir a essa recente e eficaz redução teórica do sujeito à sua massa cerebral, de suas ações, inventividade e debilidade ao déficit ou ao excesso de secreções químicas e aos consequentes efeitos em termos de impulsos elétricos, processo teóricocognitivo que tem caracterizado os esforços neurocientíficos na produção de

\footnotetext{
${ }^{54}$ Dados referentes à edição de 2013 do evento, disponíveis em arquivo pessoal.

${ }^{55}$ À revelia do passado, o eletrochoque é hoje legitimado devido ao "simples" uso de uma anestesia geral, exigência da Resolução do Conselho Federal de Medicina (Cf. Resolução CFM n ${ }^{\circ}$ 1.640/2002. Dispõe sobre a eletroconvulsoterapia e dá outras providências. Brasília/DF: [s.n.], 10 jul. 2002. Disponível em: <http://www.portalmedico.org.br/resolucoes/cfm/ 2002/1640_2002.htm>. Acesso em $04 \mathrm{mar}$. 2015).Cf. DIEGUEZ, Consuelo. Eletrochoque. Piauí, n. 21, 2008. Disponível em: <http://piaui.folha.uol.com.br/materia/eletrochoque/ >. Acesso em: 12 mar. 2016.

${ }^{56}$ Cf. IZQUIERDO, Ivan; KAPCZINSKI, Flávio; QUEVEDO, João. Bases biológicas dos transtornos psiquiátricos. Porto Alegre: Artmed, 2011.

57 FIORAVANTI, Carlos. Energia para os neurônios: estimulação elétrica de baixa intensidade amadurece como técnica promissora no tratamento contra a depressão. Revista Pesquisa FAPESP. São Paulo, n. 216, p. 16-21, fevereiro de 2014.

${ }^{58}$ Todas elas são oferecidas bem perto de nós: no Hospital das Clínicas e no Hospital Universitário da Universidade de São Paulo.

${ }^{59}$ ORTEGA, Francisco e BEZERRA JR., Benilton. O sujeito cerebral, Viver Mente e Cérebro, v.162, 2006, p. 16.
} 
conhecimentos sobre diversos aspectos da subjetividade, processo este, por sua vez, estreitamente dependente do movimento da sociedade como um todo.

Questionar tal conhecimento, a crença a respeito do homem que lhe serve de base é algo urgente então, pois “da resposta à pergunta 'O que é o homem?' depende tudo o que podemos conhecer, tudo o que devemos fazer e tudo o que podemos esperar" ${ }^{\prime 60}$, é o que diz Wolff, inspirando em Kant. Assim, uma discussão a respeito da vasta legitimidade e autoridade de que têm gozado a concepção neurocientífica de homem e o respectivo processo de cerebralização da subjetividade ilumina ou municia o debate a respeito de um número razoável de temas correlatos para os quais tal visão serve como pressuposto fundamental ou, o que é pior, como verdade irrefutável: a importância crescente dos diagnósticos e dos manuais diagnósticos; a medicalização da vida, sobretudo da infância; a redefinição tanto da etiologia quanto das práticas terapêuticas relativas a inúmeras patologias da mente, tais como a depressão e o autismo; a tecnologia médica; o crescimento da indústria farmacêutica; as técnicas refinadas do marketing farmacêutico etc.

Para tanto, inicialmente, o conhecimento neurocientífico deve ser pensado nos termos de algo que lhe é essencial: certa aposta no sentido de que há uma relação de determinação estreita e direta entre o cérebro (que seria a essência da subjetividade) e o sujeito, crença esta que, como já adiantado, ao contrário do que se é levado a pensar, não foi forjada pela neurociência contemporânea, sendo antes o seu pressuposto, já que suas origens remontam, no mínimo, ao século XVIII.

Porém, embora a concepção cerebral de sujeito não seja genuinamente nova, ela tomou feições mais densas e precisas, bem como uma nova eficácia política, social e cognitiva a partir do momento em que a neurociência se tornou sua fiel depositária, na década de 1970. Pois então, apenas a partir dessa década (quando a neurociência se afastou das demais disciplinas do campo das ciências cognitivas, que relegaram o cérebro a um segundo plano) é que a figura do sujeito cerebral alçou voos maiores para, no fim do século XX e início do XXI, tornar-se concepção dominante de homem.

Assim sendo, não obstante a importância atribuída no passado ao cérebro nas discussões acerca do sujeito, somente considerando os desdobramentos das últimas décadas é que se pode falar em um processo efetivo e abrangente de cerebralização da

\footnotetext{
${ }^{60}$ WOLFF, Francis. Nossa humanidade: de Aristóteles às neurociências. São Paulo: Unesp, 2012, p. 8.
} 
subjetividade. O fato, portanto, é que apenas recentemente "esta figura de homem se tornou culturalmente preponderante" ${ }^{, 61}$, passando a gozar de uma dose cavalar de autoridade e aparecendo como fundamento legítimo de uma série de discursos e práticas naturalistas que cerebralizam a consciência, o pensamento, a memória, a ética, a felicidade, a genialidade, a culpa, o sofrimento etc.; discursos e práticas que, para além de serem produzidos em centros de pesquisa renomados (e largamente financiados) e difundidos pela indústria midiática, são aceitos e mobilizados semanticamente pelos sujeitos na condução de suas vidas.

Isso suscita um questionamento central do qual se deve partir para a problematização sociológica do atual fenômeno da cerebralização: se a figura antropológica do "sujeito cerebral" data de alguns séculos atrás, como dar conta do fato de somente há poucas décadas haver ela logrado tamanha aceitação, seja no âmbito científico, seja no âmbito da cultura? Posta em outros termos: em quê se sustentam e do quê dependem hoje, em última instância, a estabilidade e a preponderância desta concepção de homem nos âmbitos do conhecimento e da cultura em detrimento, por exemplo, da concepção psicanalítica, que já não ocupa o mesmo espaço cultural, midiático, político etc. de outrora?

\section{Olhares sociológicos existentes e algumas críticas}

Tanto a sociologia quanto as disciplinas vizinhas têm esbarrado no tema, mas pouco tem sido dito sobre as questões lançadas acima. Na sociologia há dois esforços teóricos - o de Nicholas Rose e Joelle Abi Rached ${ }^{62}$ e o de Alain Ehrenberg ${ }^{63}$ - sendo o segundo o mais significativo aos meus olhos, uma vez que, ao se debruçar sobre a representação de um objeto como problema de pesquisa, tal pesquisa deva investigar de alguma maneira o próprio objeto representado (no caso, o próprio homem), esforço encontrado em alguma medida em Ehrenberg, mas não em Rose e Abi-Rached. Ainda que se trate de um trabalho antropológico filiado à tradição dos estudos da noção de

\footnotetext{
${ }^{61}$ WOLFF, Francis. Nossa humanidade: de Aristóteles às neurociências. São Paulo: Unesp, 2012, p. 108.

${ }^{62} \mathrm{Cf}$. ROSE, Nikolas\& ABI-RACHED, Joelle. Neuro: the new brain sciences and the management of the mind. Princeton: Princeton University Press, 2013

${ }^{63}$ Cf. EHRENBERG, Alain. O sujeito cerebral. Psicologia Clínica, Rio de Janeiro, vol.21, 2009.
} 
pessoa, a tese de doutorado de Rogério Azize também arrisca um entendimento sociológico pertinente.

Inspirados nos conceitos foucaultianos de governamentalidade e biopolítica ${ }^{64}$, Rose e Abi-Rached vislumbram a neurociência como um corpo teórico que confere inteligibilidade a problemas sociais e políticos recém-surgidos, possibilitando o desenvolvimento de modalidades de governo correspondentes e que fornecem uma nova linguagem para que os sujeitos compreendam a si próprios e desenvolvam novas competências no que toca ao gerenciamento de seus selves. A emergência desse corpo teórico é relacionada por eles a mudanças "conceituais, tecnológicas, econômicas e biopolíticas" ${ }^{\prime 65}$, resumindo, assim, as mudanças de cunho econômico àquelas que dizem respeito aos custos que inúmeras doenças comprovadamente relacionadas ao cérebro, e passíveis de sê-lo, acarretam ao orçamento público, não havendo qualquer extensão do termo "econômico" ao processo de reprodução da sociedade nem a qualquer questionamento sobre uma mudança do próprio homem neste processo, o qual é tratado como homem genérico e não como um homem datado, transformado na interação entre natureza e história, cuja condição social e histórica afetaria, de alguma maneira, as representações (a imagem, a figura, a ideologia) a seu respeito, tanto no plano científico quanto no plano das representações correntes, além do modo como ele próprio se relaciona com tais representações.

O antropólogo Rogério Lopes Azize, em sua tese de doutorado pelo Museu Nacional $^{66}$, especificamente em subitem (do capítulo III) - O cérebro como sujeito do capitalismo tardio -, observa uma afinidade eletiva entre o discurso da neurociência e o discurso referente à organização empresarial, por um lado, e as habilidades esperadas do indivíduo segundo a lógica da organização do trabalho no regime capitalista de acumulação, por outro lado, de modo que os conceitos da neurociência, como "plasticidade neuronal", "sistema de recompensa", "motivação" (entre outros), ecoam nos conceitos da organização empresarial, como o de "flexibilidade", assim também no discurso acerca dos comportamentos ideais do indivíduo na gestão de seu trabalho e na

\footnotetext{
${ }^{64}$ SPINK, Mary Jane P. Cérebro, self e sociedade: uma conversa com Nikolas Rose. Physis-Revista de Saúde Coletiva, v. 20, n. 1, p. 301-324, 2010, p. 312.

${ }^{65}$ ROSE, Nikolas \& ABI-RACHED, Joelle. Neuro: the new brain sciences and the management of the mind. Princeton: Princeton University Press, 2013, p. 9.

${ }^{66}$ Cf. AZIZE, Rogério A nova ordem cerebral: a concepção de 'pessoa' na difusão neurocientífica. Tese de doutorado em Antropologia Social, Museu Nacional, 2010.
} 
gestão de sua vida (que inclui o cuidado em desenvolver seu cérebro), como a ideia de "motivação", maleabilidade, incremento via exercício etc: "O cérebro seria, então, uma espécie de espelho daquilo que se espera do indivíduo no capitalismo contemporâneo: plástico, adaptável, presta-se a desafios, passível de ser melhorado"67.

É Ehrenberg, no entanto, que compreende de maneira mais aprofundada (1) as expectativas que pairam sobre os indivíduos na sociedade contemporânea - as quais Azize identifica como sendo espelhadas nos discursos sobre o cérebro - e, a partir do modo como eles se relacionam com elas, (2) o porquê da concepção neurocientífica de sujeito haver alcançado tamanho alcance social.

Como já adiantei, em $O$ sujeito cerebral, Ehrenberg enxerga um programa "fraco" e um programa "forte" de neurociências. Este último é dividido pelo sociólogo francês em três perspectivas. A perspectiva teórica é filosoficamente materialista, sendo para ela o cérebro o fundamento exclusivo do espírito. Essa visão se desdobra em uma perspectiva prática (profissional e terapêutica), com a aproximação e a fusão entre neurologia e psiquiatria, objeto, segundo o autor, de numerosos artigos, bem como de incontáveis resumos em que, por exemplo, o Alzheimer e as esquizofrenias são tratados sob o mesmo conceito de "doença"68. Esse "passo a mais", na direção de abordar também as ações e as relações sociais bem como fenômenos que indiscutivelmente possuem uma dimensão psíquica flagrante, é considerado por ele um "passo demais"69, o que nos leva a uma terceira perspectiva do programa forte: a social, já que em suas palavras, "o cérebro não pode mais ser considerado apenas um objeto médico e científico", pois "foi promovido também a um ator social"”70. Embora causando certo estranhamento com a ideia fetichizada de o cérebro ser encarado como ator/agente social, Ehrenberg lança uma série de questões precisas para a problematização sociológica do sucesso do programa forte da neurociência:

[...] em que medida a referência ao cérebro para descrever e compreender os comportamentos sociais é suscetível de entrar na linguagem comum? O cérebro pode ser - e em que condições - um objeto de identificação, um meio de se reconhecer como um agente social? [...] A opinião pública está em vias

\footnotetext{
${ }^{67}$ AZIZE, Rogério A nova ordem cerebral: a concepção de 'pessoa' na difusão neurocientifica. Tese de doutorado em Antropologia Social, Museu Nacional, 2010, p. 255

${ }^{68}$ Cf. EHRENBERG, Alain. O sujeito cerebral. Psicologia Clínica, Rio de Janeiro, vol.21, 2009, p.189.

${ }^{69}$ Ibidem, p. 194

${ }^{70}$ Ibidem, p. 189
} 
de adotar a ideia de que nossas dificuldades relacionais e psicológicas não são pessoais, mas neuroquímicas? Trata-se de uma metáfora? De uma vã proclamação à qual ninguém adere verdadeiramente? De uma nova linguagem para justificar nossos atos, suscetível de se difundir socialmente? É o que se deve explorar. ${ }^{71}$

Sobretudo na última questão é que se encontra implícita a interpretação do autor a respeito do sucesso de alcance e adesão da visão naturalista de sujeito da neurociência: deve-se ela a uma transformação da gramática moral de nossa existência, da linguagem pela qual nos orientamos e nos interpretamos como indivíduos.

No entanto, tal ideia não é bem desdobrada no supracitado artigo sobre o sujeito cerebral, sendo mais bem explicitada em pelo menos duas outras oportunidades, ambas anteriores: em uma entrevista dada a Michel Botbol; e em seu La Fatigue d'être soi: Dépression et société, obra em que relaciona a atual epidemia de depressão com essa mesma transformação normativa.

Ehrenberg diz a Botbol, que a década de 1970 marca a "passagem de uma sociedade que se refere à disciplina (interdição, obediência, autoridade, etc.) para uma sociedade que se encontra sob o primado da autonomia"72. A noção de autonomia coloca em jogo a questão da ação e do desempenho pessoais; isso porque se trata de um critério por meio do qual somos medidos, de uma norma pela qual nos guiamos, de uma nova linguagem, que como ele mesmo diz, "é alguma coisa normativa, que implica expectativas". Assim sendo, a noção de autonomia implica que "hoje em dia, trata-se de socializar pessoas que possam decidir e agir por si mesmas, como uma totalidade"73.

Em La Fatigue d'être soi: Dépression et société ${ }^{74}$, Ehrenberg discorre de maneira detalhada sobre o que entende como sendo essa guinada normativa e seus efeitos sobre o indivíduo - tendo como pano de fundo a sociedade francesa. Para ele: “tornamo-nos indivíduos no sentido mais puro, como não há lei moral ou tradição que possa nos dizer que devemos ser e como precisamos nos comportar" ${ }^{\text {,75. }}$.

\footnotetext{
${ }^{71}$ EHRENBERG, Alain. O sujeito cerebral. Psicologia Clínica, Rio de Janeiro, vol.21, 2009, p. 189-190.

72 EHRENBERG, Alain; BOTBOL, Michel. Depressão, doença da autonomia. Rio de Janeiro, v. 7, n. 1, 2004, p. 147.

73 Ibidem, p. 151.

${ }^{74}$ Cf. EHRENBERG, Alain. La Fatigue d'être soi: Dépression et société, Paris: Odile Jacob, 1998.

${ }^{75}$ Ibidem, p. 14, tradução nossa.
} 
A moderna democracia, assim, nos fez pessoas sem guias, colocando-nos em situações nas quais devemos julgar o que nos rodeia usando a nós mesmos como medida; construindo, portanto, nossas próprias referências ${ }^{76}$.

Hoje, somos donos de nós mesmos e não servos dóceis do príncipe, somos indivíduos soberanos, e ainda que esteja ciente de que esta soberania não significa um indivíduo todo-poderoso, Ehrenberg enxerga na centralidade do indivíduo encarado como uma totalidade, a base para o retorno do ator à cena política. Embora, como será discutido em breve, afirme que tal mutação normativa tenha feito da depressão o malestar da atualidade, enxerga este desenvolvimento da "gramática social" como um momento de perturbação das referências políticas e dos modos de ação públicas que permitirá a descoberta de uma nova identidade, de novos referenciais no contexto do individualismo de massa e da abertura das sociedades nacionais na era da globalização ${ }^{77}$.

O indivíduo, não mais regulado pelas disciplinas, passa a pautar suas ações por uma unidade interna, por capacidades mentais. Na atualidade, as noções de projeto, comunicação e motivação erigem-se em normas, as quais compreendem tanto o âmbito profissional como o da reabilitação ${ }^{78}$. No plano objetivo a iniciativa sucedeu à disciplina, enquanto no plano subjetivo a culpa deu lugar à responsabilidade ${ }^{79}$. O indivíduo deve se construir a todo tempo, deve infatigavelmente decidir por si mesmo, como uma totalidade, e é o único responsável por aquilo que faz de si. Ehrenberg assevera: "O homem soberano, que é apenas como ele, que Nietzsche tinha imaginado, agora se tornou a norma" $" 80$.

Tal pensamento me força a estabelecer um parêntese, pois ainda que Ehrenberg não o faça, sua discussão relembra um tema básico de toda a teoria sociológica. É impossível não lembrar de uma máxima durkheimiana: “[...] como não há nada no indivíduo que lhe possa fixar um limite, estes lhes deve necessariamente vir de alguma força exterior ao indivíduo[...]" ${ }^{\prime 81}$. Todavia, se bem compreendo Ehrenberg, é justamente esta força moral, exterior, normativa que deveria fixar uma direção, um limite, ou coisa

\footnotetext{
${ }^{76}$ EHRENBERG, Alain. La Fatigue d'être soi: Dépression et société, Paris: Odile Jacob, 1998, p. 14.

${ }^{77}$ Ibidem, p. 13.

${ }^{78}$ Ibidem, p. 14

${ }^{79}$ Ibidem, p. 15

${ }^{80}$ Ibidem, p. 13, tradução nossa.

${ }^{81}$ DURKHEIM, Emile. O Suicídio. São Paulo: Martins Fontes, 2000, p 315.
} 
que o valha, que na sociedade contemporânea delega ao indivíduo a tarefa de se limitar, de escolher suas referências diante da multiplicidade que chega até ele.

Esta empreitada individual, que do indivíduo parte e a ele se destina, é inalcançável, uma vez que nada exterior venha a regulá-la, o que lembra Emile Durkheim ao dizer que seja qual for o prazer que o homem experimenta em agir, moverse, ou esforçar-se, "é preciso que ele sinta que seus esforços não são vãos e que andando ele avança", o que não acontece "quando não andamos na direção de nenhum objetivo ou, o que dá na mesma, quando o objetivo na direção do qual andamos está no infinito" $"$.

Parece contraditório, mas a própria norma leva à anomia, e não a sua ausência, o que se coaduna com a constatação de Durkheim de que a anomia, já lá no final do século XIX, encontrava-se em estado crônico. A desregulamentação da vida social não deve mais ser encarada como patologia, mas como traço constitutivo da contemporaneidade, pelo menos nos atendo ao que Ehrenberg faz pensar.

Contudo, é preciso tomar cuidado: ele não nos diz que as referências das ações estejam ausentes, perdidas ou suspensas; mas que experimentamos tal sentimento de desregulamentação dado o aumento destas referências, sem as quais não haveria liberdade $^{83}$. No entanto, se ausentes ou se diversas, o resultado é o mesmo: o enfraquecimento da ideia de interdito, certa desregulamentação da ação e a consequente perda de espaço da noção de conflito como base da subjetividade ${ }^{84}$.

Assim sendo, para ele as formas atuais de mal-estar estão atreladas a uma sobrecarga individual, a uma longa aventura do individuo em busca de tornar-se si mesmo, para a qual há um repertório infinito de referências, de valores da concorrência econômica à competição esportiva, multiplicidade esta que faz com que o indivíduo sinta o percorrer de sua trajetória em busca de sua identidade pessoal como uma solitária e sempre distante autorrealização. Desamparado, exigindo de si a todo tempo, sendo avaliado por sua iniciativa e não por sua docilidade, o indivíduo se depara com um avassalador sentimento de insuficiência, de estar sempre aquém, de nunca estar à altura. A depressão é uma "tragédia do fracasso, a sombra familiar do homem sem guia"

\footnotetext{
${ }^{82}$ DURKHEIM, Emile. O Suicídio. São Paulo: Martins Fontes, 2000, p. 314.

${ }^{83}$ EHRENBERG, Alain. La Fatigue d'être soi: Dépression et société, Paris: Odile Jacob, 1998, p. 13.

${ }^{84}$ Ibidem, p. 16.
} 
cansado da empresa de ser si mesmo ${ }^{85}$. A base da subjetividade agora é da ordem da insuficiência, e não mais da ordem do conflito, da interdição, da contradição.

Voltando à discussão de $O$ sujeito cerebral, é nesse contexto social de imensa e intensa responsabilização individual, que acaba por acarretar sentimentos arrebatadores de insegurança e insuficiência, que as neurociências ganham terreno, segundo Ehrenberg.

Seu sucesso popular se relaciona menos com os resultados científicos e práticos obtidos até o momento e mais com o estilo de resposta capaz de oferecer aos problemas enfrentados pelo indivíduo contemporâneo. A causa específica do sucesso da visão neurocientífica de homem encontra-se no fato de que o sofrimento e a saúde mentais se tornaram o eixo dos processos contemporâneos de subjetivação, dada a incapacidade decisória do sujeito e o respectivo padecimento individual na sociedade da autonomia generalizada. As neurociências são a "ponta científica e tecnológica" da ideia de saúde mental:

\footnotetext{
Elas permitem, hoje, consolar quem - na realidade, a maioria de nós - tem dificuldade de encarar o mundo de decisão e ação que se edificou sobre as ruínas da sociedade da disciplina, aquela que conhecia o respeito à autoridade cuja perda é objeto de lamentações cotidianas. Mas as neurociências suscitam também a esperança de que sejam dadas a todos técnicas de multiplicação das capacidades cognitivas e de controle emocional, igualmente indispensáveis a tal estilo de vida ${ }^{86}$
}

No entanto, cabe indagar: o abismo que se encontra entre a autonomia experimentada no plano normativo e a sempre distante autorrealização é uma simples consequência da multiplicação das possibilidades de escolha dos referenciais para a ação ou, mais que isso, tem a ver com algo que extrapola a normatividade, com a dinâmica concreta e efetiva da reprodução social, com um modo de vida determinado, do qual a norma da autonomia seja apenas uma "aparência socialmente necessária" ou mesmo uma "falsa consciência"? Eis a raiz problemática da análise de Ehrenberg: tudo se passa no reino isolado da normatividade.

\footnotetext{
${ }^{85}$ EHRENBERG, Alain. La Fatigue d'être soi: Dépression et société, Paris: Odile Jacob, 1998, p. 17, tradução nossa.

${ }^{86}$ EHRENBERG, Alain. O sujeito cerebral. Psicologia Clínica, Rio de Janeiro, vol.21, 2009, p. 202.
} 
O mérito da análise de Ehrenberg está em sua consciência de que não é possível compreender a ascensão das neurociências sem observar o indivíduo de que elas falam, sem observar o modo em que se apresenta historicamente a relação entre ele e a sociedade, as questões que lhe surgem desta relação e que as neurociências o ajudam a enfrentar. No entanto, o autor se concentrou demasiadamente na questão normativa, por assim dizer, nos aspectos ideológicos da contemporaneidade. Ao estabelecer, de modo arbitrário, a normatividade social como o centro de sua "antropologia do individualismo", Ehrenberg credita a ela um valor objetivo que talvez ela não tenha.

Mesmo com todas as ressalvas, Ehrenberg acaba tratando a "autonomia" como algo dado, quando muito talvez não passe de uma promessa. Ao acionar a cláusula coeteris paribus, perde de vista outras dimensões sociais da nossa existência com as quais se relaciona e das quais depende a dimensão normativa. Ao restringir-se propositadamente ao viés da normatividade, da transformação da linguagem pela qual somos medidos, Ehrenberg desconhece outras dimensões da realidade social às quais estas configurações normativas servem, atingem, correlacionam-se etc., desconsiderando deliberadamente aquilo que é medido e em função do quê o é. O autor não observou as condições concretas de existência do indivíduo: "O que me interessou foram estas transformações normativas, e não a realidade pessoal ou clínica de meus contemporâneos" $" 87$.

Em resumo, ele não levou em conta as qualidades reais do sujeito contemporâneo no que concerne desde a configuração de sua psique até os seus determinantes sociais e históricos, os quais, obviamente, não se limitam ao plano normativo, apenas.

A visão de Ehrenberg é muito estanque, de um lado uma linguagem naturalista, de outro um indivíduo sofrendo por ser responsável por si próprio, "armado" com sua autonomia, mas sem saber ao certo o que fazer com ela. $\mathrm{O}$ que um tem a ver com o outro? O que a representação tem a ver com o objeto representado? O que a representação tem a ver com o mundo em que vive o objeto representado? Ehrenberg entende bem o motivo de os sujeitos se casarem com o discurso, ele observa bem que há um encaixe, mas as condições de produção tanto de um como de outro ele não dá conta

\footnotetext{
${ }^{87}$ EHRENBERG, Alain; BOTBOL, Michel. Depressão, doença da autonomia. Rio de Janeiro, v. 7, n. 1, 2004, p. 151.
} 
de compreender. Faltam à sua análise, materialidade e dialética, já que "nem a importância de um problema, nem a de uma teoria são independentes do estado da história e do papel que um homem desempenha dentro dela" ${ }^{\natural 8}$, sobretudo quando o problema e a teoria falam a respeito do que seja esse homem.

As questões lançadas há algumas páginas permanecem de pé e podem ser traduzidas em outros termos. O que possibilita a ascensão de tais teses? Em que se sustenta a adesão massiva dos homens a elas? Quais as causas da afinidade eletiva vista por Azize? Por que a linguagem neurocientífica se presta muitíssimo bem ao papel de conferir ao mesmo tempo significado e alento aos dilemas da existência individual na contemporaneidade, como enfatiza Ehrenberg? Tais dilemas e suas causas são mesmo oriundos da norma da autonomia? São os sujeitos de fato autônomos?

Para responder a essas questões, é necessário refletir sobre os tais dilemas da existência individual, é preciso refletir sobre o indivíduo tal como de fato ele tem se desenvolvido no mundo atual. Sendo repetitivo: se as neurociências falam do homem, essa sua fala, essa sua visão não tem algo que ver com o próprio homem de carne e osso, concreto, efetivo, tal como este vive, age, se comporta em sua dia-a-dia, tal como este é pensado, encarado, tratado em outras esferas que não a da ciência, tais como a da economia, da família, da indústria da cultura, da política etc.? Se o indivíduo soberano de que fala Ehrenberg não é soberano, todo-poderoso, como o próprio alerta, o que é esse indivíduo? Como tem se dado sua relação com o mundo e quais os efeitos da dialética entre ele a sociedade sobre sua subjetividade, sobre sua psique?

Deve-se considerar o papel dos homens concretos em suas vidas efetivas na gênese e na recepção dessa nova concepção de sujeito, seja esse papel ativo ou passivo, consciente ou inconsciente, já que é lógico e razoável supor que o modo como se representa um objeto, e a própria representação, em alguma proporção tem a ver com o objeto em si e com seu contexto social e histórico como um todo, isto é, como algo que vai além do plano normativo.

Partindo, então, de um ponto de vista materialista, segundo o qual a práxis social determina tanto o sujeito efetivo como a representação desse sujeito na esfera do conhecimento e da cultura, objetiva-se discutir o sucesso da concepção neurocientífica

\footnotetext{
${ }^{88}$ HORKHEIMER, Max. História e psicologia. Em: Teoria Crítica: uma documentação, I, São Paulo: Perspectiva, 2012, p. 28.
} 
de sujeito tendo em vista "a conexão que subsiste entre a vida econômica da sociedade, o desenvolvimento psíquico dos indivíduos e as transformações que têm lugar nas esferas culturais [ciência, arte, direito etc.]"

Desse ponto de vista, os diferentes corpos discursivos e estratégias de poder, assim como as linguagens que ajudam o indivíduo a conferir sentido à sua existência e a gerenciar seu self,não são independentes de sua práxis efetiva, de sua situação concreta, dos padrões, possibilidades e limites sociais e históricos com os quais se depara ao tentar se desenvolver enquanto sujeito, e do grau de desenvolvimento psíquico que consegue atingir tendo em vista tais constrangimentos.

Por conseguinte, cabe desconfiar que não mudou apenas o tratamento reservado ao homem e à forma de governá-lo (como entendem Rose e Abi- Rached), bem como a gramática moral de sua existência (interpretação de Ehrenberg), assim como não se trata de uma mera questão de afinidade entre diferentes corpos discursivos (como afirma Azize). Desconfio que antes o próprio homem tenha mudado, na medida em que foram transformadas suas condições de existência, para que essa "nova" concepção pudesse ter ressurgido e se revitalizado no âmbito científico e, por outro lado, pudesse ter sido ampla e positivamente recepcionada pelos próprios sujeitos na esfera da cultura.

Ao criticar a ascensão da concepção neurocientífica de homem (e o fato dela aderir semanticamente ao sujeito sem muita resistência da parte deste último) estou criticando, ao mesmo tempo, portanto, a sociedade em que ela ocorre (aquilo que essencialmente a caracteriza) e o estado efetivo dos sujeitos nesse período social (objetos do capítulo II) e, mais do que isso, estou alertando para os perigos de seus equívocos e para os efeitos negativos de sua ampla e irrefletida aceitação (capítulo III).

\footnotetext{
${ }^{89}$ HORKHEIMER, Max. A presente situação da filosofia social e as tarefas de um Instituto de Pesquisas Sociais. Praga, estudos marxistas, 1999 [1931], p. 130.
} 


\section{Capítulo 2}

\section{A expropriação psicológica do sujeito no capitalismo tardio e o sucesso da concepção neurocientífica de homem}

A chave para a explicação sociológica da gênese (no campo restrito da ciência) e da recepção (fora dos laboratórios) da concepção de homem das neurociências encontra-se, portanto e em larga medida, na investigação da situação da individualidade na sociedade contemporânea. Esse é o caminho escolhido para abordar o tema da cerebralização do sujeito, pois sendo de uma representação de homem que as neurociências nos falam, é o próprio homem, jamais apartado de suas condições materiais de existência, que devemos contrapor à representação. Sendo mais preciso, devemos contrapor a essa representação de homem a formatação social da percepção (neuro) científica e a formatação social do objeto percebido por ela - o sujeito contemporâneo.

Alain Ehrenberg não se engana quando nota que o indivíduo hoje, em um tempo de individualismo vigoroso, é mais do que nunca normativamente responsabilizado por suas ações e escolhas, embora (e aí Ehrenberg deixou a desejar) seja necessário perceber que quanto mais se fala em indivíduo, quanto mais importância se atribua a ele, menor sua real importância na dinâmica social, menor o desenvolvimento de sua individualidade: "quanto menos são os indivíduos, tanto maior o individualismo"90. O erro de Ehrenberg é do mesmo tipo do das neurociências: tomar o suposto como posto.

De modo contrário ao sociólogo francês, não circunscrevo a análise do estatuto do sujeito unicamente à dimensão normativa; estendo-a à análise das condições materiais de existência e formação dos sujeitos na sociedade capitalista tardia. Ancorado na visão dos frankfurtianos (sobretudo de Max Horkheimer e Theodor Adorno, todavia em alguma medida também de Herbert Marcuse), compreendo a atual condição do indivíduo como capítulo recente da secular história da luta humana pela sobrevivência, a história do desenvolvimento da Civilização.

90 ADORNO, Theodor; HORKHEIMER, Max (orgs.). Temas básicos da sociologia. São Paulo: Cultrix/Editora da Universidade de São Paulo, 1973[1956], p.53. 
É do indivíduo que irei falar e da dinâmica social da qual ele (embora "participe") é hoje refém, que, pelas mais variadas mediações, a contemporânea ciência do cérebro retira a "forma" (a racionalidade) e a "substância" (o estado em que o sujeito é percebido) de sua concepção de homem. Logo, cumpre discorrer brevemente a respeito da dialética entre indivíduo e sociedade no processo de reprodução social para em seguida analisar suas características no presente histórico, servindo-me do pensamento dos frankfurtianos.

Entende-se por indivíduo, um ser humano com uma existência sensível e consciente (espaço-temporalmente condicionada) capaz de reconhecer sua própria identidade, isto é, perceber a si mesmo como um $E u$, diferenciando-se de seus semelhantes. Alguém com uma história, com um passado, com uma trajetória particular e significativa, com suas fantasias, sonhos e fantasmas próprios.

O desenvolvimento subjetivo se dá em função da incorporação da cultura, entendida não como a vida espiritual encerrada em si mesma, mas como algo entrelaçado e dependente tanto da natureza quanto da vida econômica da sociedade, de modo que "o indivíduo plenamente desenvolvido é a consumação de uma sociedade plenamente desenvolvida" 91 .

A individualidade, disse Max Horkheimer, "pressupõe o sacrifício voluntário da satisfação imediata pelo bem da segurança, da manutenção material e espiritual da própria existência"92. A formação de indivíduos diferenciados e conscientes dessas diferenças necessita, portanto, de uma base material estável que não coloque em dúvida a sobrevivência de quem quer que seja e que possibilite a todos o afastamento relativo da tradição, dos grupos e da sociedade em geral e o consequente cultivo permanente e jamais ameaçado de traços individuais, de uma história pessoal.

Tal identificação entre indivíduo e sociedade encontra-se, porém, no futuro. Até aqui a essência da individualidade consiste na tomada de consciência de que há uma contradição entre ela e as coerções econômicas e sociais, de que não há identidade entre particular e universal ${ }^{93}$. No entanto, os caminhos para tal percepção parecem bloqueados atualmente e, longe de terem consciência do antagonismo entre suas

\footnotetext{
${ }^{91}$ HORKHEIMER, Max. Eclipse da Razão. São Paulo: Unesp, 2015 [1947], p. 150.

92 Ibidem, p. 144

${ }^{93}$ Ibidem, p.146-147.
} 
aspirações mais elementares e as exigências da totalidade, os homens se entregam cegamente ao desejo de adaptação à realidade, processo "sintomático da crise presente do indivíduo"94.

Esses dois movimentos desigualmente possíveis encerram dois modos diametralmente opostos de pensamento no que concerne à relação entre indivíduo e sociedade, logo, também ao tema da formação subjetiva. De um lado, indivíduo e sociedade se identificam: forma-se unilateralmente para o mundo tal como ele é; voltase para adaptação ao existente, para a falsa conciliação entre indivíduo e sociedade tal como aparece na crença liberal de que o progresso do todo é reflexo do sucesso individual, quando há muito o interesse particular é inautêntica e inteiramente do todo. De outro lado, rompe-se com a lógica identificatória, passando "o caráter discrepante cindido do todo social [...] a ser contradição consciente"95, direcionando o pensamento para a crítica, para o negativo, para o que pode ser e não é.

O limite do princípio da identificação se encontra no fato de que a identificação entre indivíduo e sociedade (dada a forma como vem se dando a tentativa de sua consumação ao longo dos séculos) não é algo necessariamente satisfatório para o indivíduo, como discutiu Sigmund Freud em $O$ mal-estar na civilização ${ }^{96}$, nem algo automaticamente dado, mas uma esperança ainda não realizada, um produto histórico ainda a ser alcançado e que sob o pretexto de já ser efetivo, converte esta pretensa e falsa identificação em desprezo e violência para com o particular, para com o indivíduo e suas paixões, tal qual criticaram Theodor Adorno e Max Horkheimer. "A identidade", disse Adorno em um de seus aforismos intitulado Pela Metade, "repousa na não identidade, no ainda não ocorrido, que denuncia aquilo que ocorreu" $" 97$, o ocorrido sendo o horror sem fim, e sua negação consistindo na ideia do desenvolvimento da autonomia e da concreta realização da felicidade dos indivíduos em uma sociedade livre e efetivamente esclarecida.

$\mathrm{Na}$ interpretação de Alain Ehrenberg, a contemporaneidade produziu um indivíduo soberano, avaliado não pela sua obediência, mas por sua capacidade de

\footnotetext{
94 HORKHEIMER, Max. Eclipse da Razão. São Paulo: Unesp, 2015 [1947], p. 147.

95 HORKHEIMER, Max. Teoria tradicional e Teoria crítica, p. 44.

96 Cf. FREUD, Sigmund. O mal-estar na civilização, novas conferências introdutórias sobre a psicanálise e outros textos (1930-1936). São Paulo: Companhia das Letras, 2010.

97 ADORNO, Theodor. Minima Moralia: reflexões a partir da vida lesada. Rio de Janeiro: Azougue, 2008, p. 232.
} 
autorrealização. Livre de uma densa cadeia de coerções, sua subjetividade é erigida não mais na base do conflito entre suas aspirações e as exigências da totalidade social, mas a partir de sua capacidade individual de agir e decidir, pelo desempenho da qual é permanentemente responsabilizado. Não havendo mais regulação da vida social, gozando o indivíduo da norma da autonomia, o conflito se ausenta tanto da dimensão social quanto da psíquica.

Pode-se dizer que, do ponto de vista subjetivo, Adorno e Horkheimer também observam que o conflito entre indivíduo e sociedade já não é mais experimentado como tal, já que a relação entre eles não é mais vivida como sendo antagônica. Entretanto, são justamente as razões da ausência de percepção dos antagonismos que diferenciam radicalmente a perspectiva de Alain Ehrenberg (que está na base de sua compreensão do fenômeno da cerebralização do sujeito) do diagnóstico do presente histórico compartilhado pelos frankfurtianos (o qual serve de fundamento para a minha crítica $d a$ cerebralização). Para um não há mais conflito porque não há mais regulação. Para os outros, apoiados na ideia central de que o progresso da racionalização da sociedade traz em si mesmo o germe da regressão, pode-se dizer que porque a regulação é excessiva, atingindo os recônditos da existência individual, incapacitada de resistir, de salvaguardar algum vestígio de autonomia e espontaneidade ante o compêndio de comportamentos padronizados exigidos e inculcados desde as fases iniciais da vida.

Quando não há regulação, como entende Ehrenberg, não há conflito. Porém, contudo, todavia, quando a regulação é excessiva, dá-se o mesmo. A ausência de conflito diz respeito, portanto, ao movimento histórico-social contemporâneo "em direção à integração total" do qual nos falam os frankfurtianos ${ }^{98}$. No que se pode chamar de mundo administrado, a regulação social é insidiosa: os indivíduos são expropriados psicologicamente, tornando-se indiferentes, iguais uns aos outros, cada um preocupado em se preservar, o que significa se adaptar o melhor possível ao mundo tal como ele é.

A eficiência, a capacidade de ação e decisão de que tanto fala Ehrenberg, " [...] é inerente à habilidade de ser 'um dos caras', de garantir o seu, de impressionar os outros, de 'vender-se', de cultivar as conexões certas [...]", no limite, de se entregar e se

\footnotetext{
98 ADORNO, Theodor \& HORKHEIMER, Max. Dialética do esclarecimento. Rio de Janeiro: Jorge Zahar. $2^{\text {a }}$ edição, 2006 [1947] p. 9.
} 
integrar $^{99}$. O conflito se ausentou porque a dominação se tornou mais econômica. $\mathrm{O}$ indivíduo que era palco de um conflito interno ainda assim preservava um pouco de autonomia, de motivação própria e por isso resistia mais. O sujeito de hoje acata diretamente as ordens, identifica-se imediatamente com a realidade; não há qualquer desperdício, qualquer ônus para a administração. Em suma, o conflito não existe mais porque os mecanismos de dominação evoluíram, e não porque o homem goza de mais autonomia. Ainda na década de 1940, Adorno e Horkheimer não hesitaram em dizer que "seria digna de escárnio uma sociedade que conseguisse transformar os homens em indivíduos" $" 100$.

As duas grandes obras em que se encontra de maneira mais bem desenvolvida a compreensão desses autores acerca desse mundo administrado que se tornou a sociedade contemporânea são a Dialética do Esclarecimento e o Eclipse da Razão. Como os próprios títulos evidenciam, tais obras tratam primordialmente do conceito de racionalidade subjacente a nossa cultura, de sua concretização e operação em nossas diversas instituições, examinando seus mais variados desdobramentos, entre eles, seu concurso para uma administração social da vida cada vez mais abrangente e seus respectivos efeitos sobre a individualidade, sobre a formação dos sujeitos.

Eis o ponto do qual eu devo partir: o diagnóstico dos frankfurtianos que versa sobre a transformação do sujeito em meados do século XX, transformação esta cujo aspecto essencial é o paradoxo da racionalização ${ }^{101}$ social sem precedentes que teve lugar no Ocidente, cujo efeito sobre o homem, por sua vez, aparece sintetizado em expressões como declínio do indivíduo, liquidação da subjetividade, coisificação da alma, expropriação psicológica e outras.

99 HORKHEIMER, Max. Eclipse da Razão. São Paulo: Unesp, 2015 [1947], p. 170-171.

100 ADORNO, Theodor \& HORKHEIMER, Max. Dialética do esclarecimento. Rio de Janeiro: Jorge Zahar. $2^{\mathrm{a}}$ edição, 2006 [1947], p. 24.

101 A associação do conceito weberiano de racionalização ao conceito de reificação (derivado da discussão de Marx a respeito do fetichismo da mercadoria em $O$ Capital) é original de Georg Lukács, que participou ativamente do círculo intelectual de Max Weber em Heidelberg, antes de se enveredar pelo marxismo. Cf. LUKÁCS, Georg. História e consciência de classe: estudos sobre a dialética marxista. São Paulo: Martins Fontes, 2003 [1923]. 


\section{A dialética da racionalização e a expropriação psicológica do sujeito no capitalismo tardio.}

Parece que enquanto o conhecimento técnico expande o horizonte do pensamento e da atividade do homem, sua autonomia como um indivíduo, sua capacidade de resistir ao crescente aparato de manipulação de massa, seu poder de imaginação, seu juízo independente são aparentemente reduzidos. $\mathrm{O}$ avanço nos meios técnicos de esclarecimento é acompanhado por um processo de desumanização. Assim, o progresso ameaça anular o próprio objetivo que ele supostamente deveria realizar - a ideia de homem.

Max Horkheimer, Eclipse da Razão, 1947

Da mesma forma que a mente, enquanto persevera em sua oposição à natureza, não é nada senão um elemento da natureza, também o indivíduo não é nada senão uma espécie biológica enquanto seja apenas a encarnação de um ego definido pela coordenação de suas funções a serviço da autopreservação.

Max, Horkheimer, Eclipse da Razão, 1947

A verdade da psicanálise nem por isso se enfraquece; pelo contrário, a obsolescência de seu objeto manifesta a que ponto o progresso foi, na realidade, repressão.

Já na época de sua maturidade a teoria freudiana exprimia mais o passado que o presente - uma imagem antes desbotada que universalmente triunfante do homem, uma forma de existência humana em desaparecimento.

Herbert Marcuse, A obsolescência da psicanálise, 1963.

O eu integralmente capturado pela civilização se reduz a um elemento dessa inumanidade, à qual a civilização desde o início procurou escapar.

Theodor Adorno e Max Horkheimer, Dialética do Esclarecimento, 1947. 
A iniciativa de Theodor Adorno e Max Horkheimer de elaborar um diagnóstico abrangente do presente histórico, nos anos 1940, deu-se devido à percepção crescente de que a racionalização da sociedade não vinha trazendo consigo a redução das injustiças e o desenvolvimento humano como era de se esperar, ao contrário, estava resultando em uma dominação cada vez mais insuportável sobre a vida das pessoas, como atestam a democracia massificada dos Estados Unidos e o recrudescimento do autoritarismo na Europa (na Itália, na Alemanha, mas também na União Soviética), cujo marco negativo foi a paranoia fascista e o extermínio "racional" de seres humanos em escala industrial.

O problema a ser investigado por eles passou a advir do fato de que foi justamente no momento em que a racionalização social atingiu um patamar impensável que a barbárie irrompeu de forma estridente. A emergência do irracional no seio do progresso da racionalização fez com que a própria racionalidade se tornasse objeto do crivo crítico dos frankfurtianos.

O interesse em um modo de vida racional nunca deixou de caracterizar as suas intenções, porém Adorno e Horkheimer perceberam que a racionalidade sobre a qual se instaurou o desenvolvimento da sociedade nos últimos séculos estava indissoluvelmente associada à dominação (da natureza e do homem sobre o homem, incluindo a do indivíduo sobre si mesmo) e à reificação da sociedade e da própria subjetividade, de modo que seria necessário que essa racionalidade acolhesse a reflexão acerca de sua dimensão regressiva para que o mundo pudesse efetivamente progredir rumo a um modo de vida verdadeiramente racional.

As reflexões a respeito da tendência destrutiva do progresso, da autodestruição do esclarecimento, são encontradas em sua forma mais bem acabada na Dialética do Esclarecimento $^{102}$, obra conjunta de Theodor Adorno e Max Horkheimer, e no Eclipse da Razão ${ }^{103}$, de autoria de Max Horkheimer ${ }^{104}$. Nessas obras, o diagnóstico do presente histórico é propositalmente alargado. O escopo da crítica da razão - que visa escavar

${ }^{102}$ Cf. ADORNO, Theodor \& HORKHEIMER, Max. Dialética do esclarecimento. Rio de Janeiro: Jorge Zahar. $2^{\mathrm{a}}$ edição, 2006 [1947].

${ }^{103}$ Cf. HORKHEIMER, Max. Eclipse da Razão. São Paulo: Unesp, 2015 [1947].

${ }^{104}$ No prefácio do Eclipse, obra levada a cabo apenas por Horkheimer (a partir dos manuscritos de palestras ministradas por ele na Universidade de Columbia, em 1944), este também atribui a Adorno seu conteúdo: "Seria difícil dizer quais ideias originaram-se na mente dele [Adorno] e quais na minha; nossa filosofia é uma só". Não é raro encontrar quem considere o Eclipse uma versão mais acessível das teses da Dialética do Esclarecimento. 
seus aspectos soturnos - é nada mais nada menos que a história da civilização e da constituição do sujeito até sua chegada à sociedade capitalista tardia.

Durante longo tempo predominou socialmente uma racionalidade que não é apenas uma faculdade do sujeito, mas algo peculiar ao mundo objetivo, à natureza, à relação entre os homens e às instituições sociais. Presente nos grandes sistemas filosóficos, sua ênfase recai sobre a discussão acerca dos fins - o que é belo, o que é bom, o que é verdadeiro, o que é justo etc. - mais do que acerca dos meios ${ }^{105}$. Diametralmente oposto, o conceito de racionalidade atualmente predominante advém "da faculdade de classificação, inferência e dedução", isto é, do "mecanismo abstrato do pensamento", não importando o conteúdo particular ou os propósitos da ação que se pretende racional $^{106}$. Reduzindo-se ao cálculo que visa à correta adequação entre os meios e os fins perseguidos por uma ação (independente do valor objetivo do seu conteúdo), a razão atende em última instância ao interesse de autopreservação do sujeito, sendo um instrumento seu na luta pela vida ${ }^{107}$, o que a configura, portanto, como formal, abstrata, instrumental e, acima de tudo, subjetiva.

Ambas as figuras da racionalidade representam diferentes facetas de um mesmo fenômeno que se pode chamar de razão ou de esclarecimento. Não se trata de coisas apartadas e indiferentes uma à outra. A grande questão reside no fato de que, sobretudo a partir do Renascimento, o esclarecimento tem se desenvolvido unilateralmente como instrumento de preservação do sujeito ou, o que lhe equivale, como meio de dominação, seja da natureza, seja de outros homens. Vale o alerta de que na Dialética do Esclarecimento não ocorre essa apresentação dicotômica da racionalidade, à qual Horkheimer recorre no Eclipse talvez para fins "didáticos", visto que os capítulos do livro foram inspirados em conferências proferidas por ele na Universidade de Columbia, em 1944. O esclarecimento é um só, é uma unidade dialética: o problema é ele não se dar conta da sua tendência regressiva, de seu pacto com a dominação dos homens e da natureza externa, o que ocorre quando é reduzido a um instrumento do sujeito, tendo ignorada a sua dimensão objetiva.

Esse exercício específico do pensamento (a subjetivação da razão) está entrelaçado, portanto, à necessidade material de dominação da natureza, tendo em vista

\footnotetext{
${ }^{105}$ HORKHEIMER, Max. Eclipse da Razão. São Paulo: Unesp, 2015 [1947], p. 12-13.

${ }^{106}$ Ibidem, p.11-12.

${ }^{107}$ Ibidem, p. 12.
} 
a conservação do sujeito e a reprodução da sociedade. Seu programa é o "desencantamento do mundo" pelo qual a imaginação é substituída pelo saber, investindo o homem na posição de senhor. Esse programa encontra-se, hoje, sob a responsabilidade técnica da ciência moderna que renuncia ao sentido e substitui "o conceito pela fórmula, a causa pela regra e pela probabilidade"108, em outras palavras, abstrai as particularidades dos objetos para apreendê-los por sua unidade formal, levando a que a ciência domine a natureza desencantada e incapacitada de resistir.

Tal modo de conceber e desenvolver a racionalidade é inseparável do processo civilizador e do advento da modernidade capitalista. Mais do que uma mera relação, ele vincula-se ao capitalismo como um dos pressupostos históricos fundamentais de seu pleno funcionamento.

Por conseguinte, a discussão sobre a racionalidade ou sobre o esclarecimento não se restringe unicamente ao domínio do conhecimento, mas engloba antes dele a história da própria humanidade em sua luta pela sobrevivência.

A dominação "racional" da natureza por meio da qual o sujeito sobrevive, o que hoje se faz por meio do trabalho dócil e obediente, tem um preço: o homem deve, antes de tudo, negar a si próprio, a seus sentidos, a suas pulsões e a suas fantasias, aquilo que há nele de particular, uma vez que tais aspectos o afastam do conhecimento objetivo e do respectivo domínio do seu entorno. Esse autodomínio, no entanto, é a "destruição virtual do sujeito a serviço do qual ele ocorre" ${ }^{109}$, pois negando a si para se conservar, o sujeito da razão abstrata se embrutece, reifica-se, regride ao estado de mera coisa, ao passo que, ao mesmo tempo, reifica o objeto, já que este somente é apreendido pela unidade, tendo abstraído e esquecido o seu conteúdo particular não redutível ao uno.

A reificação do objeto (a "dominação na esfera do conceito"), portanto, tem como fundamento "a dominação do real" "110, isto é, a reificação da própria sociedade e do sujeito lutando para viver sob condições dadas social e historicamente.

Assim sendo, além da reflexão concentrada na esfera do conhecimento, a análise crítica da concepção de homem das neurociências reclama, por outro lado, a consideração da reificação na vida efetiva, ou seja, no movimento de reprodução da

\footnotetext{
${ }^{108}$ ADORNO, Theodor \& HORKHEIMER, Max. Dialética do esclarecimento. Rio de Janeiro: Jorge Zahar. $2^{\mathrm{a}}$ edição, 2006 [1947], p. 18.

${ }^{109}$ Ibidem p. 54.

${ }^{110}$ Ibidem, p. 25.
} 
sociedade e na transformação do sujeito tendo em vista tal movimento histórico, pois "somente a tomada de consciência do social proporciona ao conhecimento a objetividade que ele perde por descuido enquanto obedece às forças sociais que o governam, sem refletir sobre elas", sendo a crítica do conhecimento também crítica da sociedade $^{111}$.

Vejamos alguns aspectos dessa transformação do sujeito, em função da qual suponho que as representações a seu respeito também se transformaram.

No que toca ao pensamento de Adorno e Horkheimer acerca de nossa história mais próxima, trata-se da reflexão acerca da passagem do capitalismo concorrencial para o capitalismo monopolista, transição de uma ordem social fundada no livre mercado para uma nova ordem na qual o Estado passa a ter papel preponderante na organização da economia, seja nas democracias de massa, seja nos estados ditatoriais. Trata-se da transição para o mundo administrado, amplamente racionalizado, no qual o mercado autônomo e a livre iniciativa, que outrora haviam sido a base econômica da individualidade burguesa, cederam lugar às agências estatais de controle e às grandes corporações econômicas $^{112}$.

O período do liberalismo, do livre mercado, caracterizava-se "pela existência de uma multidão de empreendedores independentes, que tomavam conta de sua propriedade e a defendiam contra forças sociais antagônicas", que para isso aprendiam "do passado tudo o que podiam", formulavam "planos para o futuro", cultivando assim certa independência ao pensar. Embora já sofrendo os efeitos do princípio nivelador da troca, o sujeito liberal detinha certa margem de ação, inventividade e espontaneidade. "Sua individualidade era a do provedor, orgulhoso de si mesmo e dos seus"; sentia-se responsável por seu negócio, por sua vida e pela de sua família ${ }^{113}$.

O capitalismo do século XX guarda uma característica distintiva sobre a qual se detiveram: a partir da década de 1930, com a ascensão do autoritarismo e com a planificação e monopolização das mais distintas economias, o fenômeno da reificação se generalizou, deixando de ser uma realidade apenas do mundo da produção de

\footnotetext{
${ }^{111}$ ADORNO, Theodor. Sobre sujeito e objeto. Em: Palavras e Sinais - modelos críticos 2. Petrópolis: Editora Vozes, 1995 [1969], p. 189.

112 HORKHEIMER, Max. Eclipse da Razão. São Paulo: Unesp, 2015 [1947], p.154.

${ }^{113}$ Ibidem, p. 155.
} 
mercadorias para instalar-se nas esferas da cultura, do conhecimento e no âmago da própria subjetividade.

A espontaneidade, já bastante sufocada na era liberal, cedeu lugar então à passividade, e a ideia de responsabilidade se enfraqueceu. $\mathrm{O}$ indivíduo passou a sentir que sua vida dependia menos dele do que das disputas nacionais e internacionais "entre os colossos do poder" "114. A sociedade se tornou uma segunda natureza, mais enrijecida e inalcançável do que a primeira, uma verdadeira "floresta de cliques e instituições que, dos mais altos níveis de comando da economia até as últimas gangues profissionais, zelam pela permanência ilimitada do status quo"115.

$\mathrm{Na}$ época dos grandes negócios - momento em que o mercado mundial surge como a nova forma de destino - torna-se mais difícil planejar para os herdeiros e mesmo para o futuro imediato, de modo que o sujeito se vê acuado e sente que não estará inteiramente perdido caso se mantenha eficiente e adaptado aos grupos de que faz parte. Diante da forte ameaça e da constatação de sua fragilidade frente ao mundo administrado que, embora exista por suas mãos, coloca-se acima de sua cabeça, o conformismo torna-se um ideal per se e o sujeito entrega-se à completa assimilação ao mecanismo que o domina. Desde a tenra infância, é conduzido a crer que "há apenas um caminho para se dar bem neste mundo - desistir da esperança de autorrealização absoluta" "116. Desse modo, o sujeito tende a "tornar-se um ego encolhido, cativo do presente evanescente, esquecendo o uso de suas funções intelectuais pelas quais outrora era capaz de transcender sua real posição na sociedade" ${ }^{117}$.

A constituição histórico-subjetiva do indivíduo burguês e sua condição social atual estão, por conseguinte, fortemente relacionados ao desenvolvimento unilateral do esclarecimento enquanto instrumento de autopreservação e dominação, o qual "exprime o movimento real da sociedade burguesa como um todo sob o aspecto da encarnação da sua Ideia em pessoas e instituições"118.

\footnotetext{
${ }^{114}$ HORKHEIMER, Max. Eclipse da Razão. São Paulo: Unesp, 2015 [1947], p. 156.

115 ADORNO, Theodor \& HORKHEIMER, Max. Dialética do esclarecimento. Rio de Janeiro: Jorge Zahar. $2^{\mathrm{a}}$ edição, 2006 [1947], p. 43.

${ }^{116}$ HORKHEIMER, Max. Eclipse da Razão. São Paulo: Unesp, 2015 [1947], p. 156

${ }^{117}$ Ibidem, p. 156.

118 ADORNO, Theodor \& HORKHEIMER, Max. Dialética do esclarecimento. Rio de Janeiro: Jorge Zahar. $2^{\mathrm{a}}$ edição, 2006 [1947], p. 13.
} 
O esclarecimento é objetivo, material, está atrelado à realidade, e por isso possui efeitos que transcendem o gabinete e o laboratório, e eles não só estão entrelaçados à sociedade, à economia, à política e às instituições a elas ligadas, portanto, como atingem o próprio indivíduo socializado. "A racionalidade econômica, esse princípio tão enaltecido do menor meio, continua incessantemente a remodelar todas as unidades da economia: tanto a empresa, quanto os homens" ${ }^{\prime 19}$. A administração, logo a dominação, também se dá sobre os homens, sua subjetividade, seu corpo e sua psique, e seu "preço" é alto:

\footnotetext{
O preço da dominação não é meramente a alienação dos homens com relação aos objetos dominados; com a coisificação do espírito, as próprias relações dos homens foram enfeitiçadas, inclusive as relações de cada indivíduo consigo mesmo. Ele se reduz a um ponto nodal das reações e funções convencionais que se esperam dele como algo objetivo. ${ }^{120}$
}

Esta redução evidencia-se, entre outros exemplos, na rendição do indivíduo às estatísticas e às pesquisas probabilísticas acerca de seu comportamento na busca por um emprego, na escolha de um candidato, nas formas de consumo, etc. Como observa Horkheimer a respeito do indivíduo que vive tal realidade, sua vida a tal ponto segue um roteiro padronizado que se encaixaria perfeitamente em qualquer questionário que por ventura ele tivesse que completar ${ }^{121}$.

Hoje, os modelos e as resoluções macroeconômicas, os dispositivos matemáticos utilizados por livrarias e redes de comércio eletrônico, as pesquisas de mercado, etc., conseguem muitas vezes prever e ao mesmo tempo concretizar suas previsões sobre como os indivíduos se comportarão dentro de uma dada conjuntura. Reduz-se o IPI hoje, e mais homens compram carros amanhã. Reduzem-se os juros e mais se investe. As pesquisas eleitorais antecipam, dentro de uma pequena margem de erro, os resultados das eleições. Só pode ser previsível e estimado, nos mais diversos âmbitos, aquilo que já é reificado em alguma medida e, portanto, que não é dotado de motivação própria, que não é livre.

\footnotetext{
119 ADORNO, Theodor \& HORKHEIMER, Max. Dialética do esclarecimento. Rio de Janeiro: Jorge Zahar. $2^{\mathrm{a}}$ edição, 2006 [1947], p. 167.

${ }^{120}$ Ibidem, p. 35.

${ }^{121}$ HORKHEIMER, Max. Eclipse da Razão. São Paulo: Unesp, 2015 [1947], p. 176.
} 
Quanto às reações, as expectativas que repousam sobre ele são da ordem do conformismo, da submissão, da adaptação ao real, disposições indispensáveis para exercer sem resistência as funções que lhe cabem e que dele são esperadas: produzir e consumir, trabalhar e se entreter. O indivíduo, para eles, é submisso e adaptado, mera "célula de reação funcional"122:

Quanto mais complicada e mais refinada a aparelhagem social, econômica e científica, para cujo manejo o corpo já há muito foi ajustado pelo sistema de produção, tanto mais empobrecidas as vivências de que ele é capaz. Graças aos modos de trabalho racionalizados, a eliminação das qualidades e sua conversão em funções transferem-se da ciência para o mundo da experiência dos povos e tende a assemelhá-lo de novo ao mundo dos anfíbios ${ }^{123}$.

Nesse sentido, o diagnóstico do presente histórico levado a cabo pelos frankfurtianos é o de que o progresso cego e unilateral da racionalização (esclarecimento), em sua modalidade subjetiva e formal, criou um terreno para o desenvolvimento pleno do sujeito ao mesmo tempo em que produziu uma socialização radical, encetando novas e mais eficazes sujeições operadas por mecanismos técnicoadministrativos fetichizados que submetem e dominam igualmente a tudo e a todos (nas fábricas, nos escritórios, nas escolas, nos hospitais, no "tempo livre"), convertendo-se em seu contrário - na reificação do homem:

Pela mediação da sociedade total, que engloba todas as relações e emoções, os homens se reconvertem exatamente naquilo contra o que se voltara a lei evolutiva da sociedade, o princípio do eu: meros seres genéricos, iguais uns aos outros [...]. ${ }^{124}$

Como efeito do caráter exacerbadamente administrativo e totalitário da sociedade, ocorreu o que Horkheimer compreende, no Eclipse, como sendo o declínio do indivíduo. O sujeito foi esvaziado psicologicamente e sua economia psíquica passou a ser gerida racionalmente pela própria sociedade, seja pela indústria da cultura e do entretenimento na esfera privada, seja pelos mecanismos técnico-administrativos bem espalhados na esfera profissional:

\footnotetext{
${ }^{122}$ HORKHEIMER, Max. Eclipse da Razão. São Paulo: Unesp, 2015 [1947], p. 160.

123 ADORNO, Theodor \& HORKHEIMER, Max. Dialética do esclarecimento. Rio de Janeiro: Jorge Zahar. $2^{\mathrm{a}}$ edição, 2006 [1947], p. 41.

${ }^{124}$ Ibidem, p. 41.
} 
[...] na era das grandes corporações e das guerras mundiais, a mediação do processo social através das inúmeras mônadas mostra-se retrógrada. Os sujeitos da economia pulsional são expropriados psicologicamente e essa economia passa a ser gerida mais racionalmente pela própria sociedade. As decisões que o indivíduo deve tomar em cada situação não precisam mais resultar de uma dialética interna [de um conflito] da consciência moral, da autoconservação e das pulsões. Para as pessoas na esfera profissional, as decisões são tomadas pela hierarquia que vai das associações até a administração nacional; na esfera privada, pelo esquema da cultura de massa que desapropria seus consumidores forçados dos seus últimos impulsos internos As associações e as celebridades assumem as funções do ego e do superego, e as massas [...] deixam-se modelar muito mais docilmente segundo os modelos e palavras de ordem dadas, do que os instintos pela censura interna. Se, no liberalismo, a individuação de uma parte da população era uma condição da adaptação da sociedade em seu todo ao estágio da técnica, hoje, o funcionamento da aparelhagem econômica exige uma direção das massas que não seja perturbada pela individuação. A orientação economicamente determinada da sociedade em seu todo (que sempre prevaleceu na constituição física e espiritual dos homens) provoca a atrofia dos órgãos do indivíduo que atuavam no sentido de uma organização autônoma de sua existência. ${ }^{125}$

A indústria da cultura, aquela a que o homem se entrega em seu "tempo livre", tornou-se um sofisticado mecanismo de dominação social. O mundo inteiro é forçado a passar pelo filtro desta indústria cuja norma de produção é, a partir de técnicas avançadas, "reproduzir rigorosamente o mundo da percepção quotidiana" levando o espectador a perceber "a rua como um prolongamento do filme que acabou de ver"126. Ao conduzir o consumidor a uma identificação imediata com a realidade, a indústria cultural tem como efeito a atrofia da imaginação. Ela destitui o indivíduo de seus últimos impulsos espontâneos.

Tanto ela quanto os mecanismos administrativos da indústria e do Estado atuam como instâncias de controle da percepção que lhe negam "toda antecipação desejosa [e] por isso mesmo lhe impõe em cada caso o esquema da repetição impotente do já conhecido, [resultando] no sacrifício do intelecto"127. Se, como dissera tardiamente Adorno, "pensar é, já em si, antes de todo e qualquer conteúdo particular, negação,

${ }^{125}$ ADORNO, Theodor \& HORKHEIMER, Max. Dialética do esclarecimento. Rio de Janeiro: Jorge Zahar. $2^{\mathrm{a}}$ edição, 2006 [1947], p. 167-8.

${ }^{126}$ Ibidem, p. 104.

${ }^{127}$ ADORNO, Theodor. O sacrifício do intelecto. Em: Minima Moralia: reflexões a partir da vida lesada. Rio de Janeiro: Azougue, 2008, p. 119. 
resistência ao que lhe é impingindo"128 , os limites do pensamento atual e sua inclinação a reproduzir o status quo parecem indiscutíveis.

Essa tendência é tão agressiva que já em 1937, em Teoria Tradicional e Teoria Crítica, Horkheimer a enxerga atuando em vários setores do proletariado, fato que o levou a um progressivo afastamento mesmo dos setores progressistas da classe, transferindo o título de portador da negatividade ao indivíduo de comportamento e pensamento críticos ainda capaz de reconhecer a não-identificação entre sujeito e objeto, indivíduo e sociedade. Com a ascensão do nazismo e a acentuação do caráter administrativo da sociedade nas décadas posteriores, a submissão ao imediato erige-se em regra vital, de tal modo que a tendência à "integração" e a "identidade da inteligência e da hostilidade ao espírito encontraram uma confirmação avassaladora" ${ }^{129}$, reafirmam Horkheimer e Adorno no prefácio à edição alemã da Dialética do Esclarecimento, de 1969.

Adorno e Horkheimer afirmaram, então, em plena década de 1940, que como efeito da generalização da reificação por todas as instâncias sociais, o sujeito da psicanálise (do Isso, do Eu e do Supereu) entrou em declínio, foi expropriado psicologicamente. O sujeito-objeto que o sucedeu tem como característica um eи pouco desenvolvido e a ausência quase completa de um supereu, porque submetido à socialização imediata cedeu seu papel modelar diretamente aos códigos disseminados pela indústria cultural e pelas políticas administrativas da indústria e do Estado.

Em A Obsolescência da Psicanálise, conferência proferida em Nova Iorque, em 1963, durante reunião da American Political Science Association, Herbert Marcuse trata especificamente dessa transformação do sujeito no capitalismo tardio. Também para ele, "o indivíduo enquanto encarnação do id, do ego e superego, se tornou obsoleto na realidade social" 130 .

Marcuse retoma o pensamento de Sigmund Freud, lembrando que segundo o pai da psicanálise, o indivíduo se constituiria e se desenvolveria no conflito entre ele e a sociedade, conflito esse experimentado e decidido em primeiro lugar e acima de tudo no

\footnotetext{
${ }^{128}$ ADORNO, Theodor. Dialética negativa. Rio de Janeiro: Zahar, 2009 [1966], p. 25.

129 ADORNO, Theodor \& HORKHEIMER, Max. Dialética do esclarecimento. Rio de Janeiro: Jorge Zahar. $2^{\mathrm{a}}$ edição, 2006 [1947], p.10.

130 MARCUSE, Herbert. A obsolescência da psicanálise. Em: Cultura e Sociedade. Vol. 2. Rio de Janeiro: Paz e Terra, 1998 [1965], p. 91.
} 
confronto com o pai, que imporia a subordinação do princípio do prazer ao princípio de realidade. A socialização do indivíduo ocorreria primordialmente no seio da família; seu ego se formaria na esfera familiar, na dimensão privada, portanto ${ }^{131}$. Com as mudanças sociais destacadas por Adorno e Horkheimer, e novamente enfatizadas por Marcuse, essa situação se tornou anacrônica; ela deixou de existir com as transformações que tiveram lugar no entreguerras, entre elas:

[...] passagem da concorrência livre à concorrência organizada, concentração do poder nas mãos de uma administração técnica, cultural e política onipresente, produção e consumo de massa que se expandem automaticamente, sujeição de dimensões outrora privadas e anti-sociais da existência ao adestramento, manipulação e controle metódicos $[\ldots]^{132}$.

Como reflexo da monopolização da economia, a empresa privada e familiar decai, e esta decadência leva ao declínio do papel do pai como agente da socialização psíquica. O filho goza de cada vez mais independência em relação à figura paterna, passando a sociedade a dirigir de modo direto a formação do ego "através da mass media, dos agrupamentos escolares e esportivos, dos bandos de jovens etc." ${ }^{\prime 133}$. As disposições e os comportamentos socialmente necessários para a reprodução social não são mais interiorizados a partir da luta com o pai, mas são precoce e externamente exigidos e suscitados nos indivíduos pela própria instância social (que coletiviza o ideal do ego) cada vez mais racionalizada e, por isso, administrativa:

[...] o ideal do ego (Ichideal) é muito mais levado a agir diretamente e de "fora" sobre o ego, antes ainda que este se tenha constituído de fato como sujeito pessoal e (relativamente) autônomo da mediação entre o próprio eu (Selbst) e os outros. ${ }^{134}$

As palavras de Marcuse sobre as transformações sociais que culminaram no mundo administrado do capitalismo tardio e seus respectivos desdobramentos na formação subjetiva apontam para o mesmo triste, preocupante e alarmante diagnóstico de Adorno e Horkheimer, a saber, o da expropriação psicológica do sujeito no

\footnotetext{
131 MARCUSE, Herbert. A obsolescência da psicanálise. Em: Cultura e Sociedade. Vol. 2. Rio de Janeiro: Paz e Terra, 1998 [1965], p. 93

132 Ibidem, p. 94.

133 Ibidem, p. 94.

${ }^{134}$ Ibidem, p. 94, destaques originais do autor.
} 
capitalismo tardio, o de sua regressão a estágios primitivos do desenvolvimento humano, o da sua reificação:

\begin{abstract}
Essas transformações reduzem o "espaço vital" e a autonomia do ego e preparam o terreno para o surgimento das massas. A mediação entre o eu (Selbst) e o outro dá lugar a uma identificação imediata. Na estrutura da sociedade, o indivíduo torna-se um objeto administrado, consciente, e inconsciente, e obtém liberdade e satisfação em seu papel como um tal objeto; na estrutura psíquica o ego se contrai de tal maneira que já não parece capaz de se manter como um eu distinto do id e do superego. A dinâmica pluridimensional, em virtude da qual o indivíduo alcançava e mantinha seu equilíbrio entre a autonomia e a heteronomia, a liberdade e a repressão, o prazer e a dor, deu lugar a uma dinâmica unidimensional, a uma identificação estática do indivíduo com seus semelhantes e com o princípio de realidade administrado ${ }^{135}$.
\end{abstract}

Tanto o conhecimento, quanto a formação subjetiva devem, portanto, ser compreendidos por meio do fenômeno da reificação, efeito, por sua vez, do progresso histórico da sociedade e da racionalidade administrativa que lhe empresta sua força motriz. Daí a tese central da Dialética do Esclarecimento, de que "a naturalização dos homens hoje não é dissociável do progresso social"136, enunciada no exato momento em que, ainda durante o esforço de guerra, a cibernética dava seus primeiros passos em um projeto de estudo da mente que, desdobrado no desenvolvimento do campo das ciências cognitivas, três décadas depois teria entre seus rebentos as neurociências contemporâneas e a concepção de homem que lhes caracteriza.

O termo naturalização foi usado por Adorno e Horkheimer como sinônimo de reificação, coisificação, objetificação do homem, como alusão ao desenvolvimento de uma segunda natureza, e não no sentido biologicista de redução da subjetividade à dimensão biológica. Não obstante, tendo em vista os desdobramentos das neurociências, bem como minha hipótese, o termo naturalização pode, sem prejuízo, ser compreendido também como redução do sujeito ao seu substrato natural, cerebralização, um modo particular de reificação.

Quando falo em reificação estou me referindo ao embrutecimento do sujeito, à redução do homem à condição de mera coisa. No que concerne à esfera do

${ }^{135}$ MARCUSE, Herbert. A obsolescência da psicanálise. Em: Cultura e Sociedade. Vol. 2. Rio de Janeiro: Paz e Terra, 1998 [1965], p. 94-95.

136 ADORNO, Theodor \& HORKHEIMER, Max. Dialética do esclarecimento. Rio de Janeiro: Jorge Zahar. $2^{\mathrm{a}}$ edição, 2006 [1947], p. 14. 
conhecimento, o conceito se refere ao esquecimento daquilo que não se deixa apreender pela unidade e que, ao ser submetido a tal apreensão, coisifica-se, naturaliza-se, perde seu movimento e sua história pessoal, uma vez que "toda reificação é um esquecimento", sendo a "perda da lembrança" a "condição transcendental da ciência"137. No caso das neurociências, a naturalização se dá pela via biológica mesmo.

Como bem advertiu o neurobiólogo francês Gérard Percheron, "os problemas e o discurso respeitantes ao cérebro ultrapassam os simples jogos científicos" "138. A atividade científica está intimamente vinculada a um modo de vida determinado, datado e baseado em uma racionalidade própria que fundamenta igualmente o pensamento ordinário e o pensamento científico. A ciência é a face institucionalizada do esclarecimento, da racionalidade subjetiva e instrumental. A atividade científica corresponde, sob a divisão do trabalho, a uma forma particular da maneira como a sociedade se confronta com a natureza tendo em vista a sua reprodução ${ }^{139}$. Nesse aspecto ela não difere em nada das outras atividades particulares.

A elaboração de conceitos e teorias, portanto, não é um procedimento lógicomatemático isento de qualquer vinculação social e histórica. A ponderação do cientista sobre a conexão entre teoria e fatos (mesmo em se tratando de lógica ou matemática) é a mesma que pertence a todos os indivíduos $\operatorname{cognoscitivos}^{140}$, uma vez que é perpassada pela mesma racionalidade que, em última instância, baseia-se no princípio da dominação da natureza, tanto a externa quanto a humana, para fins de adaptação e reprodução social.

Há, logo, um enquadramento social das condições em que o conhecimento é produzido, pois a sociedade medeia tanto a formação do sujeito conhecedor quanto a construção do objeto. Os fatos fornecidos pelos sentidos "são pré-formatados de modo duplo: pelo caráter histórico do objeto percebido" - no caso das neurociências, o próprio homem -, “e pelo caráter histórico do órgão perceptivo. Nem um nem outro são

137 ADORNO, Theodor \& HORKHEIMER, Max. Dialética do esclarecimento. Rio de Janeiro: Jorge Zahar. $2^{\text {a }}$ edição, 2006 [1947], p. 190.

${ }^{138}$ PERCHERON, Gerard. Neuromitologias: cérebro, indivíduo, espécie e sociedade. Em: VEYNE, Paul et al. Indivíduo e Poder. Lisboa: Edições 70, 1987, p. 139.

${ }^{139}$ HORKHEIMER, Max. Teoria tradicional e Teoria crítica. Em: Coleção Os Pensadores, v.48. São Paulo: Abril Cultural, 1975 [1937], p. 131.

${ }^{140}$ Ibidem, p. 133. 
meramente naturais [como pretende a ciência do cérebro e, no fundo, toda a ciência natural], mas enformados pela atividade humana"141.

A maneira pela qual as partes são separadas ou reunidas na observação registradora, o modo pelo qual algumas passam despercebidas e outras são destacadas, é igualmente resultado do moderno modo de produção [...] Nas etapas mais elevadas da civilização a práxis humana consciente determina inconscientemente não apenas o lado subjetivo da percepção [a reificação na esfera teórica], mas em maior medida também o objeto [a reificação do próprio homem]. ${ }^{142}$

Então, "a expulsão do pensamento da lógica ratifica na sala de aula a coisificação do homem na fábrica e no escritório" ${ }^{143}$, isto é, a reificação do homem em sua vida efetiva condiciona a do conhecimento, que, ao mesmo tempo, ratifica - ou, o que é pior, aprofunda - a primeira.

A racionalização, a reificação, por fim, o declínio do indivíduo suscitam o estudo objetivo da vida mental e ancoram uma concepção coisificada e formal de homem. É justamente isso que uma breve passada de olhos sobre o desenvolvimento da cibernética, sua contribuição para o desenvolvimento das ciências cognitivas e, por fim, a ascensão das neurociências no interior desse campo multidisciplinar de estudos da mente revela: como ao mesmo tempo em que condições de vida reificadas conduziam o indivíduo a uma experiência cada vez mais empobrecedora do ponto de vista do seu desenvolvimento psíquico, também condicionaram, no plano científico, um olhar pobre e reificado da subjetividade.

${ }^{141}$ HORKHEIMER, Max. Teoria tradicional e Teoria crítica. Em: Coleção Os Pensadores, v.48. São Paulo: Abril Cultural, 1975 [1937], p. 133.

${ }^{142}$ Ibidem, p. 134.

143 ADORNO, Theodor \& HORKHEIMER, Max. Dialética do esclarecimento. Rio de Janeiro: Jorge Zahar. $2^{\mathrm{a}}$ edição, 2006 [1947], p. 37. 


\section{0 estudo objetivo da mente como correspondente cognitivo do processo histórico de expropriação psicológica do sujeito: da cibernética e das ciências cognitivas às neurociências}

A subjetividade tratada objetivamente na vida social desdobra-se em uma subjetividade tratada objetivamente na esfera do conhecimento. O sujeito coisificado na vida imediata condiciona e alimenta a reificação do sujeito na teoria. Essa maneira de compreender a "coincidência" entre o esvaziamento subjetivo real e o avanço de uma concepção "científica" igualmente vazia de homem torna-se bem clara se avaliarmos, mesmo que de modo pouco esmiuçado, o passado recente das neurociências contemporâneas.

Na década de 1940, ao mesmo tempo em que Theodor Adorno e Max Horkheimer, intelectuais alemães emigrados, somavam esforços na perspectiva de lançar alguma luz sobre o desenrolar histórico aterrorizante que testemunhavam e sobre a liquidação acachapante da subjetividade nele flagrante, também nos Estados Unidos inúmeros cientistas (depois batizados de ciberneticistas), de diversas áreas, reuniam-se para uma série de palestras e discussões, animados pelo anseio de alavancar e consolidar uma nova ciência da mente. É desse esforço multidisciplinar que, posteriormente, surge o campo das chamadas ciências cognitivas (entre elas as neurociências). No limite, pode-se considerar que os dois esforços teóricos - o frankfurtiano e o cognitivista/naturalista - deliberadamente ou não, observaram e procuraram dar conta teoricamente do mesmo indivíduo, do mesmo homem, o que torna interessante uma análise crítica do segundo a partir das considerações do primeiro.

A intenção neste texto não é reconstituir a história da cibernética e das ciências cognitivas, embora se sirva de obras que o fizeram. Aqui, o que interessa é destacar algumas preocupações e, sobretudo, alguns anseios comuns a ambos os movimentos científicos - os quais também são visíveis na atual neurociência - o que foi possível fazer me detendo apenas em suas respectivas linhas mestras, em suas motivações mais notáveis. 
Em meados da metade do século XX, intensificou-se a intenção de estudar objetivamente a vida mental, isto é, por meio de métodos e técnicas científicas destituídas de todos os aspectos subjetivos que sempre rondaram a questão. Nesse processo de objetivação do estudo da mente, em um primeiro momento o movimento cibernético e o recém-surgido campo das ciências cognitivas apareceram como protagonistas, papel desempenhado agora pelas neurociências. Como será visto, as neurociências, integrantes do campo das ciências cognitivas, guardando relações íntimas com esse campo, hoje ameaçam engoli-lo.

Como estritamente entrelaçados a essas empreitadas científicas estão o homem e o modo de subjetivação característico da sociedade capitalista tardia, isto é, como em última instância as ideias de homem mobilizadas, consciente ou inconscientemente, pela cibernética, pelas ciências cognitivas e pelas neurociências relacionam-se com o sujeito em sua vida efetiva, repassarei brevemente o desenvolvimento destas teorias de modo a tornar mais ou menos compreensível suas respectivas maneiras de encarar o sujeito e, sobretudo, indicar algo que, embora manifestando-se de distintas maneiras em cada uma dessas áreas, é característico de todas elas, principalmente da atual neurociência e da respectiva cerebralização do sujeito que leva à cabo - refiro-me à condição em que o sujeito aparece como mera coisa, como um simples objeto entre outros, o fenômeno da reificação, o qual se manifesta na crise atual do sujeito, cuja concepção neurocientífica é sintomática.

A relação entre a cibernética e as ciências cognitivas não é fácil de ser compreendida - nem é esse o propósito aqui almejado. Essa dificuldade é visível na literatura: a história das ciências cognitivas editada pelo psicólogo cognitivo Howard Gardner ${ }^{144}$ menciona timidamente o esforço cibernético, assim como a do neurocientista Francisco Varela ${ }^{145}$ e a do filósofo da mente João de Fernandes Teixeira ${ }^{146}$. Quem se detém sobre a questão de forma deliberada é o filósofo Jean-Pierre Dupuy. Sua tese é assertiva: “o que hoje chamamos de 'ciências cognitivas' tem sua origem no movimento

144 Cf. GARDNER, Howard. A Nova Ciência da Mente. São Paulo: Edusp, 1996.

145 Cf. VARELA, Francisco. Conhecer: as ciências cognitivas, tendências e perspectivas. Lisboa: Instituto Piaget, s/d.

146 TEIXEIRA, João de Fernandes. Mentes e Máquinas: uma introdução às ciências cognitivas. Porto Alegre, Artes Médicas, 1998. 
cibernético"147, não obstante a cibernética seja tratada como uma "parenta mal amada", cujo parentesco muitas vezes sequer é reconhecido pelas ciências cognitivas ${ }^{148}$.

Jean-Pierre Dupuy estabelece o ano de 1943 como o de origem da cibernética. A data se deve à publicação independente de dois artigos fundadores. O primeiro escrito por Arturo Rosenblueth, Norbert Wiener e Julian Bigelow — se intitula Behavior, Purpose and Teleology; o segundo, A Logical Calculus of the Ideas Immanent in Nervous Activity, foi escrito pelo neuropsiquiatra Warren McCulloch e pelo matemático Walter Pitts.

Wiener, talvez o nome mais diretamente associado à cibernética, era um matemático aplicado que, ao lado de Bigelow, em pleno esforço de guerra, trabalhou com os problemas teóricos da defesa antiaérea estadunidense ${ }^{149}$. Mais tarde, Bigelow foi recomendado por Wiener a John Von Neuman e se tornou o engenheiro chefe da construção do grande computador JONIAC, essencial no posterior desenvolvimento da bomba $\mathrm{H}^{3}$ (de poder de destruição muito maior do que qualquer bomba atômica).

Dado o interesse mútuo pela Psicologia, Wiener e Rosenblueth discutiram com Bigelow a respeito da possibilidade de aproximação da conceptualização sobre a defesa antiaérea - pensada em termos de inputs, outputs e feedback (retroalimentação) — dos processos envolvidos no movimento voluntário de um sujeito ${ }^{150}$. Essa preocupação levou ao artigo supracitado.

A cibernética, tal como se vê antecipada no artigo de 1943, avalia Dupuy, trata inegavelmente seus objetos de estudo como dispositivos que transformam mensagens de entrada (inputs) em mensagens de saída (outputs), impedindo-a de recair no esquema behaviorista a noção de feedback (retroalimentação, influência do output sobre o input $)^{151}$.

A vontade dos cibernéticos de permanecer no exterior dos objetos, ignorando seu conteúdo particular, fica clara em uma discussão travada na Oitava Conferência

\footnotetext{
${ }^{147}$ DUPUY, Jean-Pierre. Nas origens das ciências cognitivas. São Paulo: Ed. Unesp, 1996, p. 44.

148 Ibidem, p.45.

${ }^{149}$ A ideia era criar um sistema que previsse a trajetória dos misseis inimigos, possibilitando que fossem abatidos antes de atingirem o alvo.

${ }^{150}$ DUPUY, Jean-Pierre. Nas origens das ciências cognitivas. São Paulo: Ed. Unesp, 1996, p. 46.

${ }^{151}$ Ibidem, 1996, p. 47.
} 
Macy $^{152}$, em 1951. Herbert Birch, ao discutir casos de comunicação entre insetos, tomou o seguinte exemplo a fim de defender sua tese de que só observamos verdadeiras comunicações a partir dos mamíferos superiores (reproduzo com minhas palavras): a vieira é um dos pratos preferidos da estrela-do-mar; a última, quando próxima da primeira, sempre causa nela uma reação de fuga. Nessas condições, pode-se dizer que a primeira se comunicou com a segunda? Se sim, é válido continuar dizendo o mesmo, caso se troque a estrela do mar por uma porção dela cozida, o que produziria o mesmo efeito? Birch termina sua exposição examinando o que distingue as "verdadeiras" comunicações, que segundo ele são vistas nos mamíferos superiores e culminam no homem: "elas implicam antecipação, intencionalidade, simbolização e requerem capacidades de aprender, de perceber, de tecer relações sociais"153. Segundo Dupuy, Rosenblueth explode, dizendo que essas distinções carecem de sentido já que remetem ao que se passa na mente dos sujeitos, não podendo ser objeto de qualquer medição ${ }^{154}$, como se, não podendo ser medidas, não tivessem pertinência para o estudo da comunicação e do comportamento dos homens e/ou dos animais.

Ainda que os cibernéticos não se contentassem com as respostas behavioristas (assim como os cognitivistas, o que veremos a seguir):

\begin{abstract}
A ciência da mente que a cibernética [pretendia] construir [era], na terminologia de hoje, decididamente "eliminacionista" [como a behaviorista]. Os "estados mentais" que a psicologia comum ou ingênua invoca para dar conta dos comportamentos, como as crenças, os desejos, a vontade, as intenções, etc., [deveriam] ser banidos da explicação científica. [...] A distinção tão fundamental na história da psicologia, entre comportamento voluntário e comportamento reflexo [perdia] com eles todo o sentido, bem como a diferença entre consciência e inconsciente. ${ }^{155}$
\end{abstract}

Aquilo que é essencialmente subjetivo, longe de ser algo relevante ao qual deve ser dada toda a atenção, torna-se algo que deve ser eliminado da análise sob o risco de torná-la não-científica. O homem foi assim assimilado a uma máquina. Porém, tal

\footnotetext{
${ }^{152}$ As conferências Macy foram as ocasiões em que os cibernéticos se encontraram. A denominação se deve ao patrocínio da Fundação Josiah Macy Jr. No total foram dez conferências, todas marcadas pela interdisciplinaridade, realizadas entre 1946 e 1953.

${ }^{153}$ DUPUY, Jean-Pierre. Nas origens das ciências cognitivas. São Paulo: Ed. Unesp, 1996, p. 50

${ }^{154}$ Ibidem, p. 51

${ }^{155}$ Ibidem, p. 51.
} 
assimilação não foi entendida como uma redução, pois a máquina seria um modelo nos dois sentidos da palavra ${ }^{156}$.

O segundo artigo, por sua vez, tem como ambição fundar uma neurologia da mente. Radicalizando a postura de Wiener, Bigelow e Rosenblueth, que negam a realidade do mental e compreendem sua evocação como mera comodidade linguística, McCulloch e Pitts se perguntaram pelos mecanismos lógicos e materiais que encarnam a mente. Os comportamentos dos sujeitos passaram a ser pensados em termos dos comportamentos de unidades lógicas menores e impenetráveis, de operadores que transformam inputs em outputs - os neurônios. Assim, o cérebro é entendido não apenas como tendo funcionamento análogo ao de uma máquina lógica, mas como ele próprio sendo uma máquina a funcionar no interior de uma máquina maior, o homem. E a mente? A mente é uma função do cérebro. Ambos são um só, uma mesma máquina.

Nos anos seguintes à efervescência intelectual provocada pelos encontros dos ciberneticistas, ocorridos sob os auspícios da Fundação Josiah Macy Jr., entre 1946 e 1953, a preocupação com o suporte biológico da mente não foi levada adiante. Com o advento das ciências cognitivas (não apenas em meio ao clima criado pela cibernética, mas também devido a ele), foi o paradigma cognitivista que prevaleceu (sem dúvidas um paradigma dualista da mente, defensor de um nível simbólico dotado de autonomia ante o nível físico-biológico), deixando a biologia - logo, o cérebro - em segundo plano, quadro que se inverteu posteriormente, na década de 1970. Repassemos o desenvolvimento do cognitivismo como resposta ao problema da objetividade no estudo da subjetividade.

Desde o final dos anos 1930 a Psicologia encontrava-se em crise — isso, ao menos, no contexto estadunidense. Não apenas psicólogos, como muitos daqueles interessados nos mais variados aspectos da vida mental (entre eles biólogos, neurofisiologistas, matemáticos, antropólogos etc.) colocaram-se como exigência um paradigma, um ponto de partida consensual sobre o qual fosse possível fundar as bases de uma verdadeira ciência da mente, exigência essa não atendida à altura pelas duas

\footnotetext{
${ }^{156}$ DUPUY, Jean-Pierre. Nas origens das ciências cognitivas. São Paulo: Ed. Unesp, 1996, p. 52.
} 
grandes escolas psicológicas do século XX, até então: a Psicanálise e o Behaviorismo $^{157}$.

Se a Psicanálise raramente foi levada a sério nos Estados Unidos, o Behaviorismo atendia a muitas necessidades da comunidade científica, como a crítica do valor aparente de evidências subjetivas sem medida de controle e possibilidade de refutação, e o descontentamento com o uso de conceitos genéricos e vagos como o de desejo, condição que lhe rendeu uma difusão arrebatadora durante as décadas de 1920, 1930 e $1940^{158}$. No entanto, o esquema rígido de tipo estímulo-resposta dos behavioristas, do "cérebro caixa-preta", não dava conta de explicar uma série considerável de fenômenos complexos, como a solução de problemas, o pensamento, a imaginação e a linguagem ${ }^{159}$.

Esses psicólogos, biólogos, neurofisiologistas, matemáticos, linguistas e afins compartilhavam "a intuição de que a resposta behaviorista a questões da mente humana não era na verdade nenhuma resposta" ${ }^{\# 160} \mathrm{e}$, dado suas mais variadas formações acadêmicas, compartilhavam também um conhecimento diversificado e ao mesmo tempo aprofundado dos novos achados técnico-científicos (como a teoria computacional, o modelo neuronal, a teoria da informação, o conhecimento das alterações cognitivas causadas por lesões cerebrais etc.) que os levaram, reunidos em inúmeros simpósios, congressos e conferências ao longo das décadas de 1940 e 1950, a fundar um novo campo de estudo da mente, posteriormente batizado pelo psicólogo George A. Miller de ciências cognitivas ${ }^{161}$.

O artigo do neuropsicólogo Karl Lashley, The Serial Order of Behavior, apresentado em 1948 no famoso Simpósio Hixon, cristalizava uma consciência crescente por parte de diversos cientistas de que a adesão aos cânones behavioristas estava tornando impossível um estudo científico da mente ${ }^{162}$. Debruçando-se sobre a linguagem, Lashley foi taxativo ao dizer que sua compreensão exige muito mais do que

\footnotetext{
157 TEIXEIRA, João de Fernandes. Mentes e Máquinas: uma introdução às ciências cognitivas. Porto Alegre, Artes Médicas, 1998, p. 10.

${ }^{158}$ GARDNER, Howard. A Nova Ciência da Mente. São Paulo: Edusp, 1996, p. 27.

${ }^{159}$ Cf. GARDNER, Howard. A Nova Ciência da Mente. São Paulo: Edusp, 1996, p 27; TEIXEIRA, João de Fernandes. Mentes e Máquinas: uma introdução às ciências cognitivas. Porto Alegre, Artes Médicas, 1998, p. 11.

${ }^{160}$ GARDNER, Howard. A Nova Ciência da Mente. São Paulo: Edusp, 1996, p. 30.

161 Ibidem, p. 31-45.

162 Ibidem, p. 27.
} 
a consideração de estímulos e respostas, isto é, que fenômenos complexos exigem um nível de planejamento, processamento de informação ou estados mentais entre um input e um output. Contudo, voltar a falar sobre representações e estados mentais antes de ser uma solução foi um problema, pois como estudar esses estados internos ou essas representações sem retornar ao introspeccionismo ou à psicologia de poltrona? Como não jogar por água abaixo o ideal de objetivação do estudo da subjetividade? A resposta dada foi: por meio da lógica e da matemática, isto é, por meio da analogia entre a mente e computador ${ }^{163}$.

A preocupação com o funcionamento da mente se vinculou intimamente com a teoria computacional e com a criação dos primeiros computadores pela Inteligência Artificial. O espírito passou a ser entendido como uma espécie de lógica "assimilável, portanto ao comportamento de um computador"164. A hipótese cognitivista é, pois, a de que a inteligência se aproxima "de tal forma daquilo que é um computador que a cognição pode ser definida pela computação de representações simbólicas do mundo que cerca o sujeito cognoscitivo"165. Para além do nível da física e da neurobiologia, o cognitivismo postula um nível simbólico e semântico distinto e irredutível. Aqui, a preocupação é mais com o nível representacional do tratamento de informações, isto é, com o software em detrimento do hardware.

Porém, depois de vinte anos de dominância no campo das ciências cognitivas, a partir da década de 1970 a hipótese cognitivista começou a perder terreno sob a alegação de que havia se distanciado das raízes biológicas da cognição. Com a hipótese conexionista, a cognição passa a ser entendida como "a emergência de estados globais numa rede de componentes simples", os quais nada mais são do que os neurônios ${ }^{166}$. Assim:

[...] o cérebro viria a ser, novamente, a fonte de metáforas e de ideias para outros domínios das ciências cognitivas. Aqui o ponto de partida não é uma descrição simbólica abstrata, mas todo um conjunto de constituintes simples

\footnotetext{
163 TEIXEIRA, João de Fernandes. Mentes e Máquinas: uma introdução às ciências cognitivas. Porto Alegre, Artes Médicas, 1998, p. 11.

${ }^{164}$ VARELA, Francisco. Conhecer: as ciências cognitivas, tendências e perspectivas. Lisboa: Instituto Piaget, s/d, p. 30.

${ }^{165}$ Ibidem, p. 29

${ }^{166}$ Ibidem, p. 62.
} 
e não inteligentes que, como os neurônios, exprimem propriedades globais interessantes quando estão ligados entre si ${ }^{167}$.

Como interpreta Varela, a crítica conexionista ao cognitivismo inverte a lógica do perito e da criança. Enquanto os cognitivistas visavam questões mais genéricas e abstratas, tais como a tradução de línguas naturais e a resolução de grandes problemas, esqueceu-se de que a criança era mais genial que o perito, "que a inteligência mais profunda e mais fundamental era a do bebê", pois aprendia tudo do nada, ou melhor, tudo a partir de um suporte biológico ainda desorganizado, o qual havia sido negligenciado até então ${ }^{168}$.

Com todos os avanços das ciências cognitivas, com o desenvolvimento da biologia molecular, da farmacologia e da engenharia genética e, sobretudo, com o aperfeiçoamento dos métodos de imageamento pela física, abriu-se "o caminho para novas investigações sobre a relação entre os estados mentais e a atividade física do cérebro" ${ }^{169}$. Partilhando desta preocupação comum, tais disciplinas criaram um nuovo cimento sobre o qual se fundou um novo campo de pesquisas, o das neurociências, cujo nascimento simbólico, segundo o neurocientista francês Jean-Pierre Changeux ${ }^{170}$, data de 1971, nos Estados Unidos, com a primeira reunião da Society for Neuroscience ${ }^{171}$.

Em síntese, a moderna neurociência integra o campo interdisciplinar das "ciências cognitivas" (psicologia cognitiva, inteligência artificial, linguística, antropologia, neurociências etc.), que emergiu em meados da década de 1940, a partir da cibernética e de seu esforço em contrapor-se ao Behaviorismo e à Psicanálise. Essa contraposição originou-se de certas exigências de formalização e cientificidade, isto é, de objetivação do estudo da subjetividade, que em um primeiro momento resultou na analogia entre a mente e o computador, entre o pensamento e o cálculo lógicocomputacional de símbolos abstratos. A ascensão das neurociências e de sua visão de

${ }^{167}$ VARELA, Francisco. Conhecer: as ciências cognitivas, tendências e perspectivas. Lisboa: Instituto Piaget, s/d, p.46.

${ }^{168}$ Ibidem, p. 47.

${ }^{169}$ CHANGEUX, Jean-Pierre. A verdade, o belo e o bem: uma nova abordagem neuronal. Civilização Brasileira: Rio de Janeiro, 2013, p. 19.

${ }^{170}$ Neurocientista francês, professor do Collège de France há mais de 30 anos, diretor da Unidade de Neurobiologia Molecular do Institut Pasteur. Sua "militância" é bastante interessante, pois em diversos momentos busca "dialogar" com teorias vindas das ciências humanas (filosofia, sociologia, história, antropologia, etc.), porém sempre na chave redutora do naturalismo.

${ }^{171}$ CHANGEUX, Jean-Pierre. A verdade, o belo e o bem: uma nova abordagem neuronal. Civilização Brasileira: Rio de Janeiro, 2013, p. 19. 
homem sobre as outras disciplinas cognitivas ocorreu a partir de uma inflexão do modelo computacional da mente, já na década de 1970. Não se tratou de negar o estatuto lógico do funcionamento mental, nem sua definição como processo de tratamento informacional - a qual permanece intacta até hoje ${ }^{172}$-, mas de apontar para o fato de que, até então, os cognitivistas haviam se esquecido de algo indiscutivelmente mais importante e determinante do que esse estatuto: essas operações não são simplesmente mentais, mas cerebrais; são resultados da interação entre células vivas e complexas, os neurônios.

Grosso modo, a mente e os conceitos da psicologia que se referem a ela de forma dualista (separando cérebro e mente como realidades autônomas) não passam, então, de ilusões a serem desmascaradas pelo avanço das pesquisas com o cérebro.

Evitando qualquer discussão minuciosa sobre os diversos debates no interior do movimento cibernético, do campo das ciências cognitivas e das neurociências, algo que não seria capaz de fazê-lo, gostaria que ficasse frisado o que interessa nisso tudo: a desconfiança do particular em benefício do geral; o tratamento exacerbadamente objetivo, formal e por isso reificado da subjetividade, tendência teórica que se acentua com a crescente importância cultural do cérebro nas discussões sobre tudo o que diz respeito ao homem, em detrimento da consideração de qualquer instância ou conceito que remeta a um debate afastado da concretude da carne, tal como o conceito abrangente de mente como algo destacado da biologia, detentor de alguma autonomia ainda que no máximo relativa - o que ainda ocorria, de certa forma, sob o paradigma cognitivista.

Com efeito, as dimensões psicológica e sociológica da existência humana têm sido cada vez mais negligenciadas, para não dizer obliteradas. O movimento cognitivo que vai da cibernética, passando pelo advento das ciências cognitivas e culmina na atual ascensão das neurociências, cuja concepção científica de homem e sua divulgação na esfera da cultura foram apresentadas no capítulo I, deve ter dado margem suficiente para que esse reducionismo cego fosse enxergado da maneira como tem se desenvolvido desde meados do século XX e como tem se manifestado atualmente

${ }^{172}$ VARELA, Francisco. Conhecer: as ciências cognitivas, tendências e perspectivas. Lisboa: Instituto Piaget, s/d, p. 40. 


\section{A concepção neurocientífica de homem e seu sucesso como efeitos da reificação da sociedade e do sujeito: crítica do conhecimento é crítica da sociedade e vice-versa}

Os problemas e o discurso respeitantes ao cérebro ultrapassam os simples jogos científicos.

Gérard Percheron, Neuromitologias: cérebro, indivíduo, espécie e sociedade.

[...] somente a tomada de consciência do social proporciona ao conhecimento a objetividade que ele perde por descuido enquanto obedece às forças sociais que o governam, sem refletir sobre elas. Crítica da sociedade é crítica do conhecimento, e vice-versa.

Theodor Adorno, Sobre sujeito e objeto.

A tão almejada objetividade pretendida por esses cientistas que se preocuparam com a mente humana nos últimos sessenta anos, em outras palavras, o estudo objetivo da subjetividade é alcançado no caso específico das neurociências por meio do materialismo biológico, por assim dizer, por meio do estudo detido da carne, da massa cerebral.

Tendo em vista a ascensão das neurociências tanto na dimensão do conhecimento quando na da cultura em geral, outra concepção de sujeito não apenas emergiu como se tornou preponderante, figura esta que por um lado enfatiza o corpo e as leis de seu funcionamento e, por outro, ignora ou mesmo oblitera aspectos relacionais da subjetividade, apartando do sujeito seus desejos e fantasias, suas particularidades, sua história pessoal, ignorando os poderes que agem sobre ele e sobre os quais ele age ou ao menos tenta agir.

A concepção neurocientífica de homem não é, no entanto, toda ela falsa. Além de sua larga parcela ideológica, ela reflete algo verdadeiro. De fato a subjetividade hoje se encontra em maus bocados, regredida, esvaziada. A falsidade da visão cerebral reside no fato de que isso se deve a um processo histórico e social, não se tratando de algo 
naturalmente ontológico, essencialmente imutável. Eis aqui sua parcela ideológica, sua dimensão irrefletida que termina por funcionar socialmente como instrumento de perpetuação do status quo, como justificação da realidade do infortúnio individual, já que tamanha naturalização conduz, em última instância, à identificação e ao conformismo estrito em relação à realidade, tema de que tratarei no capítulo III.

Em uma densa e bela passagem da Dialética do Esclarecimento, Adorno e Horkheimer disseram que a "impotência dos trabalhadores não é mero pretexto dos dominantes, mas a consequência lógica da sociedade industrial, na qual o fado antigo acabou por se transformar no esforço de a ele escapar" ${ }^{173}$. Do mesmo modo, a visão empobrecida de homem não é mero pretexto das neurociências para se legitimarem e potencializarem os efeitos de suas pesquisas e respectivas aplicações práticas em favor da dominação social, tudo racionalmente planejado em um conluio macabro entre laboratórios, governos e elites econômicas; sua concepção de homem é antes consequência impensada dessa impotência de que nos falam os frankfurtianos, é consequência quase lógica da pobreza subjetiva do próprio homem tal como este nos deixa lhe perceber em seu dia-a-dia: com suas qualidades transformadas em meras funções pela moderna divisão do trabalho (portanto reificadas e condenadas à atrofia), agindo por reflexos, identificando-se automaticamente aos desígnios coletivos, enfim, como um sujeito com pouca ou sem qualquer subjetividade, reificado, mera "célula de reação funcional”. Se lembrarmos de Horkheimer na epígrafe do primeiro item deste capítulo, “o indivíduo não é nada senão uma espécie biológica enquanto seja apenas a encarnação de um ego definido pela coordenação de suas funções a serviço da autopreservação" ${ }^{174}$, o que de fato tem ocorrido, veremos com clareza que o sujeito cerebral de que falam as neurociências - um sujeito sem subjetividade, esvaziado, empobrecido -não surgiu do vácuo.

Em vista disso, torna-se razoável afirmar que há uma conexão estreita e direta entre o atrofiamento da subjetividade devido ao crescente caráter administrativo da sociedade e o desenvolvimento acentuado da figura cerebral na esfera do conhecimento; o recente e atual fenômeno da cerebralização pode ser entendido como um episódio

\footnotetext{
173 ADORNO, Theodor \& HORKHEIMER, Max. Dialética do esclarecimento. Rio de Janeiro: Jorge Zahar. $2^{\mathrm{a}}$ edição, 2006 [1947], p. 42.

174 HORKHEIMER, Max. Eclipse da Razão. São Paulo: Unesp, 2015 [1947], p. 152.
} 
particular do fenômeno da reificação, estando, então, vinculado de modo inextricável ao empobrecimento do sujeito no mundo administrado do capitalismo tardio.

Francis Wolff declarou, a respeito da ideia de homem das neurociências, que ela "é vaga, objetivamente vaga", sendo que "ser vaga é seu traço mais nítido"175.

Essa vagueza é tradução da reificação do sujeito. O esvaziamento teórico operado pela neurociência seria, assim, o correspondente cognitivo do esvaziamento psicológico do sujeito no capitalismo tardio, de seu empobrecimento psíquico ante a racionalização crescente da sociedade, da mesma maneira que o sujeito da psicanálise fora reflexo do sujeito liberal em suas zonas de atrito com a moral repressiva da época.

O movimento de ascensão das neurociências sobre a psicanálise corresponde ao movimento histórico da individualidade que vai da mônada liberal ao sujeito expropriado psicologicamente do capitalismo tardio. Por não haver maiores distinções objetivas entre os indivíduos, tendo em conta a atual totalização da sociedade como instância administrativa que obstrui o desenvolvimento humano e confere um ar de semelhança a todos, é que o sujeito pôde ser naturalizado e tomado por seu cérebro.

Daí adviria, a despeito de suas diversas manifestações passadas ${ }^{176}$, o recente sucesso cultural da concepção cerebral de homem, sucesso que exige a análise de outra dimensão do problema: a da recepção subjetiva dessa concepção. Do ponto de vista da gênese teórico-científica da figura neurocientífica de homem é o que tenho a dizer.

E quanto a sua recepção pelos sujeitos? E quanto a seu sucesso cultural? Por que os indivíduos cada vez mais parecem aceitá-la e mobilizá-la na condução e na compreensão de suas próprias vidas?

Até o presente momento minha atenção esteve voltada para a cerebralização do sujeito na esfera do conhecimento, para o sucesso cultural da concepção neurocientífica de homem, sempre perceptível no plano das representações correntes e onipresente no imaginário social. Entretanto, existe a dimensão subjetiva do problema da cerebralização que aqui só está presente nas entrelinhas e que embora merecedora de toda atenção tendo em conta o escopo deste trabalho, só será desenvolvida de maneira

\footnotetext{
${ }^{175}$ WOLFF, Francis. Nossa humanidade: de Aristóteles às neurociências. São Paulo: Unesp, 2012, p. 115.

176 Cf. Observação Preliminar: a secular história do cérebro, p. 18 desta dissertação.
} 
provisória, como uma questão aberta para questionamentos futuros. Trata-se da cerebralização empreendida pelos próprios sujeitos em suas vidas.

A ascensão do conhecimento neurocientífico na esfera da cultura só é possível porque ele encontra guarida nos sujeitos. De que modo isso ocorre? Por que ocorre? A que necessidade, desejo ou angústia dos homens responde, satisfaz ou aplaca a ideia de que suas ações, seus sentimentos, seus pensamentos, seus dramas pessoais devem-se à configuração e ao funcionamento do seu cérebro, sejam eles considerados patológicos ou saudáveis?

Penso que a explicação dessa ampla e irrefletida aceitação da parte dos indivíduos encontra-se no mesmo diagnóstico que propus como base para compreender a gênese teórica da concepção neurocientífica de homem: a crise da individualidade no mundo administrado.

A hipótese aqui trabalhada é a de que a concepção coisificada de homem das neurociências é reflexo da reificação do homem, da expropriação psicológica do sujeito no capitalismo tardio. No mundo administrado de hoje, a relação entre indivíduo e sociedade é dominada pela instância social, que se tornou uma segunda natureza, mais enrijecida e inalcançável do que a primeira, uma criação que se alienou e voltou-se contra o seu criador, ignorando e obstando o desenvolvimento individual.

Adorno, em Sobre a relação entre a sociologia e a Psicologia, lembra que:

$\mathrm{Na}$ medida em que as ações sociais, através das quais a vida dos seres humanos se reproduz, separam-se deles mesmos, ficam impedidos de compreender a fundo a maquinaria social e são entregues à fórmula de que tudo se resumiria tão somente ao ser humano [...] A intransparência da objetividade alienada empurra os sujeitos de volta a seu eu restrito e os ilude ao lhes colocar seu ser-em-si separado, o sujeito monadológico e sua psicologia, como o essencial.

O culto da psicologia, que se impinge à humanidade e à qual se preparou nos Estados Unidos um insosso meio de alimentação popular, é o complemento da desumanização, a ilusão dos impotentes de que seu destino dependeria de sua própria constituição ${ }^{177}$.

177 ADORNO, Theodor. Sobre a relação entre sociologia e psicologia. Em: Ensaios sobre psicologia social e psicanálise. São Paulo: Unesp, 2015, p. 86 
Se em 1955 disse isso sobre a psicologia, o que diria Adorno sobre as neurociências, sobre sua figura de homem, nos dias de hoje? Isso jamais saberemos. $\mathrm{O}$ que eu digo é que, do mesmo modo que a psicologia (segundo Adorno), as neurociências se alimentam dessa tendência de inflexão rumo ao sujeito, alimentam-se da ideologia do individualismo, como também observou Alain Ehrenberg. Todavia, quando comparada a qualquer psicologismo, a difundida concepção de homem das neurociências representa um grave passo adiante na desumanização. Sua imagem de sujeito, sua compreensão do mental (nada além de sinônimo de cerebral) é mais empobrecida, é mais vazia, desencantada, sem significado, mais objetiva e formal, é ausente de qualquer vestígio de subjetividade. O ditado popular que diz "que não há nada ruim que não possa piorar" se aplica bem ao caso. No entanto, isso dificulta a tentativa de estabelecer qualquer explicação para sua aceitação, afinal, o que levaria os sujeitos a fazê-lo, se a sua inconsistência e limitação são patentes?

Renato Janine Ribeiro argumenta que as pesquisas que vêm naturalizando o ser humano se beneficiam de uma disposição do homem a se considerar coisa, e portanto a resolver seus problemas como se ele fosse um objeto, do que a se reconhecer como sujeito e se responsabilizar por eles ${ }^{178}$. Ainda segundo Janine-Ribeiro, isso significa uma mudança na ideia levantada por Georg Lukács em sua crítica da reificação, pois quando ele e outros pensadores denunciaram a reificação do homem efetuada pelo capitalismo:

[...] esqueceram-se de acrescentar - ou não puderam fazê-lo, presos que estavam ao paradigma da repressão que vem de cima para baixo, não compreendendo aquela que vem de dentro - que, se ela é tão bem sucedida, é porque tornar-se coisa pode ser um forte desejo nosso. E isso, antes de mais nada, porque nos libera de um enorme peso, o de decidir. Devemos introduzir nesse fenômeno, a partícula que designa o que fazemos sobre nós mesmos, o reflexivo: e falar em auto-reificação do ser humano. ${ }^{179}$

Esse "forte desejo nosso" de tornar-se coisa me parece "a saída" encontrada pelos indivíduos para as exigências sociais que, não por acaso, esperam dos homens que estes funcionem justamente como coisas, como objetos. Ainda que se possa argumentar que esse tal desejo tenha manifestações anteriores ao mundo claustrofóbico do

\footnotetext{
${ }^{178}$ RIBEIRO, Renato Janine. Novas fronteiras entre natureza e cultura. Em: ADAUTO, Novaes (org). O Homem- Máquina: a ciência manipula o corpo. São Paulo: Companhia das Letras, 2003, p. 24.

${ }^{179}$ Ibidem, p. 25.
} 
capitalismo tardio, ele deve ser entendido menos como expectativa do sujeito atendida pelo meio social e mais como uma resposta subjetiva à "camisa-de-força de coerções sociais e psíquicas" ${ }^{180}$ que se tornou a vida atual. Discordando, portanto, da posição idealista de Janine-Ribeiro, penso que o desejo de tornar-se coisa é a resposta dos sujeitos às expectativas e pressões sociais objetivas que fatalmente os colocam no lugar de coisas.

Aqui o pensamento de Adorno e Horkheimer surge como aporte valioso. A "auto-reificação", a cerebralização do sujeito por ele mesmo é resultado da reificação do todo, é efeito perverso da experiência cotidiana de homens anulados em face dos poderes econômicos ${ }^{181}$, de homens que em algum lugar de suas consciências reconhecem que são joguetes de relações entre nações e entre mercados internacionais, que são atravessados por infinitos poderes em relação aos quais pouco ou nada podem fazer; em última instância, de homens que perplexa e confusamente percebem em algum grau que não são donos de suas próprias vidas e que as têm ameaçadas ininterruptamente por algo que eles mesmos contribuem a cada segundo para reproduzir (a sociedade).

A relação dos indivíduos com a sociedade é experimentada por eles "através de um extremo de dor física e sofrimento psíquico"182. Manter-se responsável por sua vida psíquica, nessas condições, significa no limite ter que encarar o mundo seja de que forma for, o que exige uma "força" extraordinária do sujeito, demanda uma capacidade de resistência e resiliência que talvez poucos tenham tido a chance de desenvolver, dada a extensão da reificação por todas as dimensões da vida, dados os incontáveis obstáculos que prejudicam o desenvolvimento psíquico de muitos de nós desde a primeira infância.

Horkheimer disse, sobre os indivíduos que conseguem atingir algum nível de compreensão sobre o hiato que caracteriza o que nos é exigido pela civilização e o que nos é dado em troca, que eles podem agregar a seu caráter um entre dois elementos, um deles sendo a resistência:

\footnotetext{
${ }^{180}$ MATOS, Olgária C.F. Ulisses e a razão insuficiente: geometria e melancolia. Em: O iluminismo visionário: Benjamin, leitor de Descartes e Kant. São Paulo: Brasiliense, 1993, p. 160

181 ADORNO, Theodor \& HORKHEIMER, Max. Dialética do esclarecimento. Rio de Janeiro: Jorge Zahar. $2^{\mathrm{a}}$ edição, 2006 [1947], p. 14.

182 ADORNO, Theodor. Sobre a relação entre sociologia e psicologia. Em: Ensaios sobre psicologia social e psicanálise. São Paulo: Unesp, 2015, p. 134.
} 
O outro elemento, a submissão, é aquele a que a maioria é levada a aceitar. Embora a maior parte das pessoas jamais supere o hábito de repreender o mundo por suas dificuldades, aqueles que são excessivamente fracos para posicionarem-se contra a realidade não têm outra opção a não ser a de identificar-se com ela, obliterando-se. Eles nunca se reconciliaram racionalmente com a civilização. Em vez disso, curvam-se a ela, aceitando secretamente a identificação entre a razão e a dominação, entre a civilização e o ideal, não importando o quanto encolham os ombros. ${ }^{183}$

É isso que penso quando me deparo com a aceitação da concepção neurocientífica de homem pelos sujeitos: trata-se de uma forma de identificar-se com a realidade, de diluir-se nela, dada a dificuldade que implica resistir a ela afirmando-se como sujeito.

As reflexões da psicanalista Elisabeth Roudinesco acerca da sociedade contemporânea e da "derrota do sujeito" auxiliam no entendimento desse argumento da identificação. Em Por que a psicanálise?, ao problematizar a epidemia depressiva, disse que "a sociedade democrática moderna quer abolir de seu horizonte a realidade do infortúnio, da morte e da violência" e que por isso, "em nome da globalização e do sucesso econômico", ela tem tentado exorcizar a ideia de conflito social, que deixou de ser a base normativa da subjetividade - no que acompanha (isso quem está dizendo sou eu, e não a autora) os argumentos já discutidos de Alain Ehrenberg, por um lado, e dos frankfurtianos, por outro. Como efeito, a modernidade "passou da era do confronto para a da evitação, e do culto da glória para a revalorização dos covardes", de modo que o "indivíduo tem o direito e, portanto o dever, de não mais manifestar seu sofrimento" 184 . Essa transformação se revela na substituição da concepção psicanalítica de sujeito, centrada no conflito, por outra mais isenta ${ }^{185}$ :

Sabemos que a invenção freudiana de uma nova imagem da psique pressupôs a existência de um sujeito capaz de internalizar as proibições. Imerso no inconsciente e dilacerado por uma consciência pesada, esse sujeito, entregue a suas pulsões pela morte de Deus, está sempre em guerra consigo mesmo. Daí decorre a concepção freudiana da neurose, centrada na discórdia, na angústia, na culpa. Ora, é essa ideia da subjetividade, tão característica do advento das sociedades democráticas, elas próprias baseadas no confronto permanente entre o mesmo e o outro, que tende a se apagar da organização

\footnotetext{
${ }^{183}$ HORKHEIMER, Max. Eclipse da Razão. São Paulo: Unesp, 2015 [1947], p. 127.

${ }_{185}^{184}$ ROUDINESCO, Elisabeth. Por que a psicanálise? Rio de Janeiro: Jorge Zahar, 2000, p. 16, grifo meu.

${ }^{185}$ Ibidem, p. 17
} 
mental contemporânea, em prol da noção psicológica de personalidade depressiva.

Saída da neurastenia, noção abandonada por Freud, e da psicastenia descrita por Janet, a depressão não é uma neurose nem uma psicose nem uma melancolia, mas uma entidade nova, que remete a um "estado" pensado em termos de "fadiga", "déficit" ou "enfraquecimento da personalidade". O crescente sucesso dessa designação deixa bem claro que as sociedades democráticas do fim do século XX deixaram de privilegiar o conflito como núcleo normativo da formação subjetiva. Em outras palavras, a concepção freudiana de um sujeito do inconsciente, consciente de sua liberdade, mas atormentado pelo sexo, pela morte e pela proibição, foi substituída pela concepção mais psicológica de um indivíduo depressivo, que foge de seu inconsciente e está preocupado em retirar de si a essência de todo conflito. ${ }^{186}$

Desse modo, havendo a neurobiologia e a psicofarmacologia, para os indivíduos não se trata mais de "entrar em guerra com o mundo, mas de evitar o litígio, aplicando uma estratégia de normalização"187.

Assim, em uma situação de constante hostilidade e ameaça a sua autonomia como a que se encontra atualmente o sujeito contemporâneo, sem meios elaborados de salvaguardar sua já frágil capacidade de se autotutelar, o recurso do eu para sair "vencedor" das aventuras do mundo contemporâneo é o mesmo de Ulisses: "perder-se para se conservar [...]" ${ }^{188}$. No caso, reduzir-se ao cérebro, desincumbir-se de si mesmo, desresponsabilizar-se por si próprio e por sua relação com o mundo, "tornar-se coisa" em um mar de coisas.

Não que alguém deprimido, por exemplo, deva se responsabilizar por seu estado - no sentido de se compreender como o culpado por ele (culpa e responsabilidade não são sinônimos). Mas que esse alguém, ou melhor, esse $E u$, deva se responsabilizar minimamente por sua vida psíquica e social, deva reconhecer o fato sofrido de que seus infortúnios, ainda que instigados ou causados por fatores sociais objetivos, possuem sua assunção, são de certo modo seus, trabalho psíquico que ele evita porque o põe novamente de frente à sociedade totalitária, porque o coloca nessa zona de contato na qual precisamente se encontram as causas profundas do seu adoecimento, fazendo-o rememorar uma luta cujo resultado lhe foi desfavorável e cuja perspectiva futura não é de inversão desse quadro.

${ }^{186}$ ROUDINESCO, Elisabeth. Por que a psicanálise? Rio de Janeiro: Jorge Zahar, 2000, p. 18-19.

187 Ibidem, p. 17.

188 ADORNO, Theodor \& HORKHEIMER, Max. Dialética do esclarecimento. Rio de Janeiro: Jorge Zahar. $2^{\mathrm{a}}$ edição, 2006 [1947], p. 50. 
Deixo de compreender que minhas vicissitudes são mediadas social e psiquicamente - o que implica certa disposição de encarar e lidar com aquilo que sou eu e ao mesmo tempo não sou eu, com o mundo hostil que me constrange e domina - e passo a interpretá-las como sendo minhas, mas sem que eu tenha responsabilidade sobre elas, sem que eu tenha meios de agir subjetivamente em relação a elas ou de pensá-las, uma vez que são determinadas por um órgão, pelo meu cérebro que, longe de responder aos meus desejos e ações, é resultado da minha carga genética e de algumas pinceladas do ambiente em minha imensa rede neuronal. Há um forte conteúdo de renúncia e submissão aqui.

Identificar-se ao cérebro é identificar-se à realidade, é abandonar-se ao movimento cego da totalidade, como um corpo perdido no oceano. Por conseguinte, se há "algo de despótico na posição que o cérebro ocupa hoje" ${ }^{189}$, se "ele surge como um déspota que domina nossa subjetividade, um órgão imperador que rege estados de humor e define a nossa identidade" ${ }^{190}$, a cerebralização do sujeito por ele mesmo se trata de uma reação subjetiva (conformada) ao despotismo da realidade social. Atenuase o despotismo do real em relação ao qual posso resistir com meu $e u$, com minhas ideias, meus pensamentos e minhas ações, embora isso me custe muito, traduzindo-o em um despotismo para o qual me entrego sem mais, porque é natural, porque se deve à minha constituição biológica.

A cerebralização do sujeito por ele mesmo é um modo de evitar o conflito, ou antes, evitar lembrá-lo, pois só lembrar já é insuportável, apenas pensar em pensar é angustiante. Cerebralizar-se é retirar de si qualquer aspecto conflitivo, retirar-se da zona de contato com o geral que pressiona, esfola, esgarça, intimida entregando-se a ele. É deixar de se responsabilizar (responder por) por sua vida psíquica e por sua existência social, é "escolher" não se contrapor, não criticar, não ser e ir contra, não resistir e encarar as causas reais dos infortúnios.

Em síntese, a reificada concepção neurocientífica de homem reflete na teoria a liquidação do sujeito na prática, sendo que essa liquidação, por sua vez, impele os indivíduos à aceitação dessa imagem empobrecida de homem, impele-os à renúncia da sua condição de sujeito, à regressão auto-imposta.

\footnotetext{
${ }^{189}$ AZIZE, Rogério A nova ordem cerebral: a concepção de 'pessoa' na difusão neurocientífica. Tese de doutorado em Antropologia Social, Museu Nacional, 2010, p. 6.

${ }^{190}$ Ibidem, p. 6.
} 
A reificação da sociedade e do indivíduo condiciona a da teoria que, em um círculo vicioso, retroalimenta a reificação original da vida efetiva. $\mathrm{O}$ modo como isso acontece, isto é, os efeitos sociais, políticos e psíquicos da aceitação da concepção neurocientífica de homem, serão esboçados a seguir. 


\section{Capítulo 3}

\section{A crítica dos possíveis efeitos sociais, políticos e psíquicos do sucesso da concepção neurocientífica de homem}

Ao mudar de humanidade, abalamos as nossas grades de avaliação moral e jurídica. Devemos ficar contentes? Devemos lamentar? Cumpre primeiro constatar, procurar as razões e medir os efeitos. Pois da resposta à pergunta "O que é o homem?" depende, talvez, tudo o que podemos conhecer e tudo o que devemos fazer.

Francis Wolff, Nossa Humanidade, 2012

Quando se afirma ao homem que ele é natureza e nada mais que natureza, ele se torna, no melhor dos casos, objeto de pena. Passivo, como tudo o que é natureza, espera-se que ele seja um objeto de "tratamento", um ser por fim dependente de uma liderança mais ou menos benevolente.

As teorias que fracassam em diferenciar o espírito da natureza objetiva, e que o definem pseudocientificamente como natureza, esquecem que o espírito também se tornou não natureza, que, mesmo que não fosse nada mais que um reflexo da natureza, ele ainda assim transcende o hinc et hunc. Excluir essa qualidade do espírito - a de que ele é, a um só tempo, idêntico à e diferente da natureza - conduz diretamente à visão de que o homem não é essencialmente nada mais do que um elemento e um objeto de processos naturais cegos.

Max Horkheimer, Eclipse da razão, 1947

Inscrita no movimento de uma globalização econômica que transforma os homens em objetos, a sociedade depressiva não quer mais ouvir falar de culpa nem de sentido íntimo, nem de consciência nem de desejo nem de inconsciente. Quanto mais ela se encerra na lógica narcísica, mais foge da ideia de subjetividade. Só se interessa pelo indivíduo, portanto, para contabilizar seus sucessos, e só se interessa pelo sujeito sofredor para encará-lo como uma vítima. E, se procura incessantemente codificar o déficit, medir a eficiência ou quantificar o trauma, é para nunca mais ter que se interrogar sobre a origem deles.

Elisabeth Roudinesco, Por que a psicanálise?,2000 


\title{
O programa forte das neurociências e a produção de selves-objetivos
}

Como toda ideia do que seja (ou do que pode ser) o homem, a concepção neurocientífica traz consigo atrativos, mas também, vista por outros lados, muitos perigos. No final, nada é tão simples, muito menos social e politicamente neutro, quanto parece inicialmente - ou pretende-se que seja.

O chamado programa forte de neurociências, ao lado da indústria de psicofármacos, das novas tecnologias médicas e da atuação da mídia, tem contribuído para a construção do que tem sido chamado de selves-objetivos, assevera Francisco Ortega $^{191}$.

De acordo com o antropólogo Joseph Dumit, o self-objetivo concerne a ideias, noções, teorias a respeito do nosso corpo ou de nosso cérebro que derivamos de fatos recebidos da ciência e da medicina ${ }^{192}$. Em síntese, o self-objetivo se trata de "uma categoria de pessoa desenvolvida mediante conhecimento expert" ${ }^{193}$, observa Ortega. Segundo ele, a formação de um self-objetivo se dá por meio de um "processo duplo" em que, por um lado, as práticas das ciências médicas e da tecnologia "formam selves mediante a experimentação científica", produzindo " 'fatos' que dizem objetivamente quem somos" e, por outro, "os indivíduos desenvolvem seus próprios selves a partir dos fatos ofertados pelas ciências" 194 :

\begin{abstract}
A noção de self objetivo remete a uma compreensão da subjetividade que tem como ponto de partida discursos técnicos, científicos e médicos sobre a objetividade, ou seja, exprime um oximoro, ao juntar palavras de significados opostos, uma subjetividade objetivada, uma forma de self, na qual a perspectiva fenomenológica e subjetiva da primeira pessoa é reduzida à
\end{abstract}

\footnotetext{
${ }^{191}$ ORTEGA, Francisco. O sujeito cerebral e o movimento da neurodiversidade. Mana, Rio de Janeiro, v. 14, n. 2, 2008, p. 491.

192 DUMIT, Joseph. Picturing Personhood: brains scans and biomedical identity. Princeton: Princeton University Press, 2004, p. 7.

193 ORTEGA, Francisco. O sujeito cerebral e o movimento da neurodiversidade. Mana, Rio de Janeiro, v. 14, n. 2, 2008, p. 491.

194 Ibidem, p. 491.
} 
perspectiva em terceira pessoa exprimida mediante as tecnologias médicas e os discursos e as práticas objetivantes. ${ }^{195}$

Um exemplo interessante para pensar a respeito dessa subjetividade objetivada, experimentada em terceira pessoa, é o caso (ou seria acaso?) protagonizado pelo neurocientista James Fallon.

Tudo se passou em 2005. Fallon, que estudava psicopatas há mais de duas décadas, estava conduzindo um estudo sobre a relação entre a anatomia cerebral e o comportamento de assassinos. Para efeito de comparação, incluiu na pilha de imagens a serem analisadas as tomografias de alguns membros de sua família (que deveriam servir como parâmetro de "normalidade"), incluindo a sua própria. Ao se debruçar sobre elas, encontrou uma que mostrava claros indícios de patologia, como nos piores casos em que havia visto: "O exame mostrava baixa atividade em certas áreas dos lobos frontal e temporal que estão associadas à empatia, moralidade e ao auto-controle"196.

Para surpresa de Fallon, a tomografia em questão era a sua. Incomodado, fez testes adicionais, como um exame de DNA que identificou que ele tinha "genes alelos associados à ausência de empatia e a comportamento agressivo e violento", bem como se submeteu a um teste psicológico utilizado para "avaliar tendências antissociais e psicopáticas, a Robert Hare Checklist" ${ }^{\text {"197. }}$

Depois do curioso acaso, Fallon passou a reconsiderar seu posicionamento no tocante à velha querela a respeito da influência do meio versus a dos genes, uma vez que tem vários traços em comum com psicopatas, só não é criminoso, nunca matou ou estuprou alguém e prefere vencer uma discussão com argumentos em vez de força física $^{198}$.

James Fallon não afirmou, e jamais afirmará, que o estabelecimento genérico e sumário de correlações entre anatomia cerebral e comportamentos (criminosos ou não) é

195 ORTEGA, Francisco. O sujeito cerebral e o movimento da neurodiversidade. Mana, Rio de Janeiro, v. 14, n. 2, 2008, p. 491, grifo nosso.

196 VASCONCELOS, Monica. Pesquisador se descobre psicopata ao analisar o próprio cérebro. BBC Brasil. 24 de dezembro de 2013. Disponível em: <http://www.bbc.com/portuguese/noticias/2013/12/131223_psychopath_inside_mv>. Acesso em: 22 de novembro de 2017.

${ }^{197}$ Ibidem.

198 Ibidem. 
no fundo algo simplista e inconsistente, salvo raras exceções. Todavia, não é isso que seu caso escancara?

Sobre o ocorrido, em sua coluna na Folha de São Paulo, Vladimir Safatle, não sem alguma dose de ironia, concluiu:

\begin{abstract}
Esta história real demonstra a inanidade especulativa primária de certos setores das neurociências. Pois o que Fallon descobriu não foi sua "protopsicopatia" nem a força redentora do amor familiar, mas a simples ausência de relações diretas entre estados cerebrais e "comportamento criminoso".

A neurologia conseguiu identificar áreas do cérebro, como o giro supramarginal, cujas atividades são fundamentais para a empatia e a compaixão. Mas se eu fosse kantiano, lembraria que a apatia e a desconfiança em relação à compaixão são condições, não apenas para a psicopatia e para o comportamento antissocial, mas para todo comportamento moral, já que a universalidade do julgamento moral exige o não envolvimento especial com sujeitos particulares determinados.

Ou seja, o mesmo estado cerebral pode estar na base de dois comportamentos sociais divergentes, o que demonstra que não há causalidade direta alguma entre estado cerebral e comportamento social. Mas admitir tal evidência deixaria muita gente sem emprego. ${ }^{199}$
\end{abstract}

Não apenas Fallon, mas os sujeitos em geral estão se vendo cada vez mais objetivamente, de uma forma cada vez mais desimplicada, distanciada e reificada. Essa tendência fica clara ao se analisar a naturalização da subjetividade na área da saúde mental - campo que se tornou um dos mais privilegiados na discussão acerca da subjetividade.

\title{
A cerebralização do autismo e da depressão: casos para se pensar a reificação e a desresponsabilização dos sujeitos
}

Sabe-se que um terreno fértil - talvez o mais fértil - para discussão do que seja (ou de como "funciona") o homem, foi e continua sendo o da saúde mental. Tendo em vista os debates contemporâneos acerca das origens da subjetividade, onde se digladiam

199 SAFATLE, Vladimir. Neurocientista psicopata. Folha de São Paulo. 31 de dezembro de 2013. Disponível em: http://www1.folha.uol.com.br/colunas/vladimirsafatle/2013/12/1391714neurocientista-psicopata.shtml?loggedpaywall> Acesso em: 22 de novembro de 2017 
correntes da psicanálise, psicologia, biologia, filosofia da mente e medicina, duas patologias (psíquicas para uns, cerebrais para outros) são temas privilegiados: o autismo e a depressão.

Comecemos pelo primeiro. Como bem observou Rossano Cabral Lima, em $A$ cerebralização do autismo: notas preliminares, "mais do que uma disputa acadêmica", o debate sobre a origem orgânica ou psíquica do autismo, "repercute diretamente nos campos da clínica e da política, e merece a atenção de todos que militam na saúde mental pública infantil e juvenil" 200 .

Francis Wolff também discorre sobre essa repercussão. Lima trata dela concentrando-se na literatura de língua inglesa (inclusive a psicanalítica); Wolff, por seu turno, retrata o debate francês. Em ambos os casos é retraçada a "evolução explicativa" do autismo como distúrbio da relação pais-bebê para o autismo-patologia-cerebral.

Desde 1940 (década em que o autismo é descrito pela primeira vez por Leo Kanner), até meados da década de 1970, a hipótese psicogênica foi predominante ${ }^{201}$. Nesse momento, o saber psicanalítico influenciava fortemente a psiquiatria ocidental:

\begin{abstract}
Autores como Margareth Mahler, Francis Tustin, Bruno Bettleheim e Donald Meltzer ajudaram a construir a noção de que o autismo era um transtorno localizado nas fundações psíquicas do indivíduo, causados por anomalias no estabelecimento de suas relações objetais precoces, especialmente com as figuras parentais ${ }^{202}$.
\end{abstract}

Atualmente, a situação não é mais essa. A partir do fim dos anos 1970, a ideia de que o autismo tem origem orgânica (genética) e é causado por alterações cerebrais ganhou terreno e tornou-se uma "verdade científica" ${ }^{203}$. Como destacou Lima, essa mudança de paradigma "foi apoiada - e em boa parte patrocinada - por pais e familiares de autistas, que se mostravam descontentes com a 'culpabilização' que o saber

200 LIMA, Rossano Cabral. A cerebralização do autismo: notas preliminares. Em: COUTO, Maria Cristina Ventura e MARTINEZ, Renata Gomes (orgs.). Saúde Mental e Saúde Pública: questões para a agenda da reforma psiquiátrica. NUPPSAM/IPUB/UFRJ, Rio de Janeiro, 2007, p.55.

201 Ibidem, p.56.

202 Ibidem, p. 56.

${ }^{203}$ Aspas ao mesmo tempo de cautela e ironia, já que longe de uma explicação neurocientífica cabal para o autismo, o que se vê é um enxurrada de teorias que pouco conversam entre si. Explicações neurocientíficas sobre o autismo vão da constituição da flora bacteriana intestinal à má-formação (em alguns casos avaliadas em termos quantitativos, portanto de déficit ou excesso, em outras casos em termos qualitativos, como constituição celular diferenciada) de tipos específicos de neurônios. 
psicanalítico e sua popularização teriam lhes imputado". Como consequência, o autismo deixou de ser tratado como uma psicose da infância (como era na $9^{a}$ edição da Classificação Internacional de Doenças da Organização Mundial da Saúde, a CID-9, de 1977) e passou a ser tratado como Transtorno Global do Desenvolvimento ${ }^{204}$.

O caso francês é discutido por Wolff a partir da confrontação entre a "figura estrutural de homem" (que ele vincula a nomes como Claude Lévi-Strauss, Jacques Lacan e Pierre Bourdieu) e a figura do "homem neuronal" (título do livro de Jean-Pierre Changeux). O movimento é o mesmo descrito por Lima: em questão de três décadas a patologia sofreu transformações conceituais radicais, o que teve efeitos igualmente radicais dos pontos de vistas ético, político e clínico:

\begin{abstract}
Na época do "homem estrutural", na França, o autismo era da competência da Psicanálise: era uma "doença mental" catalogada entre as "psicoses". A fortaleza vazia, de Bruno Bettelheim, e sua noção de "mães geladeiras", tomada de Léo Kanner (o inventor da síndrome de "autismo infantil precoce"), faziam autoridade. Os lacanianos propunham diversos conceitos descritivos ou explicativos que, todos eles, relacionavam o autismo a uma falha na relação com a mãe (com seu "significado"), a uma carência da simbolização primária etc. Uma ou duas gerações mais tarde, na era do "homem neuronal", a Alta Autoridade em Saúde e a Federação Francesa de Psiquiatria, reportando-se à classificação das doenças pela Organização Mundial da Saúde, o CID 10, recomendaram, em outubro de 2005, que se passasse a considerar o autismo uma perturbação ligada ao desenvolvimento neurológico. Do mesmo modo, em dezembro de 2007, a Comunidade Europeia definiu o autismo como uma patologia de origem biológica ${ }^{205}$.
\end{abstract}

Segundo Wolff, o parecer 102 do Comitê Consultivo Nacional de Ética da França, de novembro de 2007, denuncia o "escândalo francês", fazendo referência à culpabilização das mães e seu sufocamento pela angústia, devidos ao peso que tiveram na França e em alguns países da América Latina, “a explicação psicanalítica [...] bem como a resistência singular que a Psicanálise continua a opor à classificação internacionalmente aceita do autismo", a saber, "como "perturbação invasiva do

204 LIMA, Rossano Cabral. A cerebralização do autismo: notas preliminares. Em: COUTO, Maria Cristina Ventura e MARTINEZ, Renata Gomes (orgs.). Saúde Mental e Saúde Pública: questões para a agenda da reforma psiquiátrica. NUPPSAM/IPUB/UFRJ, Rio de Janeiro, 2007, p 57.

${ }^{205}$ WOLFF, Francis. Nossa humanidade: de Aristóteles às neurociências. São Paulo: UNESP, 2012, p. 8. 
comportamento' de origem orgânica e neurobiológica” ${ }^{206}$. Diz trecho do relatório, citado por Wolff:

O drama do autismo representa um exemplo particularmente doloroso das consequências que podem ter as teorias sobre as causas de uma deficiência ou de uma enfermidade em termos de sofrimento humano e de respeito à pessoa. As teorias psicanalíticas sobre o autismo [...] propostas na década de 1950 para descreverem e explicarem o mundo interior das crianças atingidas pelo autismo, levaram ao questionamento do comportamento dos pais, e em particular das mães, descritas como "mães geladeiras", "mães mortíferas" no desenvolvimento da deficiência. Considerar a mãe culpada pela deficiência do filho, cortar os laços da criança com a mãe, aguardar que a criança exprima o desejo de contato com o terapeuta, quando ele tem um medo pânico do que o rodeia, dão a medida da violência provocada por tal atitude, dos sofrimentos que ela causou e do impasse a que tal teoria levou em matéria de acompanhamento, de tratamento e de inserção social. ${ }^{207}$

Wolff continua citando o relatório, que no limite defende que aceitar a nova classificação, além de ter permitido o desenvolvimento de novos métodos de tratamento e de inserção social, possibilitou aliviar o sofrimento das famílias. Desse modo, conclui ele que:

[...] No caso do autismo, a explicação pelo determinismo natural tem - sem paradoxo - efeitos reconfortantes, enquanto, pelo determinismo familiar ou social, tem efeitos angustiantes. Pois o que é inato e congênito não pode dever-se a quem quer que seja, nem sequer àquele - ou àquela - que faça "mal" sem querer "fazer mal". Agora vão ter pena dos pais da criança autista - portanto deficiente -, enquanto se olhava com hostilidade os que não haviam sabido amar (ou acolher) uma criança - a qual, consequentemente, se havia "fechado" no autismo ${ }^{208}$

Nesse sentido, para Wolff a naturalização do autismo "permitiu liberalizar a maneira como ele era considerado e tratado"209, isto é, a naturalização, nesse caso, é propiciadora de liberdade àqueles que sofrem (pois que retiram o peso do que até aqui se chamou de culpa).

\footnotetext{
${ }^{206}$ WOLFF, Francis. Nossa humanidade: de Aristóteles às neurociências. São Paulo: UNESP, 2012, p. 256.

${ }^{207}$ Ibidem, p. 257.

${ }^{208}$ Ibidem, p.257, grifo meu.

${ }^{209}$ Ibidem, p. 258.
} 
Pois bem, se há sentimento de culpa nesses casos, e em geral pode-se dizer que há mesmo, o tratamento psicanalítico tanto da criança quanto dos pais (caso estes busquem essa alternativa também para si) deve contribuir para pôr fim a ela, posto que atrevendo-me a falar de uma área que não é a minha - o objetivo da análise é possibilitar que se instaure uma mudança de posição subjetiva dos pais em relação à criança, permitindo que se instalem condições para o advento de um sujeito no infante, ou caso isto já tenha acontecido, embora de modo precário (caso contrário não haveria motivos para se falar em patologia), para que este pequeno sujeito com dificuldades de inscrever-se nos laços sociais e linguísticos possa posicionar-se de outra maneira em relação ao mundo.

Esses deslocamentos (da posição subjetiva dos pais em relação à criança e da criança em relação aos pais e ao mundo), não se dão com base em uma "pretensa culpa" presa ao passado, mas numa aposta subjetiva no desenvolvimento psíquico da criança, na antecipação (pelos pais) de um sujeito onde ainda não há um - por se tratar de uma aposta, volta-se para o futuro, portanto.

Por isso, me parece um engano atribuir a culpabilização à psicanálise (quando ela é dos próprios pais), pois longe de culpar ela responsabiliza os pais, o que é diferente. Barbaridades e absurdos foram e continuam sendo cometidos em nome das mais variadas teorias, ideologias, filosofias etc. Não é de se duvidar que trabalhos ruins tenham sido oferecidos pelo viés psicanalítico, trabalhos que realmente tenham se desenrolado no sentido de culpar os pais ou atá-los à culpa que carregavam fazendo-os se afogar nela. Todavia, o que está em questão é que a visão psicanalítica do autismo não opera no sentido de culpar. O que ocorre, é a responsabilização dos pais. Responsabilizar não se trata de imputar causas ou motivos, mas de suscitar um posicionamento subjetivo frente ao quadro da criança, o que equivale a dizer que se trata de implicar os pais, de elaborar questionamentos e não de supliciá-los.

Renato Janine Ribeiro tem considerações sobre o conceito de responsabilidade que são esclarecedoras nesse sentido. $\mathrm{Na}$ ocasião em que argumentou que as pesquisas biológicas se beneficiam de uma maior disposição do homem a se considerar coisa, lidando assim com suas questões como se fosse um objeto em vez de um sujeito que deveria se responsabilizar por elas, ele remeteu a questão a um estudo de Jorge Forbes (cuja referência não foi apresentada) sobre a responsabilidade na psicologia. Segundo 
ele, Forbes analisou um panfleto publicitário de um laboratório farmacêutico que diz ao deprimido que a depressão que você sente "não é você, é uma doença que pode ser tratada com o remédio tal" ${ }^{210}$. Segundo Janine Ribeiro, Forbes diz que assim a pessoa se desresponsabiliza de sua vida psíquica e conclui: "não é possível um tratamento psicológico adequado se o paciente não assumir a responsabilidade por sua psique",211.

Em outro artigo, Da responsabilidade na psicanálise, Janine lança mão de um exemplo interessante para que se pense a este respeito:

\begin{abstract}
Um processo de responsabilização o fará responder por atos que talvez não tenha cometido com tanta liberdade. Um exemplo nos ajudará: imaginemos uma pessoa que, sem querer, atropela alguém, que se lançou à sua frente. Do ponto de vista legal, o motorista é inocente. Não podia agir de outra forma. Porém, do ponto de vista psicológico, ele terá que lidar com tal acidente. Pode até se convencer, e com razão, de que não deliberou matar. Foi uma desgraça que afetou tanto a ele como à vítima. Mas esse drama se incorpora à sua biografia, à sua psique: faz parte dele. Se com muita rapidez se isentar da culpa, se afirmar o que a lei diz, o que a razão entende, ou seja, que o que ocorreu não foi sua intenção, nem sua negligência ou imperícia, mas um acaso desgraçado, estará deixando de explicitar uma vivência fundamental - e pagará por ela. Penso que é este um dos sentidos do Édipo. Na segunda peça de Sófocles que o tem por protagonista, Édipo em Colona, que pouquíssimos leem, o personagem-título profere um discurso muito moderno. Afinal, diz ele, matei um velho a quem não conhecia, de quem não podia saber que era meu pai e que, além do mais, duas vezes, na infância e de novo na idade adulta, tentou me matar. O que sofri por isso já foi demais! E é claro que ele tem razão, mas psicologicamente só a tem após o luto, após sofrer tudo o que precisou padecer - o que, aliás, é o caso. É como se esse discurso só pudesse ser pronunciado ao termo de suas dores e andanças, mas fique claro que tudo o que ele sofreu não foi por culpa: foi por assim ser a psique. Édipo Rei, em contraste, mas não em contradição, marca a dor por uma culpa que não é de nossa autoria, mas que sobre nós desaba. É claro que Freud revisita Sófocles, modifica-o, mas a ideia que é comum aos dois talvez seja esta: a de uma enorme responsabilidade que se sente, e que no entanto não decorre de nossa ação ${ }^{212}$.
\end{abstract}

No mesmo artigo, vale-se de outro exemplo, este emprestado do romance Tia Júlia e o escrevinhador, de Mario Vargas Llosa. Nele, um motorista peruano atropela de

\footnotetext{
${ }^{210}$ RIBEIRO, Renato Janine. Novas fronteiras entre natureza e cultura. Em: ADAUTO, Novaes (org). O Homem- Máquina: a ciência manipula o corpo. São Paulo: Companhia das Letras, 2003, p. 24.

${ }^{211}$ Ibidem, p. 24.

${ }^{212}$ RIBEIRO, Renato Janine. Da responsabilidade na psicanálise. São Paulo, 1998. Disponível em: <http://www.renatojanine.pro.br>. Acesso em: dezembro de 2014. Disponível também em: $<$ http://psicanaliselacaniana.blogspot.com.br/2012/07/da-responsabilidade-na-psicanalise.html>.
} 
modo involuntário uma criança, e por desespero se vê impedido de voltar a dirigir. Como o sujeito é caixeiro-viajante, sua vida é por demais afetada, até que encontra uma psicóloga: "o eixo do tratamento [...] consiste em responsabilizá-lo pelo atropelamento e negar em absoluto que este tivesse sido casual. Dessa maneira, ela consegue curá-lo”.

Desse modo, a responsabilidade é entendida como a causa ou a condição da liberdade, ao contrário da ideia moderna e burguesa de responsabilidade, em que a liberdade é que produz a responsabilidade, obedecendo à fórmula "sou livre e respondo pelas consequências das minhas ações". Aqui, trata-se de algo inverso, da responsabilidade como meio de se tornar livre:

Aliás, quando chegamos à chamada idade da razão, o que fazemos senão começar a enfeixar os fios soltos das escolhas que nos precederam, das eleições alheias e dos acasos que nos antecederam, e que agora assumimos como nossos para nos tornarmos, justamente, nós? Não elegemos nosso sexo, a família em que nascemos. Tudo isto independe de nós; contudo, só conseguiremos fazer algo se assumirmos esse conjunto de elementos díspares como nossa identidade. Assumir uma identidade significa assim assumir uma identidade inicialmente constituída para nós, e arcar com a responsabilidade por essa identidade forjada pelo outro, e que em certa medida até o fim da vida continuará sendo engendrada pelo que nos rodeia. Mas só a partir daí poderemos negociar a liberdade, entendendo que se trata de uma liberdade constituída, e não de uma liberdade dada ou ofertada: esta pode muito nos atrair, mas não existe. ${ }^{213}$

Bem diferente da visão jurídica de responsabilidade, que sempre pressupõe um sujeito estabelecido, pronto e acabado, a responsabilidade na psicanálise, na acepção de Janine Ribeiro, é o alicerce do sujeito, é uma das condições de seu desenvolvimento. Assim, deve-se pensar a responsabilidade não como o final (o que acontece no Direito), mas como um começo:

Ela será a forma pela qual assumimos o que foi hetero-escolhido antes de nossa idade adulta, e que, gostemos ou não, é uma história inegavelmente nossa, a qual podemos mudar, mas não arbitrariamente, e sim a partir do modo por que fomos constituídos - e a qual não podemos denegar. ${ }^{214}$

213 RIBEIRO, Renato Janine. Da responsabilidade na psicanálise. São Paulo, 1998. Disponível em: $<$ http://www.renatojanine.pro.br>. Acesso em: dezembro de 2014.

${ }^{214}$ Ibidem. 
Se se responsabilizar é responder a algo (sendo esse algo dependente ou independente de nosso desejo, seja resultado ou não de escolhas livres e conscientes), os pais de crianças autistas não escapam disso, mesmo aderindo à tese cerebral. $O$ problema se encontra no tipo de resposta que pode ser dada pela via naturalista: uma resposta objetiva, desimplicada subjetivamente. E é justamente essa indisposição dos sujeitos de se responsabilizarem por suas vidas que se encontra intimamente vinculada à questão da cerebralização.

O que tem acontecido no caso do autismo, pois, é a adesão massiva das famílias a tratamentos que esvaziam o assunto de toda subjetividade que lhe é incontestavelmente inerente, como toda a sorte de terapias cognitivo-comportamentais, com suas análises do comportamento, com seus programas e treinos a serem objetivamente executados $^{215}$.

Ao contrário dessas terapias, nas quais as famílias têm atendidas suas demandas de "estimulação" da criança, encontrando aí receitas prontas do que fazer, no modelo psicanalítico, “[...] mais que respostas formulam-se questões, mais que uma prescrição busca-se uma construção e [...] a estimulação só pode ser pensada quando pressupõe um sujeito no bebê" ${ }^{216}$. Em poucas palavras, o tratamento psicanalítico do autismo depende da possibilidade dos pais se questionarem e se implicarem, isto é, responsabilizarem-se — no sentido exposto por Janine.

Posto isso, pode-se dizer que as figuras parentais, pais ou mães, não são culpados pela condição autística dos filhos, mas que são responsáveis por ela, sendo uma coisa muito diferente da outra. É algo a que eles precisam responder, implicando a configuração familiar, implicando-se de alguma forma na situação da criança, em sua história. E mesmo que suponhamos que fosse flagrante a "natureza cerebral" do autismo, isso em nada mudaria o quadro: os pais continuam (pelo menos deveriam

\footnotetext{
${ }^{215}$ Não defendo aqui a redução dessa perspectiva a pó. O que seria fácil de fazer, por um lado, mas irresponsável, por outro. Não há dúvidas a respeito da importância de tais terapias para o desenvolvimento de crianças com os mais variados transtornos do desenvolvimento. No entanto, o fato de servirem em alguma medida ao desenvolvimento das crianças, não as exime de serem questionadas pelos efeitos negativos que produzem. Sim, trata-se de um paradoxo. Espero ter deixado claro o problema que estou discutindo: a objetividade do enfoque naturalista se dá à custa do apagamento da subjetividade, o que é gravíssimo e, portanto, deve ser debatido.

216 TEPERMAN, Daniel Waldman. Clínica Psicanalítica com bebês: uma intervenção a tempo. São Paulo: Casa do Psicólogo/FAPESP, 2005, p. 97.
} 
continuar) responsáveis pelo autismo de seus filhos, ou melhor dizendo, pelos seus filhos; continuam tendo que responder subjetivamente a isso.

Portanto, tal liberdade ou liberalização que a naturalização oferece, é uma falsa liberdade, é um encobrimento, seja o autismo considerado de que forma for. Em seu âmago está a dificuldade acachapante do sujeito em se responsabilizar por sua vida e a de seus, incapacidade que resulta diretamente da crise da subjetividade na sociedade contemporânea. As pessoas não têm sido mais capazes de se posicionarem como sujeitos frente à realidade objetiva, sejam pais de crianças autistas, sejam pessoas com os mais variados dramas pessoais, tenham eles ou não a ver especificamente com o sofrimento mental.

A meu ver, a resistência singular que a psicanálise opõe à tese cerebral é em algum grau heróica, no sentido de que talvez aja como instância de preservação da subjetividade em um mundo em que ela tem sido liquidada em diversas frentes, e que, tendo em vista uma psicanálise que não se configura como psicoterapia voltada à adaptação, ainda se preserve como um espaço em que o sujeito possa se responsabilizar por sua vida e a de seus, de que possa se reinventar e encarar de algum modo o mundo reificado de que fazemos parte e colaboramos para reproduzir.

Isso me leva à posição privilegiada do psicanalista Jorge Forbes. Privilegiada porque ele é responsável, desde 2006, pela Clínica de Psicanálise do Centro do Genoma Humano da Universidade de São Paulo (segundo ele, a única do gênero até o momento ${ }^{217}$ ), lugar onde se "chocam" os dois modos de ver de que temos tratado: o biológico (no caso representado pela Genética) ${ }^{218}$ e o psicanalítico.

Para Forbes, o homem sempre buscou um lugar onde estaria escrita sua história. Se ontem era nas estrelas, o que o levava e ainda leva a consultar astrólogos, hoje é no

\footnotetext{
${ }^{217}$ Forbes escreveu isso em 2012. Cf. FORBES, Jorge. Inconsciente e responsabilidade: psicanálise do século XXI. Barueri: Manole, 2012, p. 105.

${ }^{218}$ Devo fazer uma importante ressalva: ainda que eu já tenha dado muitos indícios da maneira redutora como muitos pensam e trabalham do lado da lógica naturalista das neurociências, a experiência de Forbes na clínica do Centro do Genoma Humano tem se dado no sentido contrário, o que aparece cristalizado em um diálogo seu com a diretora do Centro, a conhecida geneticista Mayana Zatz, (na ocasião em que iniciava o projeto da clinica psicanalítica). Forbes pergunta se ela crê numa relação biunívoca entre o genótipo e o fenótipo, a que ela responde "claro que não" e pergunta "quem lhe disse tamanha besteira?". Já de volta ao livro, Forbes confessa que a resposta foi uma grata surpresa, pois muitos acreditam nessa besteira.
} 
genoma; é no sequenciamento dos genes humanos que ele busca o conforto do Maktoub, que lhe retira a responsabilidade acerca de seu destino ${ }^{219}$.

$\mathrm{Na}$ primeira pesquisa realizada no Centro, "a partir de um diagnóstico situacional do sofrimento reportado pelos pacientes e pelos geneticistas", sua equipe detectou "um novo e verdadeiro vírus do laço social" que denominara de "RC, iniciais de Resignação e Compaixão. Resignação dos pacientes; Compaixão das famílias”. Tendo sido anunciada à pessoa uma doença futura, da qual ela não sofre ainda, o sujeito escolhe alienar-se em um sofrimento prêt-à-porter:

\begin{abstract}
Ao adotar tal atitude, o sujeito deixa a porta aberta a dois problemas. Primeiro, resignando-se, ele antecipa o sofrimento e facilita por essa antecipação o progresso da doença anunciada. Segundo, do lado da família, justaposta à resignação surge a compaixão que, sob sua face de virtude, esconde o vício da acomodação indiferente, congelando a situação em um dueto dor-piedade. É por isso que intitulamos nossa pesquisa de "Desautorizar o sofrimento", entenda-se com isso o sofrimento padronizado $^{220}$.
\end{abstract}

Com isso, Forbes e sua equipe perceberam que era possível uma ação psicanalítica com esses pacientes, "retirando-lhes a segurança da solução prêt-à-porter e devolvendo-lhes a surpresa do encontro que eles haviam tido em suas vidas com aquele terrível veredito",221.

Com o auxílio do que foi dito por Janine Ribeiro e Forbes, é possível concluir alguns aspectos a respeito da cerebralização do autismo (e de toda subjetividade). $\mathrm{O}$ diagnóstico, na chave naturalista, é reconfortante, desresponsabiliza os pais e os levam a se entregar ao sofrimento padronizado, à profecia que se auto-realiza, à fria resignação obstando a possibilidade subjetiva de dar respostas, de enxergar e se valer da possibilidade de mudanças, de suscitar movimentos.

No caso de Forbes na Clinica psicanalítica do Centro do Genoma Humano da Universidade de São Paulo, trata-se de doenças cuja natureza biológica é incontestável. Ainda assim, a experiência de sua clínica demonstrou a existência de uma margem de ação subjetiva, uma vez que parece não haver uma relação de determinação biunívoca

\footnotetext{
${ }^{219}$ FORBES, Jorge. Inconsciente e responsabilidade: psicanálise do século XXI. Barueri: Manole, 2012, p. 104.

${ }^{220}$ Ibidem, p. 107.

${ }^{221}$ Ibidem, p. 107.
} 
entre genótipo e fenótipo. Isto me faz pensar no caso das neurociências e na consequente naturalização da psiquiatria, pois a natureza biológica das patologias por eles tratada como algo indiscutível, na verdade, é muito discutível, havendo nexos causais psíquicos e sociais flagrantes. Neste caso, os efeitos das respostas subjetivas, calcadas na responsabilidade, teriam uma margem maior ainda de ação? Não teriam um alcance a mais, isto é, efeitos políticos e sociais?

Abordemos o caso da depressão pelo viés das neurociências. Se a discussão sobre o autismo possibilitou o desenvolvimento dos argumentos a respeito da desresponsabilização subjetiva levada a cabo pela cerebralização dos sujeitos, a visão neurocientífica da depressão possibilita que se enxergue de modo mais claro os efeitos sociais e políticos da cerebralização da subjetividade.

Desde 2000, a neurocientista Suzana Herculano-Houzel mantinha uma página na internet (com auxilio do CNPQ) intitulada O cérebro nosso de cada dia. Hoje ela já não se encontra no ar (meu último acesso foi em 2013). Entre muitas curiosidades, artigos e entrevistas, todas com o objetivo de difundir ao público leigo as novidades da neurociência contemporânea, guardo em meu arquivo pessoal uma entrevista que o neurocientista Ivan Izquierdo concedeu a ela. Em dada altura, quando conversavam sobre as pesquisas de Izquierdo relativas às bases neuronais da memória, dá-se o seguinte diálogo:

SUZANA: - Você acha que a depressão pode estar relacionada com a
dificuldade de esquecer coisas ruins, ou também de não se
lembrar de coisas boas? IVAN IZQUIERDO: — As duas coisas. Sem dúvida as duas coisas! $!^{222}$

Antes de acrescentar mais uma leitura neurocientífica a respeito da depressão, também da autoria de Herculano-Houzel, creio que valha a pena já deixar uma provocação: por que não pensar que a depressão não teria a ver com a incapacidade subjetiva de esquecer coisas ruins, mas com as coisas ruins em si (e seus efeitos sobre os sujeitos)?

${ }^{222}$ Arquivo pessoal 
Em recente artigo no jornal Folha de São Paulo, datado de 17 de janeiro de 2017, cujo título é Ganhei minha vida de volta com o Prozac ${ }^{223}$, Suzana HerculanoHouzel, que deixou recentemente a Universidade Federal do Rio de Janeiro, relata um período conturbado de sua vida. O ano anterior, de 2016, foi difícil para ela: estressada devido aos financiamentos de pesquisa que o governo concedeu (mas não pagou), pela ameaça iminente de ter que fechar o laboratório, viagens sucessivas para os Estados Unidos para realizar entrevistas de emprego, problemas familiares advindos da oferta de cargo que recebeu, o que, por sua vez, gerou preocupações com a burocracia da mudança, com os gastos para montar a casa nova e por aí vai, Suzana constatou que estava sofrendo de ansiedade crônica, e que o quadro estava afetando as pessoas ao seu redor.

Foi salva por uma médica, clínica geral, que lhe sugeriu experimentar Prozac (cujo princípio ativo é o cloridrato de fluoxetina), talvez o mais famoso dos antidepressivos. Ante a enorme lista de tarefas que a estava soterrando, aceitou a sugestão. Herculano-Houzel termina o artigo assim:

\begin{abstract}
Antidepressivos levam cerca de duas semanas para agir, sinal justamente de que o fazem não ao mudar simplesmente a "química" do cérebro, e sim ao iniciar um processo mais lento de recuperação, que requer gerar células novas.

Eu já havia esquecido que tomava o remédio quando, doze dias depois, entrei em um voo de volta de um congresso para casa. Habituada à cabeça gritando constantemente lembretes e planos, estranhei a novidade: ao tomar meu assento e curtir o momento de desligar tudo, o silêncio interior me chamou a atenção. Era uma sensação de paz mental e tranquilidade que eu não conhecia havia mais de um ano.

Sim, a lista de afazeres continua lá - mas meu cérebro não berra mais comigo o tempo todo. Santa neurociência básica e aplicada: ganhei minha vida de volta. ${ }^{224}$
\end{abstract}

É flagrante e patente no relato de Herculano-Houzel, como já fora em seu diálogo com Izquierdo, uma postura de total evitação de questionamentos acerca da

${ }^{223}$ HERCULANO-HOUZEL, Suzana. Ganhei minha vida de volta com o Prozac. Folha de São Paulo. 17 de janeiro de 2017. Disponível em: <http://www1.folha.uol.com.br/colunas/suzanaherculanohouzel/2017/01/1850401-ganhei-minhavida-de-volta-com-o-prozac.shtml?loggedpaywall>. Acesso em: 22 de novembro de 2017.

${ }^{224}$ HERCULANO-HOUZEL, Suzana. Ganhei minha vida de volta com o Prozac. Folha de São Paulo. 17 de janeiro de 2017, grifos meus. Disponível em: <http://www1.folha.uol.com.br/colunas/suzanaherculanohouzel/2017/01/1850401-ganhei-minhavida-de-volta-com-o-prozac.shtml?loggedpaywall>. Acesso em: 22 de novembro de 2017 
própria vida, da sociedade, da história. Consciente ou inconscientemente ela não fez questão de esconder ou camuflar que a objetividade insuportável representada pela sua lista de afazeres está diretamente ligada ao mal-estar que vinha sentindo. Ela apenas abdica de pensá-la e de agir sobre ela, afinal, as coisas a fazer ainda estão lá. Trata-se, neste artigo em especial, de um conformismo que escancara uma tendência aguda de submissão à realidade, de conformação, pois a fuga que a medicação pareceu propiciar nada mais é do que uma anestesia, algo que enfraquece, que desbota a percepção do antagonismo entre indivíduo e sociedade, percepção esta que é elemento vital do desenvolvimento da individualidade.

Nessa direção é comum, por exemplo, lermos ou ouvirmos a expressão "tratamento contra" (depressão, esquizofrenia etc.) em vez de "tratamento da". Entendo com isso (com a ideia de contrariedade), que se trata de uma intervenção contra $a$ manifestação dos sintomas e dos questionamentos que porventura os sujeitos poderiam ser suscitados a fazer devido ao adoecimento, e não um tratamento que privilegie alcançar as causas do sofrimento e suscitar um posicionamento subjetivo em relação a ele e, sobretudo, a elas. Roudinesco é precisa no diagnóstico:

\begin{abstract}
Inscrita no movimento de uma globalização econômica que transforma os homens em objetos, a sociedade depressiva não quer mais ouvir falar de culpa nem de sentido íntimo, nem de consciência nem de desejo nem de inconsciente. Quanto mais ela se encerra na lógica narcísica, mais foge da ideia de subjetividade. Só se interessa pelo indivíduo, portanto, para contabilizar seus sucessos, e só se interessa pelo sujeito sofredor para encarálo como uma vítima. E, se procura incessantemente codificar o déficit, medir a eficiência ou quantificar o trauma, é para nunca mais ter que se interrogar sobre a origem deles ${ }^{225}$.
\end{abstract}

Ao pacificar/anestesiar a tensão entre sujeito e a objetividade social, a visão cerebral de homem e a medicalização que dela decorre acarretam, no polo subjetivo, um incremento da liquidação da subjetividade (à qual o sujeito renuncia) e, no polo objetivo (político e social), a submissão ao mundo tal como ele é, a identificação ao movimento cego da totalidade social.

Dessa evitação, ora cínica, ora encobridora, alimenta-se toda sorte de terapias ultramodernas como o implante de marco passos cerebrais, eletrochoque e "terapias

${ }^{225}$ ROUDINESCO, Elisabeth. Por que a psicanálise? Rio de Janeiro: Jorge Zahar, 2000, p. 42, grifo meu. 
eletromagnéticas". Esse quadro oferecido pelas neurociências e pela medicina parece reforçar a tese de Adorno e Horkheimer segundo a qual "o mito já é esclarecimento e o esclarecimento acaba por reverter à mitologia",226.

\section{A liquidação do sujeito pela cerebralização: desresponsabilização subjetiva, submissão e identificação à realidade}

O psicanalista e professor da Universidade de São Paulo, Christian Dunker, disse recentemente que "escolher o que fazer com seu sofrimento é uma escolha ética e também política" 227 . Pensando no sofrimento como uma experiência antropológica em sentido amplo, sem reduzi-lo à questão da saúde mental, mas também não deixando de englobá-la, quais os efeitos da escolha dos sujeitos contemporâneos pela cerebralização da subjetividade?

Ao discutir que tanto o idealismo quanto o naturalismo filosóficos, não obstante representem dois tipos contraditórios de pensamento, servem aos mesmos propósitos (a saber, a glorificação do existente e de seu poder cego), Horkheimer disse sobre o segundo que:

[...] Quando se afirma ao homem que ele é natureza e nada mais que natureza, ele se torna, no melhor dos casos, objeto de pena. Passivo, como tudo o que é natureza, espera-se que ele seja um objeto de "tratamento", um ser por fim dependente de uma liderança mais ou menos benevolente.

As teorias que fracassam em diferenciar o espírito da natureza objetiva, e que o definem pseudocientificamente como natureza, esquecem que o espírito também se tornou não natureza, que, mesmo que não fosse nada mais que um reflexo da natureza, ele ainda assim transcende o hinc et hunc [aqui e agora]. Excluir essa qualidade do espírito - a de que ele é, a um só tempo, idêntico à e diferente da natureza - conduz diretamente à visão de que o homem não é

${ }^{226}$ ADORNO, Theodor \& HORKHEIMER, Max. Dialética do esclarecimento. Rio de Janeiro: Jorge Zahar. $2^{\mathrm{a}}$ edição, 2006 [1947], p.15.

${ }^{227}$ DUNKER, Christian Ingo Lenz. Políticas de sofrimento. Folha de São Paulo. 06 de outubro de 2017. Disponível em:<http://www1.folha.uol.com.br/opiniao/2017/10/1924752-politicas-desofrimento.shtml> Acesso: 26 novembro de 2017. 
essencialmente nada mais do que um elemento e um objeto de processos naturais cegos. $^{228}$

É nesse sentido que vai a subjetividade se deixada na esteira da ideologia cerebral: o homem se tornando objeto de pena, um elemento objetivo (entre outros) abandonado e entregue ao movimento cego da totalidade social alienada $\mathrm{e}$ desgovernada. Se o sujeito não se responsabiliza, ele não responde à realidade como sujeito, mas apenas como objeto, como mero elemento passivo dessa realidade. E sendo assim, submete-se e identifica-se a ela.

Por que se colocar na condição de sujeito e se responsabilizar pelos infortúnios da vida contemporânea é tão doído e sofrido?

A resposta possível indica que é porque se colocar na condição de sujeito exige se contrapor ao objeto, à sociedade, à história. É ter de lidar com eles, acertas contas tanto do ponto de vista psíquico, quanto dos pontos de vista ético, social e político. Mas não sou eu mesmo que venho enfatizando a ideia de que a superioridade da sociedade sobre o indivíduo atingiu um patamar impensável e insuportável? Pois é justamente aqui que se encontra a origem dessa disposição dos homens de serem tratados como coisas: é insuportável fazer o contrário, posicionar-se como sujeito bem no momento em que a subjetividade encontra-se liquidada, e a objetividade alienada (que exige do homem que ele funcione como coisa) encontra-se descendo a ladeira em "ponto morto" bem em sua própria direção. A pressão para identificar-se é enorme, fazê-lo produz aquela sensação de alívio, no mínimo, ainda que momentâneo.

Sobre a questão da identificação, farei referência mais uma vez a considerações de Renato Janine Ribeiro em seu artigo já bastante citado sobre as novas fronteiras entre natureza e cultura. Antes ainda de discutir os avanços da biologia, ele discorreu sobre a diferença epistemológica aguda que distingue as ciências naturais das ciências humanas: as últimas "partem do escândalo que é o ser humano conhecer a si próprio, misturando as posições de sujeito e objeto" 229 . Para Janine Ribeiro quem mais bem intuiu esse problema foi Jean-Jacques Rousseau, como observou Claude Lévi-Strauss em Jean-

\footnotetext{
${ }^{228}$ HORKHEIMER, Max. Eclipse da Razão. São Paulo: Unesp, 2015 [1947], p. 187-188.

${ }^{229}$ RIBEIRO, Renato Janine. Novas fronteiras entre natureza e cultura. Em: ADAUTO, Novaes (org). O Homem- Máquina: a ciência manipula o corpo. São Paulo: Companhia das Letras, 2003, p. 17.
} 
Jacques Rousseau, fundador das ciências do homem ${ }^{230}$. Na leitura que Janine faz de Lévi-Strauss, "a recusa da separação entre sujeito e objeto" é o que constitui as ciências do homem ${ }^{231}$. Nas palavras de Lévi-Strauss, Rousseau "descobriu na identificação o verdadeiro princípio das ciências humanas" ${ }^{232}$.

Para discutir esse pensamento, ambos utilizam-se dos relatos das caminhadas de Rousseau em seus Devaneios do caminhante Solitário ${ }^{233}$, Janine discutindo aspectos da segunda e da quinta caminhadas, Lévi-Strauss, da primeira, da segunda e da sétima.

Na segunda caminhada, Rousseau narra que ao caminhar distraído foi derrubado por um grande cachorro dinamarquês. Perdeu a consciência e era quase noite quando recuperou os sentidos. Ao acordar, sente-se bem:

[...] Nascia para a vida naquele instante e me parecia preencher com minha leve existência todos os objetos que percebia. Por inteiro no presente, não lembrava de nada, não tinha uma noção distinta de meu indivíduo, nem a mínima ideia do que acabara de acontecer, não sabia quem era ou onde estava; não sentia nem dor, nem medo, nem inquietude. Via meu sangue correr como teria visto correr um riacho, sem sequer pensar que aquele sangue me pertencia de alguma forma. Sentia em todo o meu ser uma calma maravilhosa à qual, cada vez que lembro, não encontro nada de comparável no conjunto dos prazeres conhecidos ${ }^{234}$.

Para Janine, Rousseau "sente-se unido ao mundo que o rodeia. Essa perda da consciência de si, como sendo distinto do mundo, é o melhor que lhe pode ocorrer"235. Na quinta caminhada é possível enxergar o mesmo quadro. Rousseau conta que gostava de sentar-se na beira de um lago quando a noite se aproximava:

Ali o barulho das ondas e a agitação da água, fixando meus sentidos e afastando de minha alma qualquer outra agitação, a mergulhavam em um devaneio delicioso em que muitas vezes a noite me surpreendia sem que eu percebesse. O fluxo e o refluxo dessa água, seu ruído contínuo e retomado a

${ }^{230}$ LÉVI-STRAUSS, Claude. Jean Jacques Rousseau, fundador das ciências do homem. In: Antropologia estrutural dois. São Paulo: CosacNaify, 2003.

${ }^{231}$ RIBEIRO, Renato Janine. Novas fronteiras entre natureza e cultura. Em: ADAUTO, Novaes (org). O Homem- Máquina: a ciência manipula o corpo. São Paulo: Companhia das Letras, 2003, p. 18.

${ }^{232}$ LÉVI-STRAUSS, Claude. Jean Jacques Rousseau, fundador das ciências do homem. In: Antropologia estrutural dois. São Paulo: CosacNaify, 2013, p. 55.

233 A obra é divida em dez caminhadas.

${ }^{234}$ ROUSSEAU, Jean-Jacques. Os devaneios do caminhante solitário. Poro Alegre: L\&PM, 2009, p. 20.

${ }^{235}$ RIBEIRO, Renato Janine. Novas fronteiras entre natureza e cultura. Em: ADAUTO, Novaes (org). O Homem- Máquina: a ciência manipula o corpo. São Paulo: Companhia das Letras, 2003, p. 17. 
cada intervalo, atingindo sem parar meus ouvidos e meus olhos, substituíam os movimentos internos que o devaneio apagava em mim e bastavam para me fazer sentir com prazer minha existência sem me dar ao trabalho de pensar. De tempos em tempos, nascia alguma fraca e pequena reflexão sobre a instabilidade das coisas deste mundo, cuja imagem a superfície das águas me oferecia, mas logo essas impressões ligeiras se apagavam na uniformidade do movimento contínuo que me embalava e que, apesar de nenhuma participação ativa de minha alma, não deixava de me prender, a ponto de, ao ser chamado pela hora e pelo sinal combinado, não conseguir sair dali sem esforço $^{236}$.

Como interpreta Janine, o movimento da água tomava conta de Rousseau, "que perdia totalmente a consciência de si como algo separado do que vê", perda de separação que seria fundamental para ele, pois só ela produz felicidade ${ }^{237}$.

Apesar do alerta de Janine de que tais relatos não parecem tratar de epistemologia, e sim de filosofia prática (discutindo assuntos como, por exemplo, a felicidade), é justamente pelo viés epistemológico que ele e Lévi-Strauss se enveredam.

De outro modo, ocorreu-me pensar as situações de identificação com o mundo descritas por Rousseau nas caminhadas de um ponto de vista prático mesmo, isto é, como ponto de apoio para meu argumento de que a aceitação da concepção neurocientífica de homem pelas pessoas se desdobra em uma identificação regressiva com a sociedade, em conformismo e submissão.

Do ponto de vista efetivo, concreto, a identificação que sobressai dos relatos de Rousseau não é aquela da reconciliação do homem com a natureza, da superação da dominação social, a da identificação a outrem, que esperamos que ocorra no futuro. Não consigo lê-la senão pelo prisma da alienação, ou seja, como uma tentativa de fuga de um mundo inóspito (não podemos nos esquecer das perseguições de que Rousseau foi alvo e de sua relação melancólica para com o mundo), tal qual a que pode ser vista nas tendências entre os jovens de, por meio de inúmeras práticas e filosofias, "conectar-se ao verde", à "natureza", de buscar atingir um "estado elevado do ser", como forma de tranquilizar a alma, de se poupar das infinitas angústias e da agitação histérica típicas da vida moderna. Mais do que isso, tais relatos auxiliam em larga medida na reflexão acerca dos contornos do declínio da subjetividade representada pela cerebralização do

\footnotetext{
${ }^{236}$ ROUSSEAU, Jean-Jacques. Os devaneios do caminhante solitário. Poro Alegre: L\&PM, 2009p. 68

${ }^{237}$ RIBEIRO, Renato Janine. Novas fronteiras entre natureza e cultura. Em: ADAUTO, Novaes (org). O Homem- Máquina: a ciência manipula o corpo. São Paulo: Companhia das Letras, 2003, p. 17.
} 
sujeito por ele mesmo: ao identificar-se à ideia de que seja apenas cérebro, o homem renuncia à sua condição de sujeito, dilui-se no objeto, na objetividade alienada e que corre solta no espaço e no tempo, do mesmo como pelo qual Rousseau sentiu-se fundido ao mundo que o rodeava, experimentando com isso uma maravilhosa sensação de calmaria.

Tratar objetivamente a própria subjetividade é assim menos custoso psiquicamente. O self-objetivo desresponsabiliza, retira o peso, o sujeito trata seu eu como um outro, como terceiro. Desta maneira não encara (ou encara de uma distância segura) seu passado, suas cicatrizes, suas feridas, esquivando-se sempre de estar na zona de contato com a sociedade, com o poder que lhe poda e que lhe exige renúncia a todo tempo e que, em todo o caso, ele alimenta porque depende dele (sujeito) para se reproduzir. A cerebralização é uma solução atomizada para problemas sociais.

Justamente porque a sociedade depende dele para se reproduzir é que o sujeito deve se responsabilizar e, ao mesmo tempo, procurar meios de resistir em alguma medida à pressão do todo sobre as partes. Lembrando que o desenvolvimento do indivíduo não se consegue pela emancipação absoluta da coletividade, já que o desenvolvimento pleno da subjetividade só pode ser resultado do desenvolvimento pleno da sociedade. Pelo contrário, a emancipação individual se dará com a "libertação da sociedade da atomização, uma atomização que pode alcançar seu pico em períodos de coletivização e cultura de massas" 238 , atomização que pode ser incrementada pela difusão da concepção neurocientífica de homem e pelo sujeito quando cerebraliza a si mesmo, desresponsabilizando-se pela sua existência social e renunciando à sua capacidade de resistir.

${ }^{238}$ HORKHEIMER, Max. Eclipse da Razão. São Paulo: Unesp, 2015 [1947], p. 151 


\section{Considerações finais}

Percorrendo as teses, hipóteses, prognósticos, etc. das neurociências, tanto na pena de um importante teórico como Changeux, como nos artigos das revistas e dos jornais, quase se é convencido de que tudo se deve ao cérebro. Sequer se pode dizer que passa pelo sujeito ou pelo indivíduo, entendidos como seres dotados de alguma espontaneidade, que atribuem significados às suas ações, que compartilham representações e valores acerca deste mundo. A humanidade e suas questões estão aquém disso, na universal e completamente indiferenciada carne e nas moléculas que a constituem no plano microscópico.

A ascensão da vaga figura cerebral de homem na esfera da ciência e o sucesso de sua difusão cultural é efeito da reificação da sociedade e do sujeito (do processo de expropriação psicológica), aparecendo como o substituto vantajoso e "natural" (nos dois sentidos do termo) da figura psicológica, assentada principalmente na psicanálise. O vazio da visão neurocientífica de homem é refletido do esvaziamento do homem efetivo, do sujeito regredido típico do mundo administrado das sociedades capitalistas avançadas.

Assim "o progresso da sociedade industrial [...] acaba por destruir a ideia pela qual o todo se justificava: o homem enquanto pessoa [...]"239. Tal ideia está cada vez mais obsoleta, ultrapassada, esquecida, afastada da consciência dos próprios homens. A condição da ascensão das neurociências e da preponderância da concepção neurocientífica de homem reside nesse Alzheimer coletivo:

[...] a dominação perene da natureza, a técnica médica e não médica, tira sua força dessa cegueira; só o esquecimento a tornaria possível. A perda da lembrança como condição transcendental da ciência. Toda reificação é um esquecimento $^{240}$.

\footnotetext{
239 ADORNO, Theodor \& HORKHEIMER, Max. Dialética do esclarecimento. Rio de Janeiro: Jorge Zahar. 2 edição, 2006 [1947] p. 168

240 Ibidem, p. 190.
} 
Trata-se da efetivação das previsões do cientista político estadunidense Francis Fukuyama que, de acordo com Roudinesco, “se regozija com o 'desaparecimento' da psicanálise, da história [...] em prol do advento de uma sociedade baseada na ciência natural e que teria abolido o próprio homem?"241. Diz Fukuyama que "nesse estágio, teremos acabado definitivamente com a história humana, porque teremos abolido os seres humanos como tais. Começará então uma nova história, para além do humano" ${ }^{242}$. Ainda não é o caso, penso eu. Contudo, não podemos deixar de notar que se trata de uma possibilidade histórica efetiva, o que exige nossa atenção.

Entretanto, a regressão da sociedade e do sujeito de que nos falam Adorno e Horkheimer, a qual é visível no quadro pintado por Fukuyama, não se tornará realidade única e exclusivamente pela via da naturalização (entendida como o avanço da lógica biologicista). Ainda que ela pareça despontar como traço cultural essencial do período em que vivemos, a biologização não é o único modo de responder subjetivamente à racionalização e ao caráter administrativo da sociedade, logo - é preciso ser justo -, devo reforçar que a cerebralização do sujeito por ele mesmo não é a única forma em que se apresenta a crise atual da subjetividade.

É possível observar na cerebralização do sujeito por ele mesmo uma forma de terceirização das causas e das possibilidades de resposta ao sofrimento e aos infortúnios tanto quanto o é nas tendências de atribuir nossas trajetórias (bem como as dificuldades inerentes e as possibilidades de mudança) aos desígnios do(s) demônio(s), deuses, do pai, da mãe, dos irmãos ou irmãs, do parceiro amoroso, dos genes, dos astros, da sociedade etc.

A própria sociologia não está imune à produção de discursos que igualmente levam à desresponsabilização do sujeito e ao conformismo. Sua mensagem pode ser lida da mesma maneira. Cito Pierre Bourdieu, para mostrar como isso pode acontecer:

Levar à consciência os mecanismos que tornam a vida dolorosa, inviável até, não é neutralizá-los: explicar as contradições não é resolvê-las. Mas, por mais cético que se possa ser sobre a eficácia da mensagem sociológica, não se pode anular o efeito que ela pode exercer ao permitir aos que sofrem que descubram a possibilidade de atribuir o seu sofrimento a causas sociais e

${ }^{241}$ Cf. ROUDINESCO, Elisabeth. Por que a psicanálise? Rio de Janeiro: Jorge Zahar, 2000, p. 61.

242 FUKUYAMA, Francis. La fin de l'histoire, dix ans après. Le Monde, 17 de junho de 1999 apud ROUDINESCO, Elisabeth. Por que a psicanálise? Rio de Janeiro: Jorge Zahar, 2000, p. 62. 
assim se sentirem desculpados; e fazendo conhecer amplamente a origem social, coletivamente oculta, da infelicidade sob todas as suas formas, inclusive as mais íntimas e as mais secretas ${ }^{243}$.

Não se trata da intenção de Bourdieu, obviamente. Porém, como sociólogo, posso dizer que muitas vezes a mensagem sociológica é interpretada de modo que tem como um de seus efeitos a prostração dos indivíduos, a desculpabilização funcionando como desresponsabilização, produzindo sujeitos que agem inteiramente como vítimas de sua própria história.

Com a crítica social dos frankfurtianos não é diferente. Não é raro ver uma leitura que os caracteriza como pessimistas quanto ao futuro. E se acomodando nesse pessimismo, os que os leem assim terminam resignando-se melancolicamente.

Não que seja possível aos sujeitos responderem com amplo raio de ação ao movimento alienado da totalidade social, pois não o é. Há, contudo, alguma possibilidade, mesmo que remota, de resistência - não se pode esquecer-se de algo que Horkheimer disse e que não raro passa despercebido: "o homem ainda é melhor do que o mundo em que vive"244. Isso precisa continuar valendo. E não só a cerebralização da subjetividade, como outras ameaças a isso continuarão a surgir. É preciso produzir respostas, mesmo que tais respostas possam ser resumidas, no fim, a um simples "não!". Dizer "não" é um exercício básico de resistência; saber fazê-lo indica o quanto se é sujeito ao invés de objeto.

Não obstante eu tenha feito uma ressalva quanto ao fato de que os sujeitos se utilizam de diferentes meios para se desincumbirem de si mesmos, haja vista a sua vagueza, a cerebralização não pode deixar de ser encarada como um meio mais reificado do que outros, como um passo adiante na desumanização, o que torna urgente esse debate para o qual espero, humildemente, ter contribuído.

\footnotetext{
${ }^{243}$ BOURDIEU, Pierre. A miséria do mundo. Petrópolis: Vozes, 2012, p. 735.

${ }^{244}$ HORKHEIMER, Max. Eclipse da Razão. São Paulo: Unesp, 2015 [1947], p. 176.
} 


\section{Referências Bibliográficas}

ADORNO, Theodor. Sociedade industrial ou capitalismo tardio? Em: Col. Grandes Cientistas Sociais. Textos escolhidos. São Paulo: Editora Ática, 1986 [1968].

Sobre sujeito e objeto. Em: Palavras e Sinais - modelos críticos 2. Petrópolis: Editora Vozes, 1995 [1969].

Minima Moralia; reflexões sobre a vida lesada. Rio de Janeiro: Azougue, 2008

Dialética negativa. Rio de janeiro: Zahar, 2009 [1966]

Sobre a relação entre sociologia e psicologia. Em: Ensaios sobre psicologia social e psicanálise. São Paulo: UNESP, 2015.

ADORNO, Theodor \& HORKHEIMER, Max. Dialética do esclarecimento. Rio de Janeiro: Jorge Zahar. $2^{\text {a }}$ edição (com alteração da numeração das paginas), 2006 [1947]

(orgs.) Temas básicos da sociologia. São Paulo: Cultrix/ Editora da Universidade de São Paulo, 1973 [1956].

AZIZE, Rogério. A nova ordem cerebral: a concepção de 'pessoa' na difusão neurocientífica. Tese de doutorado em Antropologia Social, Museu Nacional, 2010 .

BOURDIEU, Pierre. A miséria do mundo. Petrópolis: Vozes, 2012.

CHANGEUX, Jean-Pierre. O homem neuronal. Lisboa: Publicações Dom Quixote, 1991.

A verdade, o belo e o bem: uma nova abordagem neuronal. Rio de Janeiro: Civilização Brasileira, 2013. 
CRICK, Francis. Astonishing hypothesis: The scientific search for the soul. New York: Simon and Schuster, 1995.

DAMASIO, Antonio. E o cérebro criou o homem. São Paulo: Companhia das Letras, 2011.

O erro de Descartes. São Paulo: Companhia das Letras, 2012.

DUMIT, Joseph. Picturing Personhood: brains scans and biomedical identity.Princeton: Princeton University Press, 2004.

DUPUY, Jean Pierre.Nas origens das ciências cognitivas. São Paulo: Unesp, 1996.

DURKHEIM, Emile. O suicídio. São Paulo: Martins Fontes, 2000.

EDELMAN, Gerald. Biologia da consciência. Lisboa: Instituto Piaget, 1995.

EHRENBERG, Alain. La Fatigue d'être soi: Dépression et société, Paris: Odile Jacob, 1998. 213, 2009.

O sujeito cerebral. Psicologia Clínica, Rio de Janeiro, vol.21, p.187-

EHRENBERG, Alain; BOTBOL, Michel. Depressão, doença da autonomia. Rio de Janeiro, v. 7, n. 1, p. 143-153, 2004.

FORBES, Jorge. Inconsciente e responsabilidade: psicanálise do século XXI. Barueri: Manole, 2012.

FREIRE-COSTA, Jurandir. O risco de cada um; e outros ensaios. Rio de Janeiro: Garamond, 2007.

FREUD, Sigmund. Projeto para uma psicologia científica. Em: Obras psicológicas completas de Sigmund Freud. Rio de Janeiro: Imago, 1990 [1895]. 
O mal-estar na civilização, novas conferências introdutória sobre psicanálise e outros textos (1930-1936). São Paulo: Companhia das Letras, 2015.

GARDNER, Howard. A nova ciência da mente. São Paulo: Edusp, 1996.

GAZZANIGA, Michael. The social brain: Discovering the networks of the mind. New York: Basic Books, 1985.

The ethical brain: The science of our moral dilemmas. New York: Harper Perennial, 2006.

HERCULANO-HOUZEL, Suzana. Cérebro nosso de cada dia Pílulas de neurociência: para uma vida melhor. Rio de Janeiro: Sextante, 2009.

HORGAN, John. A mente desconhecida: Por que a ciência não consegue replicar, medicar e explicar o cérebro humano. São Paulo: Companhia das Letras, 2002.

HORKHEIMER, Max. Teoria Tradicional e Teoria Crítica. Em: Coleção Os Pensadores, v.48. São Paulo: Abril Cultural, 1975 [1937].

A presente situação da Filosofia Social e as tarefas de um Instituto de Pesquisas Sociais. Praga - Estudos Marxistas, n. 7, São Paulo, Hucitec, 121132, 1999 [1931].

Eclipse da razão. São Paulo: UNESP, 2015 [1947].

IZQUIERDO, Ivan; KAPCZINSKI, Flávio; QUEVEDO, João. Bases biológicas dos transtornos psiquiátricos. Porto Alegre: Artmed, 2011.

LÉVI-STRAUSS, Claude. Jean Jacques Rousseau, fundador das ciências do homem. In: Antropologia estrutural dois. São Paulo: CosacNaify, 2013. 
LECOINTRE, Marisa Russo. Emoção e cognição: uma abordagem científica das emoções. Filosofia e História da Biologia, v. 2, n. 1, p. 337-349, 2007.

LIMA, Rossano Cabral. A cerebralização do autismo: notas preliminares. Em: COUTO, Maria Cristina Ventura e MARTINEZ, Renata Gomes (orgs.). Saúde Mental e Saúde Pública: questões para a agenda da reforma psiquiátrica. NUPPSAM/IPUB/UFRJ, Rio de Janeiro, 2007.

LUCÁKS, Georg. História e consciência de classe: estudos sobre a dialética marxista. São Paulo: Martins Fontes, 2003 [1923].

MARCUSE, Herbert. A obsolescência da psicanálise. Em: Cultura e Sociedade. Vol. 2. Rio de Janeiro: Paz e Terra, 1998 [1965].

MARX, Karl; ENGELS, Friedrich. A ideologia alemã. São Paulo: Editorial Grijalbo, 1977

MATOS, Olgaria C.F. Ulisses e a razão insuficiente: geometria e melancolia. Em: Olgaria Matos, O iluminismo visionário: Benjamin, leitor de Descartes e Kant. São Paulo: Brasiliense, 1993.

ORTEGA, Francisco e VIDAL, Fernando. O sujeito cerebral, Scientific American Brasil, v.52, p.20-20, 2006.

ORTEGA, Francisco e BEZERRA JR., Benilton. O sujeito cerebral, Viver Mente e Cérebro, v.162, p.16-17, 2006.

ORTEGA, Francisco. Neurosciences, neuroculture and cerebral self-help. Interface Comunic., Saude, Educ., v.13, n.31, p.247-60, 2009.

ORTEGA, Francisco. O sujeito cerebral e o movimento da neurodiversidade.Mana, Rio de Janeiro, v. 14, n. 2, p. 477-509, 2008.

PERCHERON, Gérard. Neuromitologias: cérebro, indivíduo, espécie e sociedade. in: VEYNE, Paul et al. Indivíduo e Poder. Lisboa: Edições 70, 1987.

RAMOM Y CAJAL, Santiago. Recollections of my life. Massachussets: MIT Press, 1996 [1917]. 
RIBEIRO, Renato Janine. Da responsabilidade na psicanálise. São Paulo, 1998. Disponível em: <http://www.renatojanine.pro.br>. Acesso em: dezembro de 2014. Disponível também em: <http://psicanaliselacaniana.blogspot.com.br/2012/07/daresponsabilidade-na-psicanalise.html >

Novas fronteiras entre natureza e cultura. Em: ADAUTO, Novaes (org). O Homem- Máquina: a ciência manipula o corpo. São Paulo: Companhia das Letras, 2003.

RIBEIRO, Sidarta. Tempo de cérebro. Revista Estudos Avançados, v.27, n. 77 jan/abr 2013.

ROSE, Nikolas \& ABI-RACHED, Joelle.Neuro: the new brain sciences and the management of the mind. Princeton: Princeton University Press, 2013.

ROUSSEAU, Jean-Jacques. Os devaneios do caminhante solitário. Poro Alegre: L\&PM, 2009.

ROUANET, Sérgio Paulo. O homem máquina hoje. Em: NOVAES, Adauto (org). O Homem-Máquina: a ciência manipula o corpo. São Paulo: Companhia das Letras, 2003.

ROUDINESCO, Elisabeth. Por que a psicanálise? Rio de Janeiro: Zahar,2000.

SOLOMON, Andrew. O demônio do meio-dia: uma anatomia da depressão. São Paulo: Companhia das Letras, 2014.

SPINK, Mary Jane P. Cérebro, self e sociedade: uma conversa com Nikolas Rose. Physis-Revista de Saúde Coletiva, v. 20, n. 1, p. 301-324, 2010.

VARELA, Francisco. Conhecer: as ciências cognitivas, tendências e impasses. Lisboa: Instituto Piaget, s/d.

VIDAL, Fernando. Brainhood, anthropological figure of modernity. History of the Human Sciences, v. 22, n. 1, p. 5-36, 2009. 
VIDAL, Fernando. O sujeito cerebral: um esboço histórico e conceitual. Polis e Psique, V.1, n.1, 169-190, 2011.

WOLFF, Francis. Nossa humanidade: de Aristóteles às neurociências. São Paulo: Unesp, 2012.

\section{Artigos de revistas}

CUMINALE, Natalia. Novas esperanças contra a depressão. Revista Veja. Edição 2297, p.152-159, 28 de novembro de 2012.

DIEGUEZ, Consuelo. Questões mentais: eletrochoque. Revista Piauí. № 21, junho de 2008. Disponível em: <http://piaui.folha.uol.com.br/materia/eletrochoque/> Acesso em: 12 março de 2016.

FIORAVANTI, Carlos. Energia para os neurônios: estimulação elétrica de baixa intensidade amadurece como técnica promissora no tratamento contra a depressão. Revista Pesquisa FAPESP. São Paulo, n. 216, p. 16-21, fevereiro de 2014.

GIANINI, Tatiana. A mente ao vivo e em cores. Revista Veja. Edição 2311, p. 80-86, 6 de março de 2013.

HERCULANO-HOUZEL, Suzana. Segredos. Mente e Cérebro. No 267. Abril de 2015.

MOURA, Mariluce. A biologia sob a consciência. Revista Pesquisa FAPESP. São Paulo, n. 186, p. 10-17, agosto de 2011. 


\section{Jornais e sites}

AUGUSTO, Sérgio. O ano da neurocascata. O Estado de São Paulo. 30 de dezembro de 2012. Disponível em: <http://alias.estadao.com.br/noticias/geral,o-ano-daneurocascata-imp-,978978> Acesso em: 15 maio de 2017.

DUNKER, Christian Ingo Lenz. Políticas de sofrimento. Folha de São Paulo. 06 de outubro de $2017 . \quad$ Disponível em:<http://www1.folha.uol.com.br/opiniao/2017/10/1924752-politicas-desofrimento.shtml> Acesso: 26 novembro de 2017.

HERCULANO-HOUZEL, Suzana. Ganhei minha vida de volta com o Prozac. Folha de São Paulo. 17 de janeiro de 2017. Disponível em: $<$

http://www1.folha.uol.com.br/colunas/suzanaherculanohouzel/2017/01/1850401 -ganhei-minha-vida-de-volta-com-o-prozac.shtml?loggedpaywall>. Acesso em: 22 de novembro de 2017.

SAFATLE, Vladimir. Neurocientista psicopata. Folha de São Paulo. 31 de dezembro de 2013. Disponível em: <http://www1.folha.uol.com.br/colunas/vladimirsafatle/2013/12/1391714neurocientista-psicopata.shtml?loggedpaywall> Acesso em: 22 de novembro de 2017.

VASCONCELOS, Monica. Pesquisador se descobre psicopata ao analisar o próprio cérebro. BBC Brasil. 24 de dezembro de 2013. Disponível em: <http://www.bbc.com/portuguese/noticias/2013/12/131223_psychopath_inside_ mv>. Acesso em: 22 de novembro de 2017.

Descoberta a proteína que pode apagar memória. Disponível em: <http://noticias.terra.com.br/ciencia/interna/0,,OI1842276-EI8147,00.html> Acessado em: 13 de março de 2017. 